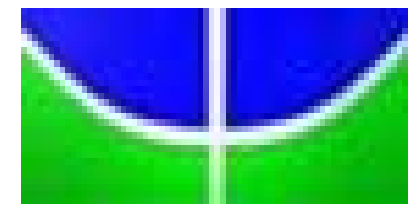

Universidade de Brasília - UNB

Faculdade de Economia, Administração, Contabilidade e Ciência da Informação - FACE Departamento de Ciência da Informação e Documentação - CID

\author{
Mariana Giubertti Guedes \\ Neilia Barros Ferreira
}

A importância da Biblioteca e da Biblioterapia na formação dos internos do Orfanato Lar Rita de Cássia

Brasília 


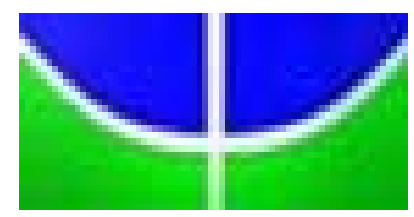

Universidade de Brasília - UNB

Faculdade de Economia, Administração, Contabilidade e Ciência da Informação - FACE Departamento de Ciência da Informação e Documentação - CID

\author{
Mariana Giubertti Guedes \\ Neilia Barros Ferreira
}

\title{
A importância da Biblioteca e da Biblioterapia na formação dos internos do Orfanato Lar Rita de Cássia
}

Monografia apresentada ao Departamento de Ciência da Informação e Documentação como requisito parcial para obtenção do grau de bacharel em Biblioteconomia.

Professora Orientadora: Maria Alice Guimarães Borges

\section{Brasília}


Ferreira, Neilia Barros.

A importância da biblioteca e da biblioterapia na formação dos internos do Orfanato Lar Rita de Cássia / Neilia Barros Ferreira; Mariana Giubertti Guedes. -- Brasília: UnB, 2008.

132 p.: il., color.

Monografia (Graduação) - Universidade de Brasília, Departamento de Ciência da Informação e Documentação, 2008.

Orientadora: Prof ${ }^{\mathrm{a}} \mathrm{Dr}^{\mathrm{a}}$ Maria Alice Guimarães Borges

1. Planejamento de biblioteca. 2. Biblioteca infantil. 3. Biblioteca escolar. 4. Biblioterapia. 5. Processo de ensinoaprendizagem. 6. ONG Sonhar Acordado. 7. Orfanato Lar Rita de Cássia. I. Guedes, Mariana Giubertti.

CDU 021.3:028.02 

À nossa família e amigos, presentes em todos os momentos, e em especial aos internos do Orfanato Lar Rita de Cássia que nos inspiraram. 
Agradecemos a Deus acima de tudo pela paz e sustento.

Aos nossos pais pelo amor, apoio e dedicação.

Aos nossos irmãos pelo carinho.

Aos amigos pelos momentos de alegria.

Aos professores que nos apoiaram e incentivaram durante essa jornada,

Em especial, a Maria Alice que com sua sabedoria, carinho e alegria nos ajudou a tornar esse trabalho uma realidade.

E as voluntárias do Sonhar Acordado por nos permitirem sonhar com elas.

Enfim, a todos aqueles que estiveram ao nosso lado.

Obrigada! 
"Deus é o que me cinge de força e aperfeiçoa o meu caminho" SI 85.32 


\section{Resumo}

Esta monografia tem como resultado final uma proposta para a implantação da Biblioteca Infanto-Juvenil Escolar do Orfanato Lar Rita de Cássia para atender às necessidades informacionais das crianças e adolescentes, utilizando atividades biblioterapêuticas, que proporcionem a melhoria da qualidade de vida. O fundamento teórico aborda o planejamento estratégico, planejamento de bibliotecas, biblioteca infantil, relação da criança e do adolescente com a biblioteca e com a leitura, processo de ensino-aprendizagem, incentivo à leitura, biblioterapia (conceito, tipos e métodos), e aplicação da biblioterapia desenvolvimental em crianças e adolescente que residem em orfanatos. Realiza-se o estudo de caso, mostrando-se o contexto sistêmico de Valparaíso de Goiás, da Organização Não Governamental (ONG) Sonhar Acordado, do Orfanato Lar Rita de Cássia e da sua biblioteca, além de analisar e apresentar o perfil dos seus usuários. A partir do levantamento destes dados, obteve-se um embasamento empírico-científico necessário para elaborar a proposta para a implantação da biblioteca e a inserção de atividades biblioterapêuticas como instrumento para melhorar a qualidade de vida das crianças e adolescentes da instituição, no sentido de, entre outras medidas, promover a inclusão social, digital e informacional.

Palavras-chave: Planejamento estratégico. Planejamento de biblioteca. Biblioteca infantil. Biblioteca escolar. Processo ensino-aprendizagem. Biblioterapia. Biblioterapia Desenvolvimental. Brinquedoteca. Orfanato Lar Rita de Cássia. Valparaíso de Goiás. ONG Sonhar acordado. 


\begin{abstract}
This monographic work has as its end result a proposal for implementation of the Infant and Juvenile School Library at the "Lar Rita de Cássia" Orphanage, to meet the information needs of children and teenagers, using bibliotherapic activities to provide for a better life quality. The theoretical foundation studies include: strategic planning, library planning, children libraries, relationship of children and adolescents with the library and reading, teaching and learning process, reading incentive, bibliotherapy (concept, types and methods), and the application of developmental bibliotherapy for children and adolescents living at orphanages. The case study is done, showing the systemic context of "Valparaiso de Goiás, GO", of the Non Governmental Organization (NGO) "Sonhar Acordado", of the "Lar Rita de Cássia" Orphanage and its library; the library's users profiles are also studied and presented. From the researched data, an empirical scientific basis was developed, as needed for the preparation of the proposal for the development of the library, and the introduction of bibliographic activities as tools to strengthen life quality of the institution's children and adolescents, so that, among other measures, social, digital and informational inclusion could be attained.
\end{abstract}

Keywords: Strategic Planning. Library planning. Children libraries. School Library. Teaching and learning process. Reading incentive. Bibliotherapy. Application of Developmental Bibliotherapy. Toy Library. Lar Rita de Cássia Orphanage. Valparaíso de Goiás. NGO Sonhar Acordado. 


\section{Lista de Figuras}

Figura 1 - Dimensão racional do processo de planejamento 22

Figura 2 - Níveis organizacionais e tipos de planejamento 23

Figura 3 - Enfoque de Planejamento 26

Figura 4 - Esquema hierárquico 26

Figura 5 - Quadro síntese da dinâmica do processo de planejamento 29

Figura 6 - Fatores que afetam a escolha de atividades de

ensino-aprendizagem 59

Figura 7 - As atividades de aprendizagem devem variar segundo os objetivos 59

Figura 8 - Mapa do entorno de Brasília 63

Figura 9 - Curva populacional da Valparaíso de Goiás 65

Figura 10 - População de Valparaíso de Goiás 65

Figura 11 - Número de docentes x Número de alunos $\quad 67$

Figura 12 - Número de escolas x Número de sala $\quad 67$

Figura 13 - Comparação de alunos em diferentes níveis de ensino 68

Figura 14 - Arrecadação do ICMS em Valparaíso de Goiás 73

Figura 15 - Distribuição do ICMS em Valparaíso de Goiás 73

Figura 16 - Moradia x salário mínimo $\quad 76$

Figura 17 - Idade dos voluntários 83

Figura 18 - Local de trabalho voluntário 84

Figura 19 - Orfanato Lar Rita de Cássia 90

Figura 20 - Crianças do Orfanato por sexo 91

Figura 21 - Número de crianças por idade $\quad 91$

Figura 22 - Trabalho voluntário no Orfanato 93

Figura 23 - Entrada da Biblioteca 95

Figura 24 - Acervo da Biblioteca 96

Figura 25 - Idade dos internos 98

Figura 26 - Sexo 98

Figura 27 - Escolaridade $\quad 99$

Figura 28 - Interesse pela leitura $\quad 99$

Figura 29 - Preferência de leitura $\quad 100$

Figura 30 - Tipo de material de leitura $\quad 100$

Figura 31 - Quantidade de livros lidos por criança de até 11 anos 101

Figura 32 - Quantidade de livros lidos por adolescentes de 12 a 18 anos $\quad 101$

Figura 33 - Quantidade de livros lidos por crianças de até 11 anos, 102

Figura 34 - Quantidade de livros lidos por adolescentes de 12 a 18 anos, obrigados pela escola 102

Figura 35 - Biblioteca escolar 103

Figura 36 - Uso da Biblioteca escolar 103

Figura 37 - Biblioteca do Orfanato Lar Rita de Cássia 104

Figura 38 - Atividades principais 104

Figura 39 - Motivo de não utilizar 105

Figura 40 - Acesso a Internet 105

Figura 41 - Interesse em usar a Internet 106

Figura 42 - Sites de interesse 106 


\section{Lista de tabelas}

Tabela 1 - Princípios de eficiência, eficácia e efetividade 23

Tabela 2 - Enfoque de planejamento e o esquema hierárquico 27

Tabela 3 - Biblioteca Nacional: funções 36

Tabela 4 - Conceitos e objetivos da biblioterapia 47

Tabela 5 - Características dos três tipos da biblioterapia 50

Tabela 6 - Taxa geométrica de crescimento de Valparaíso de Goiás 64

Tabela 7 - Educação $\quad 66$

Tabela 8 - Distribuição de alunos em diferentes níveis de ensino 68

Tabela 9 - Efetivo da pecuária 70

Tabela 10 - Produção Agrícola 70

Tabela 11 - Produto Interno Bruto de Valparaíso de Goiás 71

Tabela 12 - Região Integrada de Desenvolvimento do

Distrito Federal e Entorno (RIDE) 72

Tabela 13 - Receita e Despesa de Valparaíso de Goiás 74

Tabela 14 - Saneamento $\quad 75$

Tabela 15 - Índice de Desenvolvimento Humano Municipal de

Tabela 16 - Elaboração do Projeto 109 


\section{Lista de abreviaturas}

AACR2 - Anglo-American Cataloguing Rules (segunda edição) ABNT (NBR) - Associação Brasileira de Normas Técnicas CDU - Classificação Decimal Universal

ICMS - Imposto sobre Circulação de Mercadorias e Serviços IDH - Índice de Desenvolvimento Humano

ONG - Organização não governamental

PCN - Parâmetros Curriculares Nacionais

PIB - Produto Interno Bruto

RIDE - Região Integrada de Desenvolvimento do Distrito Federal e Entorno SEPIN - Superintendência de Estatística, Pesquisa e Informação 


\section{SUMÁRIO}

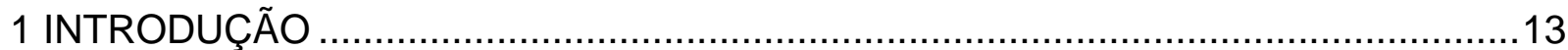

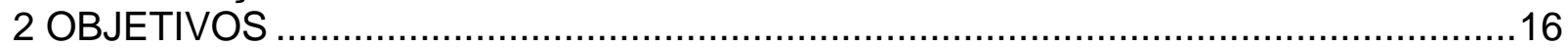

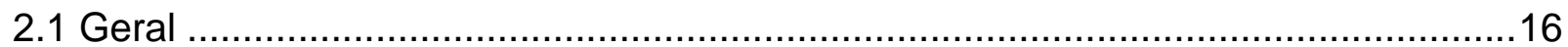

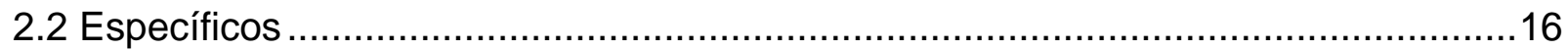

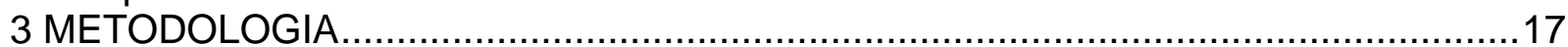

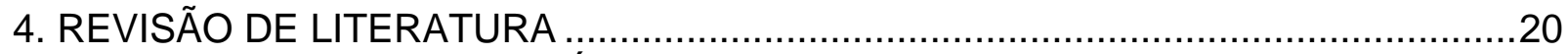

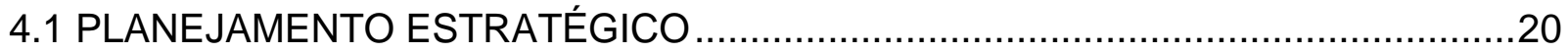

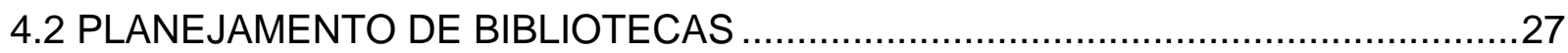

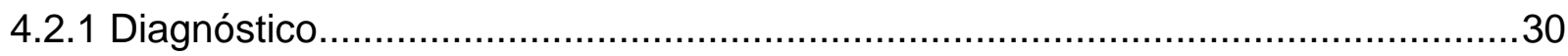

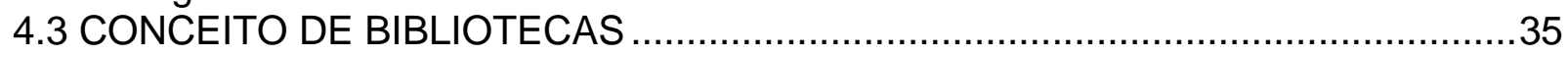

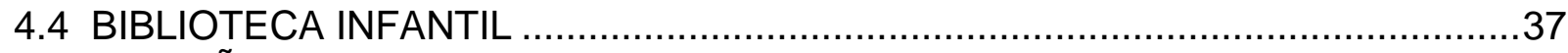

4.5 RELAÇÃO DA CRIANÇA E DO ADOLESCENTE COM A BIBLIOTECA E A

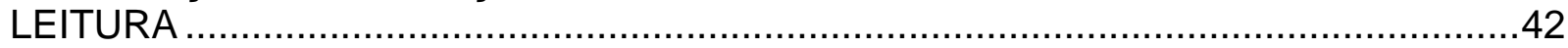

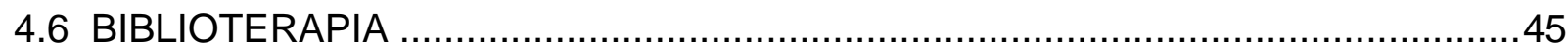

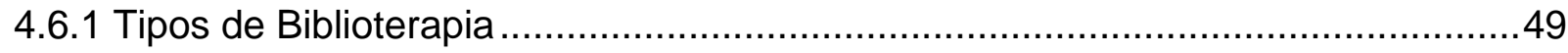

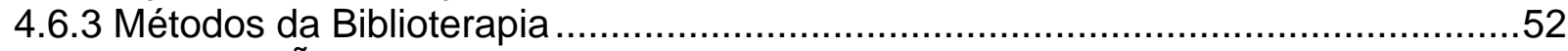

4.7 A APLICAÇÃO DA BIBLIOTERAPIA DESENVOLVIMENTAL EM CRIANÇAS E ADOLESCENTES QUE RESIDEM EM ORFANATOS ........................................... 54 4.8 A BIBLIOTECA ESCOLAR NO PROCESSO DE ENSINO - APRENDIZAGEM ......58 5. ESTUDO DE CASO: Biblioteca Infantil do Orfanato Lar Rita de Cássia ....................62

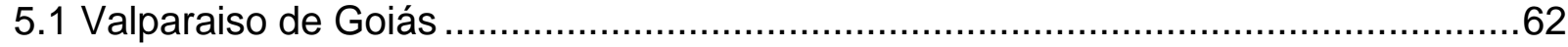

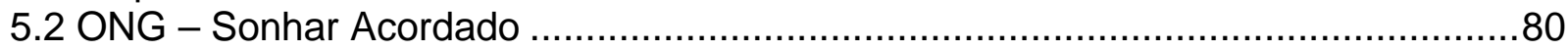

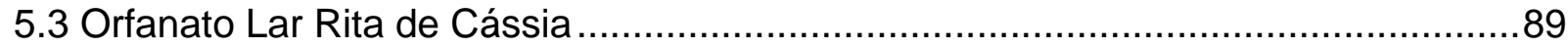

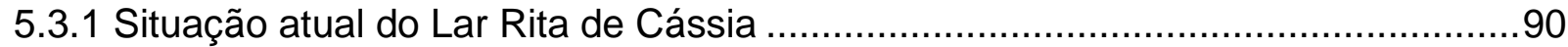

5.3.2 A importância das Doações e dos Voluntários .................................................93

5.4 Biblioteca do Orfanato Lar Rita de Cássia.........................................................94

5.4.1 Relação das Crianças e Adolescentes com a Biblioteca....................................96

5.4.2 Perfil dos usuários da Biblioteca Lar Rita de Cássia ..........................................97

6 PROPOSTA PARA IMPLANTAÇÃO DE UMA BIBLIOTECA NO ORFANATO LAR

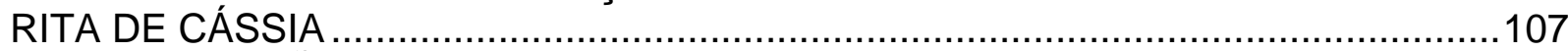

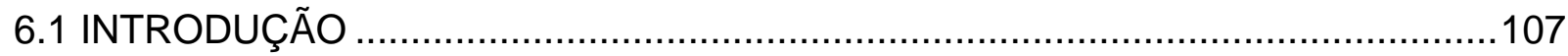

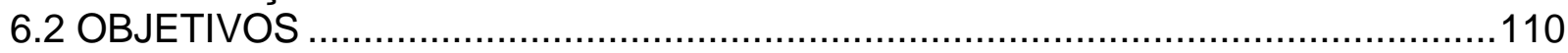

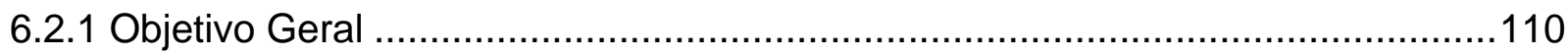

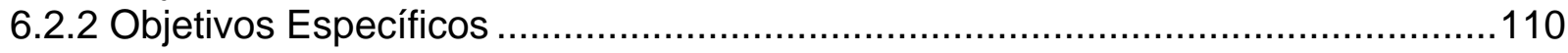

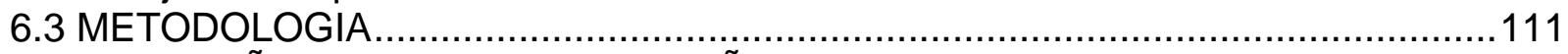

6.4 SUGESTÕES PARA A IMPLANTAÇÃO DA BIBLIOTECA DO ORFANATO LAR

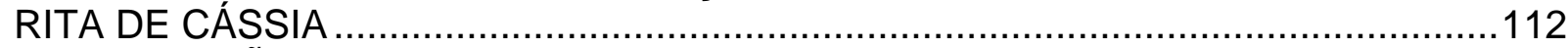

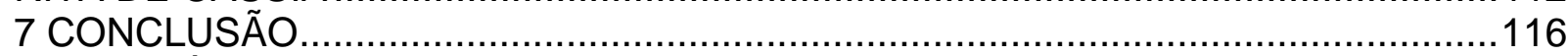

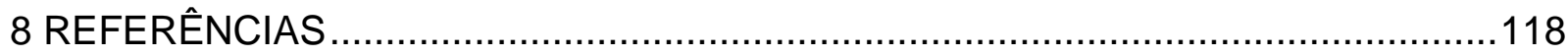

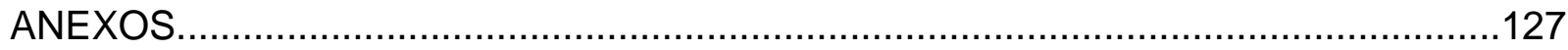




\section{INTRODUÇÃO}

A realidade brasileira, com relação ao uso da leitura pela juventude, é preocupante, pois existe uma deficiência no processo de ensino-aprendizagem de crianças e adolescentes, o que ocasiona um grande número de analfabetos funcionais. A cada dia cresce o número de crianças e adolescentes que passam seu horário livre em frente ao computador, jogando ou visitando sites de relacionamento, raramente se preocupam em buscar informação e quando fazem trabalho escolar usam a Internet como recurso de "copiar" e "colar", quase nem é lido aquilo que copia. Também é muito comum crianças e adolescentes ficarem horas em frente a TV. Em geral, não se vê a juventude brasileira com um livro na mão.

Esta situação pode ser justificada por vários fatores, como por exemplo, a falta de incentivo à leitura pelas escolas; pais que não têm o hábito de ler que possa transmitir aos seus filhos e uma sociedade alienada voltada as mídias. Sabe-se que as crianças e adolescentes aprendem a se relacionar com o livro por intermédio de pais, professores e bibliotecários, entre outros, se estes mediadores não propuserem o livro como forma de entretenimento e crescimento pessoal, estes possíveis leitores passam a condição de não-leitores.

O analfabetismo funcional é a incapacidade de entender aquilo que se lê. A leitura é um processo contínuo de crescimento, onde o leitor a princípio entende as palavras, signos lingüísticos, e após adquirir uma estrutura cognitiva, por meio de estudos e leituras, é capaz de contextualizar diferentes realidades.

A leitura é capaz de criar valores, proporcionar potencial crítico, instigar o interesse do saber e do conhecer, além de levar o leitor a um universo de criatividade. A leitura também tem seu caráter terapêutico que permite ao leitor superar seus conflitos por meio de métodos biblioterapêuticos desenvolvidos por bibliotecários.

A biblioteca infanto-juvenil e a biblioteca escolar têm como função social subsidiar as demandas informacionais das crianças e adolescentes, auxiliar em suas atividades escolares e instigar o interesse pela leitura. 
É cruel a realidade brasileira onde uma pessoa lê as palavras e as reproduz em uma folha de papel, mas é incapaz de discorrer sobre o assunto e muito menos criar um texto com suas próprias palavras. A biblioteca infantil e a biblioteca escolar também fazem parte dessa realidade, onde na maioria dos municípios e nas escolas existe o espaço destinado à biblioteca, mas ela de fato não existe, uma vez que não tem incentivo do governo e muito menos bibliotecários atuando nessa área.

E quando, por sorte, uma biblioteca infantil ou escolar tem um bibliotecário ele preocupa-se muitas vezes, apenas, em catalogar e classificar, o que não se pode condenar, considerando que durante sua graduação pouco foi discutido sobre o papel social do profissional da informação, deixando de lado a função educativa, lúdica e de incentivo à leitura.

As bibliotecas são construídas para atender a um determinado público e forneceIhes informação, criar uma biblioteca é algo que dá status a qualquer governo ou instituição. Mas para fazê-la funcionar de fato é preciso planejar. Assim como uma empresa para ser bem sucedida precisa ser estruturada, aplicar os processos do planejamento e passar por constantes avaliações, a biblioteca também precisa. $O$ planejamento é um processo sistematizado que busca um objetivo, e com a Teoria Geral dos Sistemas é possível ampliar e compreender o processo como um todo, bem como as estratégias que devem ser utilizadas para alcançar os objetivos do projeto.

Os bibliotecários devem aplicar os benefícios do planejamento estratégico em suas instituições, bem como, os processos de planejamento social, pois só assim serão capazes de otimizar seus serviços e criar atividades, que no caso da biblioteca InfantoJuvenil e a Escolar, possam instigar o lado lúdico, promover a inclusão social e digital, criar o hábito de leitura, auxiliar no processo ensino-aprendizagem e melhorar a qualidade de vida de crianças e adolescentes.

Em instituições que trabalham com o desenvolvimento pessoal de crianças e adolescentes, como orfanatos, vê-se que além da necessidade de promover a informação elas precisam atentar-se aos conflitos internos que são resultados de experiências de agressão e abandono. A biblioterapia desenvolvimental tem como fundamento um apoio literário específico para uma mudança de comportamento por meio do autoconhecimento. Este trabalho pode auxiliar a instituição, permitindo que a 
criança e o adolescente obtenham uma realização pessoal a partir do momento em que possam encarar seus problemas e superá-los.

Conhecendo essa situação, e sabendo a necessidade que o Orfanato Lar Rita de Cássia tem em colocar para funcionar sua biblioteca, realizou-se uma revisão de literatura que aborda o planejamento estratégico; planejamento de biblioteca; biblioteca infantil; relação da criança e do adolescente com a biblioteca; biblioterapia e a sua aplicação em crianças que residem em orfanatos, e a biblioteca escolar no processo de ensino-aprendizagem.

Baseado na Teoria Geral dos Sistemas, onde a riqueza de um sistema é determinada pela complexidade das relações entre os elementos, e não pelo número de elementos, realizou-se o estudo de caso onde é apresentada a história e analisado os dados socioeconômicos e outros, da cidade de Valparaíso de Goiás; a história e os projetos da ONG Sonhar Acordado; a história e a situação atual do Orfanato Lar Rita de Cássia e as condições da Biblioteca da instituição.

O somatório da teoria com a experiência prática foi a base empírico-científico necessária para sugerir um projeto de implantação da Biblioteca do Orfanato e com isso atender as demandas psicológicas e educacionais, de lazer e entretenimento das crianças e adolescentes dessa instituição. 


\section{OBJETIVOS}

\subsection{Geral}

Identificar o contexto e as atividades que estão sendo realizadas pelo Orfanato Lar Rita de Cássia tendo em vista o potencial da instituição para disponibilizar aos internos do Orfanato Lar Rita de Cássia o acesso e uso das informações necessárias ao seu desenvolvimento e no enfrentamento dos seus conflitos interiores, além de fomentar o hábito à leitura.

\subsection{Específicos}

- Explicitar a necessidade do planejamento estratégico para as unidades de informação;

- Caracterizar as particularidades da biblioteca infantil e da biblioteca escolar;

- Compreender a relação da criança e do adolescente com a biblioteca e com a leitura;

- Compreender o papel da biblioterapia e seu auxilio no tratamento de problemas psicológicos de crianças e adolescentes;

- Apresentar tipos e métodos biblioterapêuticos;

- Mostrar a aplicação da biblioterapia desenvolvimental em crianças e adolescentes que residem em orfanato;

- Conhecer a ONG Sonhar Acordado;

- Compreender a realidade de Valparaíso de Goiás;

- Entender a estrutura e o funcionamento do Orfanato Lar Rita de Cássia;

- Conhecer o perfil dos usuários da Biblioteca do Orfanato Lar Rita de Cássia;

- Conhecer a Biblioteca do Orfanato Lar Rita de Cássia;

- Realizar uma proposta para implantação da Biblioteca do Orfanato Lar Rita de Cássia. 


\section{METODOLOGIA}

Este documento é constituído de três partes, com suas subdivisões: revisão de literatura, estudo de caso e elaboração da proposta de implantação da Biblioteca do Orfanato Lar Rita de Cássia.

Para realizar a revisão de literatura foram feitas pesquisas em livros, artigos de periódicos, anais de congressos e seminários, e páginas de Internet de assunto relevante para este trabalho. A revisão de literatura aborda os principais temas do documento do ponto de vista que abrange o planejamento estratégico, planejamento de unidades de informação, apresenta conceitos de bibliotecas, aprofunda-se na Biblioteca Infantil e Escolar, que é de suma importância para esta sugestão de projeto, demonstra a relação da criança e adolescente com a Biblioteca, expõe o processo de ensinoaprendizagem. Aprofunda-se na Biblioterapia como instrumento auxiliar na resolução de problemas internos de crianças e adolescentes e seus tipos, processos e métodos. Inclui toda a área de interesse para elaborar um projeto de implantação de uma Biblioteca com uma brinquedoteca Infanto-Juvenil Escolar em um orfanato.

Baseando-se na Teoria Geral dos Sistemas, o estudo de caso deste trabalho buscou apresentar, claramente, a relação entre os sistemas: maior, intermediário e específico. Valparaíso de Goiás, como o sistema maior apresenta sua história, principais características e os dados sociais e econômicos. Os dados foram adquiridos pelo site da Superintendência de Estatística, Pesquisa e Informação (SEPIN), do estado de Goiás. Trabalha-se com dois sistemas intermediários a ONG - Sonhar Acordado e Orfanato Lar Rita de Cássia.

O conteúdo sobre a ONG Sonhar Acordado foi consultado no site Sonhar Acordado - São Paulo, pois o site do trabalho da ONG em Brasília estava fora do ar no período do levantamento dos dados, por isso a maioria das informações fornecidas estão voltadas às atividades realizadas em São Paulo, tendo algumas variações quanto às atividades realizadas em Brasília.

Devido a falta de documentos sobre a história do Lar Rita de Cássia e sua atual situação foi realizada uma entrevista com a administradora do orfanato Pastora Alves 
Custodio Rodrigues, 63 anos, e a voluntária Jase Teixeira Chaves, 44 anos, que acompanha o orfanato a mais de 10 anos.

O método de pesquisa sempre dependerá dos objetivos da pesquisa, e pode ser: método de perguntas, observação e análise documentária. O método de perguntas é dividido em: questionário, entrevista e a técnicas de Delfos. No caso específico do Orfanato Lar Rita de Cássia optou-se pela entrevista que é diferente do questionário, por ser um método de conversa pessoal. De acordo com Bingham e Moore (1959 apud Cunha, 1982), a entrevista pode ser definida como uma conversação séria, cujas finalidades são recolher dados, informar e motivar. Esse método possibilita a captação de emoções e reações às questões que são propostas, pois há um contato direto do entrevistador com o entrevistado e, pelo mesmo motivo é possível que o entrevistado tire possíveis dúvidas que surjam ao longo da entrevista. É importante salientar que a entrevista realizada no orfanato foi estruturada, conforme Anexo A.

Semelhantemente ao orfanato, a biblioteca, sistema específico, encontrava-se sem nenhum tipo de documentação que se pudesse trazer dados para uma análise específica. A partir de um questionário aplicado as bibliotecárias Ana Jesuína Rabelo dos Passos e Suzelayne Estáquio de Azevedo também voluntárias da ONG, foi possível obter maiores informações sobre a instituição (Anexo B).

Para se definir o perfil dos usuários da biblioteca foi aplicado um questionário (Anexo C) em uma amostra de 22 internos, com perguntas abertas e fechadas.

Questionário é o método mais utilizado nos estudos de usuários e consiste numa lista de questões propostas por um pesquisador junto aos respondentes, com o objetivo de obter dados relevantes à pesquisa. Pode ser considerado um método rápido, barato, que consegue atingir uma grande população dispersa numa região extensa e dá liberdade e tempo ao respondente, pois não há constrangimento com a presença de um entrevistador.

A partir dos resultados dos questionários, aplicados nos usuários, foi possível tabular os dados e fazer uma análise qualitativa e quantitativa. A análise quantitativa traz a objetividade dos dados numéricos, reduzindo as distorções interpretativas e abrindo possibilidades para a generalização (adução), teste de hipóteses, corroboração e falseamento de afirmações e teorias por meio das ferramentas oferecidas pela 
estatística e econometria. Já a análise qualitativa busca captar as dimensões subjetivas da ação humana que os dados quantitativos não conseguem captar.

Os estudos quantitativos não permitem a obtenção de dados sobre as necessidades individuais dos usuários. A pesquisa qualitativa dá mais atenção às causas das reações dos usuários da informação e às resoluções dos problemas informacionais, ela dá mais atenção ao lado subjetivo da experiência e do comportamento do homem (BAPTISTA; CUNHA, 2007).

A partir desses dados, que subsidiaram a definição das características e desenho da biblioteca, foi possível a realização da sugestão do projeto de implantação da Biblioteca Infanto-Juvenil Escolar do Orfanato Lar Rita de Cássia, e a aplicação dos métodos biblioterapêuticos. 


\title{
4. REVISÃO DE LITERATURA
}

\subsection{PLANEJAMENTO ESTRATÉGICO}

A informação é o conhecimento registrado capaz de modificar a estrutura cognitiva de um receptor além de conter dados relevantes para a tomada de decisão (BELKIN, 1978; KOCHEN, 1983; LE COADIC, 1996). É o alicerce da geração de conhecimento e por isso é considerada um relevante ativo organizacional e como tal precisa ser gerenciada e controlada (CALAZANS, 2006). A amplitude e a importância da informação para as organizações como afirma Drucker (2003, s.p.) que "a próxima sociedade será uma sociedade do conhecimento, e os trabalhadores do conhecimento serão o grupo dominante da força de trabalho."

\begin{abstract}
Aquele que diminui ou cessa a incorporação contínua de conhecimentos "pára no tempo" e paralisa o movimento ascendente na escala social. Isso também ocorre com as corporações. A desinformação nas empresas elimina a sua capacidade de competição. Por esse motivo, indivíduos e corporações procuram de todas as formas dominar o conhecimento que os torna capazes de obter ganhos. "Informação é poder" foi um lema muito difundido nos tempos em que se tornou claro que o conhecimento acumulado, não é, apenas, uma possibilidade de prazer, mas uma condição básica de sobrevivência. Os mais fortes são aqueles que sabem mais (MILANESI, 2002, p. 54).
\end{abstract}

De acordo com Toffler (1985 apud FURLAN, 1991) a informação é tão importante, talvez até mais, que a terra, o trabalho, o capital e a matéria-prima. A informação está se tornando a mercadoria mais importante da economia contemporânea. Os sistemas de informação podem ajudar as organizações a aperfeiçoar os seus serviços e operações, a aumentar os seus lucros e a melhorar a sua atuação no mercado.

O conceito de organização pode ser definido como um grupamento humano, planejado e organizado, que utiliza a tecnologia disponível no ambiente para alcançar um ou mais objetivos em comum (MORESI, 2001 apud CALAZANS, 2006). O modelo 
teórico destas organizações tem como funções administrativas: planejamento, organização, decisão e controle (CHIAVENATO; SAPIRO, 2004).

No contexto desse documento a função planejar tem grande relevância para com os objetivos propostos. Dentre as várias funções existentes, Spezia (2007) estabelece que planejar é o processo de estabelecer antecipadamente os objetivos e as linhas de ações para alcançar o desejado. De acordo com Furlan (1991), a pessoa que planeja sabe: avaliar as perspectivas a curto, médio e longo prazo; agir sobre o mercado; desenvolver diferenciais competitivos; antecipar situações desfavoráveis; criar participação no mercado e desenvolver produtos adequados.

O planejamento não é um acontecimento, mas um processo contínuo, permanente e dinâmico, que fixa objetivos, define linhas de ação, detalha as etapas para atingi-los e prevê os recursos necessários à consecução desses objetivos. Com a incorporação dessa prática, reduz-se o grau de incerteza dentro da organização, limitam-se ações arbitrárias, diminuem-se riscos ao mesmo tempo em que se dá rentabilidade máxima aos recursos, tira-se proveito de oportunidades, com a melhoria da qualidade de serviços e produtos, e garante-se a realização dos objetivos visados (FURLAN, 1991)

O planejamento é um processo permanente, dinâmico e metodológico de abordagem racional e científica de problemas. Permanente, porque é uma ação contínua sobre um conjunto de variáveis dentro de uma abordagem sistêmica que em determinado momento define as atividades necessárias para atender os problemas, observando tempo, espaço e recursos disponíveis e necessários. Metodológico porque inclui métodos, técnicas e processos ordenados em fases e etapas definidas (BORGES, 2006).

O processo dinâmico do planejamento refere-se a uma seqüência de operações relacionadas ao conhecimento da realidade, tomada de decisão, execução e avaliação. As dimensões do processo de planejamento são definidas como: racional, política, valorativa e técnico administrativa. A dimensão racional é inerente a atividade humana inteligente; a política é a tomada de decisão e a escolha de uma opção a partir das alternativas enquanto que a valorativa está no processo de planejamento onde estão incluídos os valores, idéias, ideais e os padrões éticos de significado pessoal ou 
coletivo da instituição ou comunidade. Já a dimensão técnico administrativa trata da ação que modifica os diferentes níveis ou setores da organização de forma técnica (BAPTISTA, 1981).

O planejamento em seu aspecto racional envolve as ações das pessoas levandoas a planejar, muitas vezes, sem perceber que o estão fazendo (BATISTA, 1981). Para Whitaker (apud BAPTISTA, 1981) as operações racionais do processo de planejamento incluem:

a) reflexão: quando analisa e estuda as informações relacionadas ao dados existentes sobre o objetivo do planejamento;

b) decisão: está relacionada a escolha da opção mais adequada, a partir de alternativas viáveis e compatíveis com a organização;

c) ação: é a execução das decisões;

d) revisão: é a operação crítica dos efeitos da ação planejada, como demonstra a Figura 1:

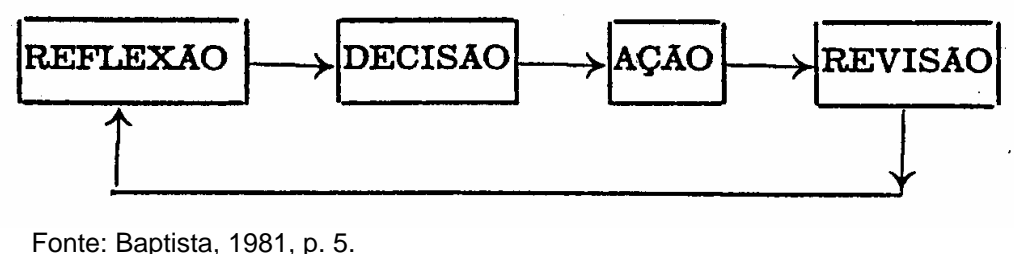

Figura 1 - Dimensão Racional do Processo de Planejamento

A administração tem desenvolvido inúmeras técnicas, para ajudar a aumentar a eficiência das organizações para alcançar com o menor esforço o melhor resultado tático e operacional e assim realizar as atividades da melhor maneira (ALMEIDA, 2005; FISCHMANN, 1991).

Para Chiavenato e Sapiro (2004) o planejamento deve maximizar os resultados e minimizar as deficiências utilizando princípios de maior eficiência, eficácia e efetividade. Eles são os principais critérios de avaliação da gestão, como explicita a Figura 2: 
Tabela 1 - Princípios de eficiência, eficácia e efetividade

\begin{tabular}{|c|c|c|}
\hline Eficiência é & Eficácia é & Efetividade é \\
\hline $\begin{array}{ll}\text { - } & \text { Fazer as coisas da maneira } \\
\text { - } & \text { Resoquada } \\
\text { - } & \text { Cuidar dos recursos } \\
& \text { aplicados } \\
\text { - } & \text { Cumprir o dever } \\
\text { - Reduzir custos }\end{array}$ & $\begin{array}{ll}\text { - } & \text { Fazer as coisas certas } \\
\text { - } & \text { Produzir alternativas } \\
& \text { criativas } \\
& \text { doximinizar a utilização } \\
\text { - } & \text { Obter resursos } \\
\text { - } & \text { Aumentados o lucro }\end{array}$ & $\begin{array}{l}\text { - Manter-se sustentável no } \\
\text { ambiente } \\
\text { Apresentar resultados globais ao } \\
\text { longo do tempo } \\
\text { - Coordenar esforços e energias } \\
\text { sistematicamente }\end{array}$ \\
\hline
\end{tabular}

Para Fischmann e Almeida (1991) a administração de uma organização é realizada em três níveis distintos: estratégico, administrativo e operacional, condicionando desta forma os tipos de planejamento a serem definidos como estratégico, tático e operacional (CHIAVENATO; SAPIRO, 2004). Conforme Figura 3:

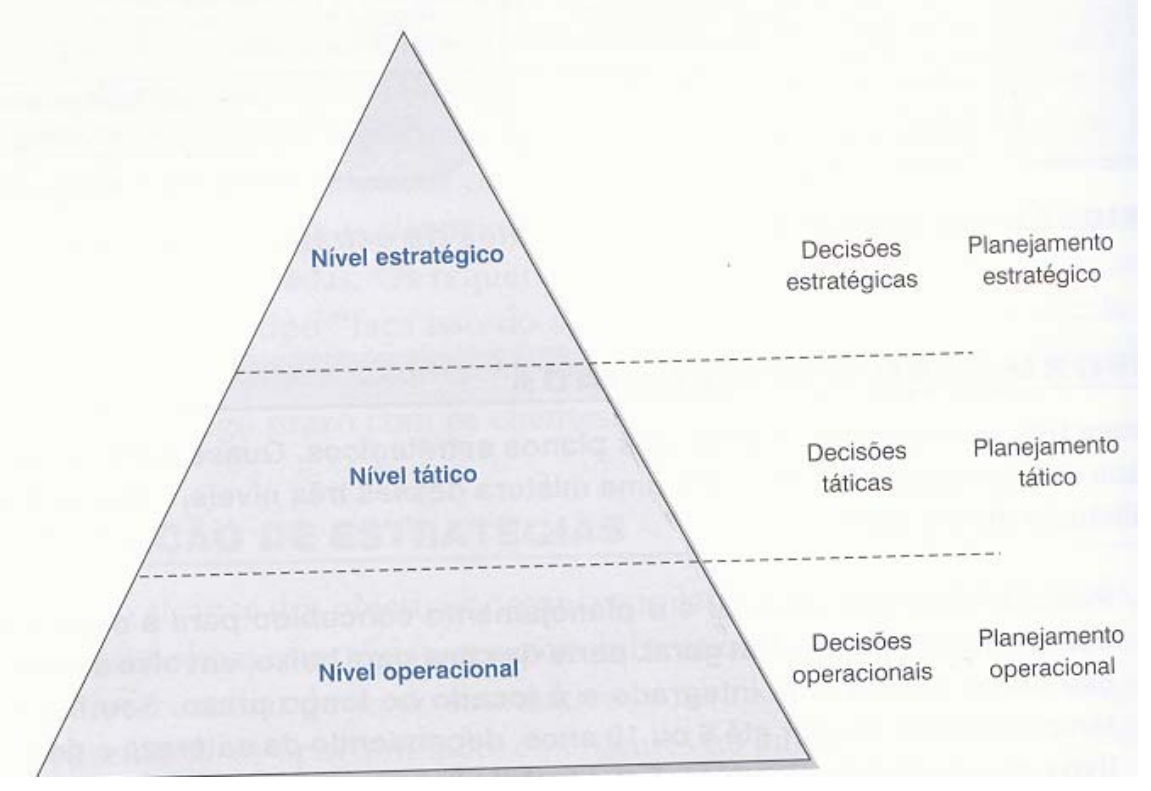

Fonte: CHIAVENATO; SAPIRO, 2004, p.258.

Figura 2 - Níveis organizacionais e tipos de planejamento

O planejamento operacional é direcionado para uma operação ou atividade específica da organização, para execução de ações de curto prazo (CHIAVENATO; SAPIRO, 2004). 
Por outro lado, o planejamento tático é voltado para uma unidade organizacional, subsidiária ou equipe multifuncional. Desenvolve-se a partir dos objetivos definidos pelo planejamento estratégico, com a atuação de médio prazo. Sua finalidade é utilizar de forma eficiente e eficaz os recursos disponíveis para alcançar seus objetivos, ou seja, otimizar determinada área de resultados e não a organização como um todo (CHIAVENATO; SAPIRO, 2004).

Entre os tipos de planejamento o nível estratégico tem maior ênfase, visto que o planejamento estratégico é um processo de formulação de estratégias organizacionais no qual se busca a implementação das ações da organização e de sua missão no ambiente atuante. Ele é relacionado aos objetivos estratégicos de médio e longo prazo que afetam a direção ou a viabilidade da empresa. É no processo de planejamento estratégico que se deve elaborar de forma integrada e articulada os planos táticos e operacionais da instituição (CHIAVENATO; SAPIRO, 2004).

\footnotetext{
Estratégia significa o comportamento global da organização em relação ao ambiente que a circunda. A estratégia é quase sempre uma resposta organizacional às demandas ambientais. Quase sempre os motivos da estratégia estão fora da organização, isto é, no ambiente (CHIAVENATO; SAPIRO, 2004, p. 38).
}

A informação estratégica é um dos elementos da informação organizacional e tem como objetivo principal usar dados, informação e conhecimento para agregar valores a produtos e/ou serviços e a partir disso garantir a sobrevivência da organização aos desafios de hoje. A gestão da informação é a base para a competitividade e deve ser considerada como questão estratégica, pois melhora o retorno dos investimentos a partir dos dados gerenciados e manipulados, auxiliando na redução da incerteza na tomada de decisão, proporcionando a organização escolhas com menor risco e no momento adequado (CALAZANS, 2006).

Quando o planejamento estratégico é aplicado em um Sistema de Informação deve ser um auxiliar no planejamento do uso de seus recursos de forma a suportar os objetivos, desafios e metas estabelecidas (TOFFLER, 1985 apud FURLAN, 1991). Deve conter as funções e os dados necessários para garantir os objetivos, os fatores críticos de sucesso e as necessidades de informação da alta administração da organização (MARTIN, 1986 apud FURLAN, 1991). 
Segundo Martin (1986 apud FURLAN, 1991), são nove os objetivos do Planejamento Estratégico de Sistema de Informação:

1. Investigar as oportunidades de ganho de vantagens competitivas por meio do melhor uso de tecnologias;

2. Estabelecer objetivos e fatores críticos de sucesso para a organização;

3. Facilitar a consecução dos objetivos empresariais por meio da análise de seus fatores críticos de sucesso;

4. Determinar quais informações podem auxiliar a gerência a melhorar seu trabalho;

5. Priorizar a construção de Sistema de Informação em função das necessidades da empresa;

6. Desenvolver um modelo funcional e de dados do negócio;

7. Subdividir o modelo funcional de negócios para uma utilização posterior na fase da Análise da Área de Negócio;

8. Determinar a primeira área de negócio a ser analisada;

9. Permitir a alta administração visualizar o negócio em termos dos objetivos, funções, informações, fatores críticos de sucesso e estrutura organizacional.

O Planejamento Estratégico de Sistema de Informação ocorre a partir da indagação e, consequentemente, da resposta a três perguntas: onde estamos? para onde iremos? e como iremos? A primeira pergunta visa determinar o posicionamento atual da organização na sociedade. A segunda identifica as expectativas dos dirigentes com relação ao futuro da organização, e a última determina os meios e recursos necessários para que a organização atinja os seus objetivos de curto, médio e longo prazo (FURLAN, 1991).

A Figura 3 demonstra os estágios de elaboração de um projeto indicando as fases e subfases que respondem as perguntas: 


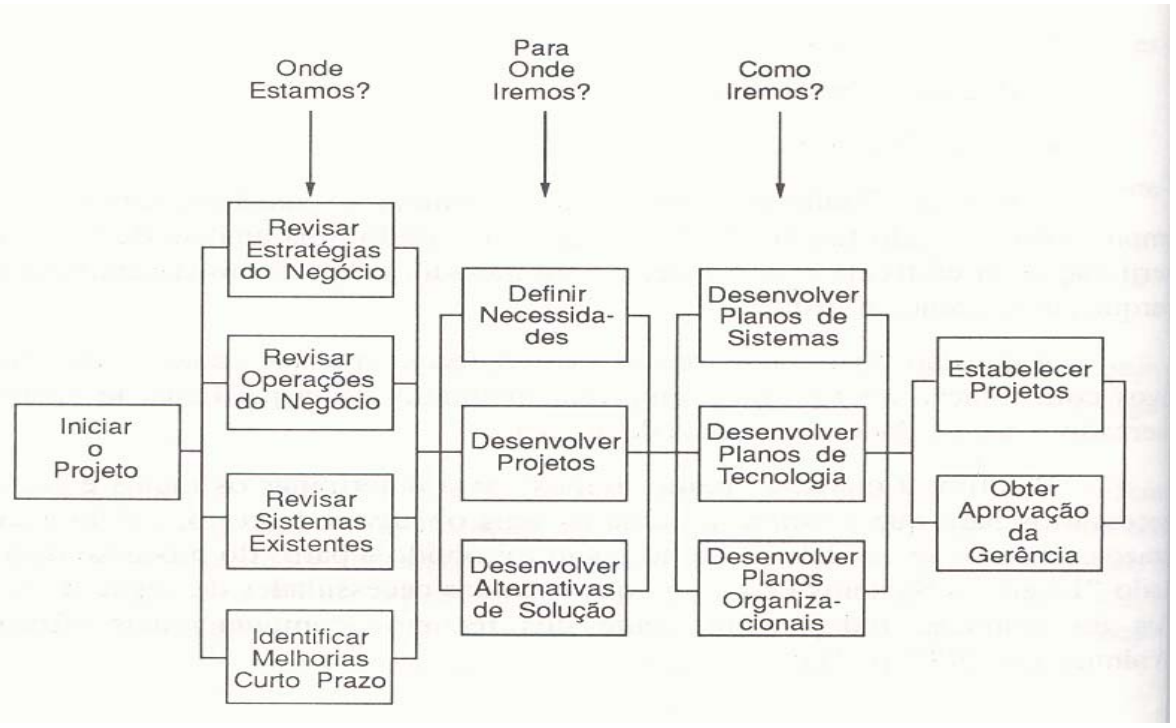

Fonte: FURLAN, 1991, p.10.

Figura 3 - Enfoque de planejamento

Dentro da hierarquia existente nos sistemas, a Figura 4 detalha os níveis que são realizados:

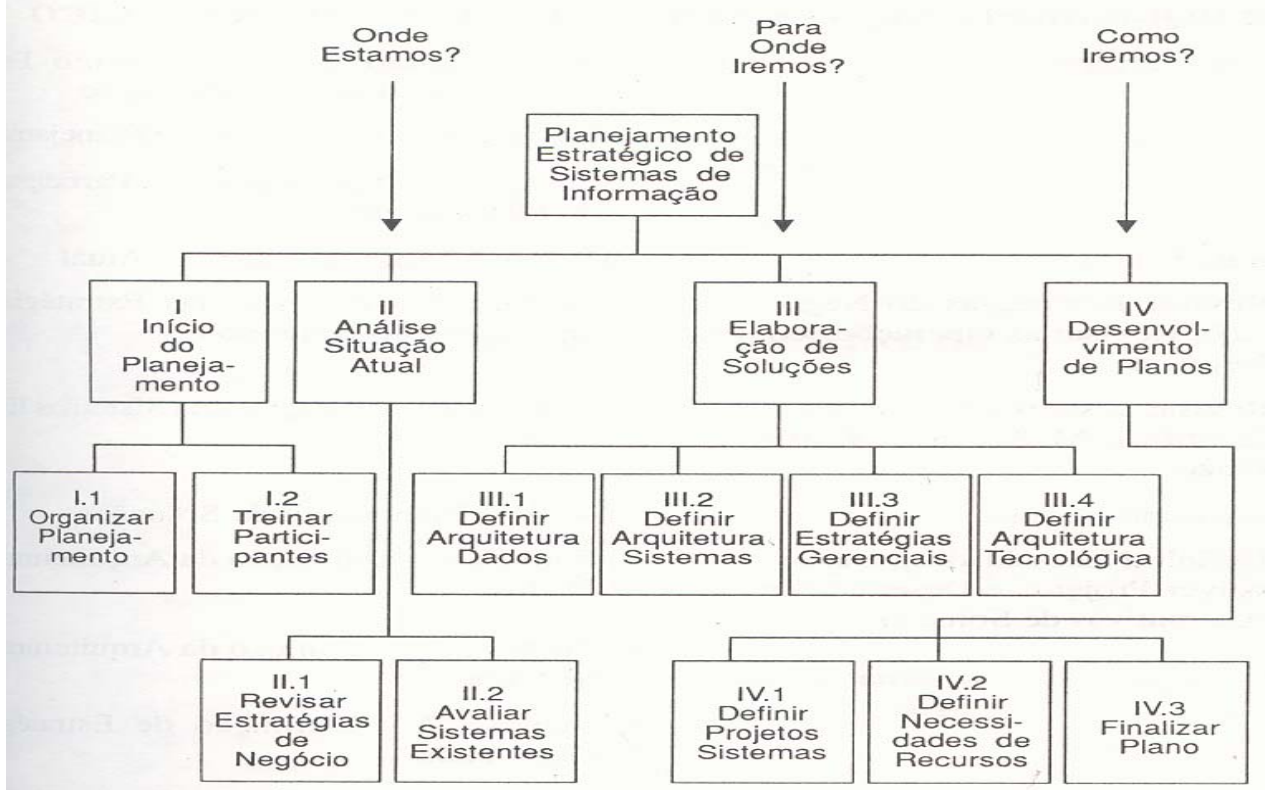

Fonte: FURLAN, 1991, p.11.

Figura 4 - Esquema hierárquico 
Por sua vez, a relação entre o enfoque de planejamento e o esquema hierárquico do planejamento do Sistema de Informação, é detalhada na Tabela 2:

Tabela 2 - Enfoque de planejamento e o esquema hierárquico

\begin{tabular}{|c|c|}
\hline ENFOQUE DE PLANEJAMENTO & ESQUEMA HIERÁRQUICO \\
\hline Iniciar o Projeto & \begin{tabular}{|l} 
Fase I - Início do Planejamento Estratégico de \\
Sistemas de Informação \\
- Subfase 1 - Organização do Planejamento \\
- Subfase 2 - Treinamento dos Participantes do \\
Planejamento
\end{tabular} \\
\hline \begin{tabular}{|l} 
"Onde Estamos" \\
- $\quad$ Revisar Estratégias do Negócio e Revisar as \\
Operações do Negócio \\
- Revisar Sistemas Existentes e Identificar \\
Melhorias de Curto Prazo
\end{tabular} & $\begin{array}{l}\text { Fase II - Análise da Situação Atual } \\
\text { - Subfase } 1 \text { - Revisão das Estratégias e Operações } \\
\text { do Negócio } \\
\text { Subfase } 2 \text { - Avaliação dos Sistemas existentes }\end{array}$ \\
\hline $\begin{array}{l}\text { "Para onde Iremos" } \\
\text { Definir Necessidades, Desenvolver Projetos e } \\
\text { Desenvolver Alternativas de Solução }\end{array}$ & $\begin{array}{ll}\text { Fase III - Elaborações de Soluções } \\
\text { - } \quad \text { Subfase } 1 \text { - Definição da Arquitetura de Dados } \\
\text { - } & \text { Subfase } 2 \text { - Definição da Arquitetura de Sistemas } \\
\text { - } & \text { Subfase } 3 \text { - Definição de Estratégias Gerenciais } \\
\text { - } & \text { Subfase } 4 \text { - Definição da Arquitetura Tecnológica } \\
\end{array}$ \\
\hline $\begin{array}{l}\text {-Como Iremos" } \\
\text { - Desenvolver Planos de Sistemas e Estabelecer } \\
\text { Projetos } \\
\text { Desenvolver Planos de tecnologia } \\
\text { Desenvolver Planos Organizacionais } \\
\text { Obter Aprovação da Gerência }\end{array}$ & $\begin{array}{l}\text { Fase IV - Desenvolvimento de Planos } \\
\text { Subfase } 1 \text { - Desenvolvimento de Projetos de Sistemas } \\
\text { de Informação } \\
\text { Subfase } 2 \text { - Definição das Necessidades de Recursos } \\
\text { Subfase } 3 \text { - Finalização do Plano }\end{array}$ \\
\hline
\end{tabular}

Após e durante esses processos o planejamento estratégico de Sistema de Informação facilita o direcionamento de alto nível dos Sistemas de Informação, de forma a suportar os objetivos, os input para avaliação e mudanças, e possibilita maximizar o retorno de investimento nessas unidades, com maior eficácia e eficiência organizacional (FURLAN, 1991).

\subsection{PLANEJAMENTO DE BIBLIOTECAS}

A administração e suas funções, em especial o planejamento, são processos inter-relacionados de várias áreas do conhecimento e não é diferente com a biblioteconomia. A argumentação de que essa metodologia economiza tempo, faz com 
que o bibliotecário passe a entender que o tempo empregado no processo de planejamento é menor e mais produtivo do que o tempo perdido com processos improvisados e que o planejamento traz vantagens que geram benefícios para a organização, aproveita de forma eficaz as oportunidades que surgem, reduz ricos e também possibilita estabilidade para a organização, conseqüentemente, formando um ambiente mais equilibrado e produtivo (ALMEIDA, 2005).

Todas as instituições têm demandas e necessidades. Muitas vezes a biblioteca precisa criar um projeto para melhorar seu atendimento, sua estrutura física, seus serviços. Quando a biblioteca ainda não existe, é apenas um ideal de um administrador, é essencial elaborar um projeto para sua criação e implantação (ALMEIDA, 2005; MILANESI, 2003), iniciando-se pelo conhecimento da comunidade onde estará inserida. De acordo com Almeida (2005, p. 94):

\footnotetext{
Em determinado município deve levar em conta a quantidade e o perfil de seus públicos, considerando aspectos como distribuição demográfica por faixas etárias, nível de escolaridade, ocupações profissionais, uso de tempo livre e as condições gerais de vida no município.
}

Quanto aos especialistas que trabalham com as tendências das bibliotecas públicas, o futuro e o sucesso da instituição dependem basicamente da sua capacidade de interagir com a comunidade (SUAIDEN, 1997).

De acordo com Milanesi (2003) os centros culturais nascem da coragem dos administradores de priorizar a construção de um prédio cultural, no lugar de tampar buracos de uma estrada ou atender a outras necessidades de um município, associando sua administração a essa obra, pois, um centro cultural melhora o status do dirigente e do um município ou comunidade.

Quanto à prática de criar projetos, organizar e planejar unidades de informação

[...] o primeiro passo e, sem dúvida, dos mais importantes, é a realização do planejamento estratégico e operacional da unidade de informação. A estrutura de trabalho e produção a ser montada e continuamente aprimorado deverá sempre refletir a missão, a estratégia e os objetivos definidos em função da realidade do mercado (BARRETO, 1997, p. 114).

A elaboração de um projeto é um processo dinâmico, com uma sucessão de fases, nem sempre como um caminho linear. Elas fazem parte do ciclo do planejamento 
e suas principais fases, segundo Almeida (2005) são: elaboração ou preparação do projeto, estruturação, desenvolvimento e avaliação.

Essas fases são apresentadas em seqüência lógica, contínua e dinâmica, mas na prática o processo tem se apresentado descontínuo, em grande número de casos, e metodologicamente, o planejador muitas vezes trabalha simultaneamente em diferentes fases, uma vez que se interagem de forma dinâmica. (BATISTA, 1981).

O planejamento de uma unidade de informação só obtém sucesso quando seu processo dinâmico é bem feito. Conforme Figura 5 de Baptista (1981, p. 21) a dinâmica do processo de planejamento social é o resultado de quatro operações do processo racional, ou seja: reflexão, decisão, ação e revisão:

\begin{tabular}{|c|c|c|c|c|}
\hline $\begin{array}{l}\text { Operaçōes do Pro- } \\
\text { cesso Racional (1) }\end{array}$ & $\begin{array}{l}\text { Fases Proces- } \\
\text { suais (2) }\end{array}$ & Fases Metodologicas & Raciocintos (3) & $\begin{array}{l}\text { Documentaça } \\
\text { Decorrente }\end{array}$ \\
\hline \multirow[t]{3}{*}{ Reflexăo } & Sincrese & Escolha e Delimitação do Objeto & $\begin{array}{l}\text { Objetivo } \\
\text { Integrante }\end{array}$ & $\begin{array}{l}\text { Proposta } \\
\text { Preliminar }\end{array}$ \\
\hline & Análise e Síntese & $\begin{array}{l}\text { Estudo/Diagnóstico: } \\
\text { - coleta, seleçäo e processamen. } \\
\text { to de dados; } \\
\text { - estabelecimento de prioridades. }\end{array}$ & $\begin{array}{l}\text { Objetivo } \\
\text { Analítico } \\
\text { Integrante } \\
\text { Projetante }\end{array}$ & Diagnósticos \\
\hline & Criação & $\begin{array}{l}\text { Formulação de Proposições Alter- } \\
\text { nativas de Intervenção }\end{array}$ & $\begin{array}{l}\text { Objetivo } \\
\text { Utópico } \\
\text { Estético }\end{array}$ & $\begin{array}{l}\text { Estudos de } \\
\text { Vlabilidade } \\
\text { Anteprojetos }\end{array}$ \\
\hline Decisăo & Opção & $\begin{array}{l}\text { Escolha de Prioridades } \\
\text { Escolha de Alternativas } \\
\text { Definição de Objetivos e Metas }\end{array}$ & $\begin{array}{l}\text { Objetivo } \\
\text { Experimental } \\
\text { Utópico } \\
\text { Estético }\end{array}$ & $\begin{array}{l}\text { Planos } \\
\text { Programas } \\
\text { Projetos }\end{array}$ \\
\hline Açăم . & Intervenção & $\begin{array}{l}\text { Implementaçäo } \\
\text { Implantação execução } \\
\text { Controle }\end{array}$ & $\begin{array}{l}\text { Objetivo } \\
\text { Experimental } \\
\text { Estético }\end{array}$ & $\begin{array}{l}\text { Roteiros } \\
\text { Normas } \\
\text { Manuaís } \\
\text { Relatórios }\end{array}$ \\
\hline Revlsăم & Critica & $\begin{array}{l}\text { Avaliação } \\
\text { "Feed-Back" (Retorno) }\end{array}$ & $\begin{array}{l}\text { Objetivo } \\
\text { Analítico } \\
\text { Projetante }\end{array}$ & $\begin{array}{l}\text { Relatórios } \\
\text { Avaliativos }\end{array}$ \\
\hline \multicolumn{5}{|c|}{$\begin{array}{l}\text { (1) F. W. FERREIRA, op. cit. } \\
\text { (2) Com base nos autores: } \\
\text { C. LAMPARELII, Uma Contributçāo } \\
\text { M. T. GODINHO, Discussoes Sobre } \\
\text { (8) J. FRIEDMANN, op. cit. }\end{array}$} \\
\hline
\end{tabular}

Figura 5 - Quadro síntese da dinâmica do processo de planejamento

A reflexão é o momento de definir o elemento que será objeto do processo e conhecer a realidade da instituição. Inicia-se com a síncrese que é um processo capaz de reunir vários pensamentos e criar o novo, ou seja, é a fusão de vários conceitos e experiências para se chegar a um objetivo e delimitar um objeto. Com o objeto definido 
é necessário que seja feita a sua análise e síntese, que é a etapa de contextualização da unidade de informação em seu Sistema Maior, Intermediário e Específico. É durante a criação que se propõem as alternativas para a intervenção na unidade de informação. Esta fase é utópica, estética e objetiva. O resultado da reflexão é o diagnóstico.

A decisão é a escolha da opção entre várias alternativas apresentadas, bem como o estabelecimento das prioridades, propostas, objetivos e metas, que se constituirão no projeto. Ele é o resultado de uma ação programada, concretizada na elaboração de planos, programas ou projetos.

A ação é a intervenção que deverá ser executada, constando da implementação e reúne os recursos necessários para que possa acontecer a implantação do projeto, com o estabelecimento de normas, manuais e relatórios. A última operação é a revisão crítica da ação por meio do acompanhamento, controle e avaliação, faz parte da revisão juntamente com o feedback que é o retorno dos efeitos do projeto, sejam eles corretos ou com algum desvio, necessitando de ajustes.

\subsubsection{Diagnóstico}

Após a proposta preliminar, a elaboração do diagnóstico é a etapa seguinte. Ele possibilitará a unidade de informação conhecer o estado atual em que se encontra e buscar diminuir a distância entre a situação existente e a desejada além de avaliar o grau de satisfação do usuário (ALMEIDA, 2005).

O diagnóstico "é uma análise do passado para justificar as decisões para o futuro" (HOLANDA, 1982). O diagnóstico empresarial/organizacional é um instrumento utilizado para se fazer o mapeamento da situação global da organização, de acordo com a visão de seus proprietários ou dirigentes, funcionários, clientes internos e externos, como etapa anterior a elaboração do plano, programa ou projeto (QUEIROZ et al., 2005). Ele analisa e indica as potencialidades da organização, considerando suas fortalezas e forças, de um lado, e suas fragilidades e fraquezas de outro (CHIAVENATO; SAPIRO, 2004), além das oportunidades e desafios.

Quando este instrumento é voltado para uma biblioteca, 
vem a ser, numa primeira etapa, o levantamento minucioso de dados sobre a sua estrutura administrativa, serviços que executa e oferece, recursos humanos e materiais de que dispõe, instalações físicas e satisfação da clientela; numa segunda etapa, contextualização dos dados, a determinação das causas que levaram a biblioteca a estado de inoperância (MACIEL, 1993, p. 21).

As etapas para se fazer um diagnóstico são: preparação, elaboração do projeto do diagnóstico e sua implantação (ALMEIDA, 2005).

É na etapa de preparação do diagnóstico que se analisa os objetivos da unidade de informação, identificam-se os aspectos a serem avaliados, define-se a equipe que deverá liderar o processo e faz-se a revisão de literatura (ALMEIDA, 2005), traçando, dessa maneira, o cenário organizacional.

A elaboração do projeto de diagnóstico contém os objetivos a serem alcançados, o problema ou as questões que o motivaram, as hipóteses de trabalho, a metodologia a ser utilizada para a coleta de dados, as medidas de desempenho ou os indicadores de avaliação adotados e o cronograma do processo (ALMEIDA, 2005). Nessa fase o diagnóstico utiliza o questionário ou a entrevista como instrumento para levantar os dados e opiniões dos funcionários ou usuários, obtendo os pontos fortes e fracos da organização a fim de solucionar os problemas, sobre questões abrangentes, tais como a prática do planejamento e da gestão, a estrutura organizacional e seu funcionamento, os recursos humanos, os sistemas de comunicação e informatização existentes, a visão estratégica da organização, além de pesquisar as percepções e expectativas dos principais clientes externos quanto ao seu relacionamento com a empresa (QUEIROZ et al., 2005).

Durante a implantação defini-se o cronograma, fluxograma, a tarefa de cada membro, o coordenador da equipe e os recursos que serão necessários para a realização do diagnóstico (ALMEIDA, 2005).

O diagnóstico é capaz de possibilitar ao bibliotecário o direcionamento do seu trabalho, pois indicará, especificamente, a situação atual dos setores tanto dos que estão bem organizados como dos que apresentam deficiências, evitando um esforço por vezes desnecessário (MACIEL, 1993). 


\title{
4.2.2 Projeto
}

A elaboração do projeto tem como finalidade apresentar soluções para os problemas apresentados no diagnóstico, acompanhados de justificativas, que procurem enfatizar o impacto do projeto, a vantagem estratégica que poderá trazer e os seus benefícios sociais (ALMEIDA, 2005).

De acordo com Vanim e Faqueti (2004, p. 2):

\begin{abstract}
Um projeto surge em resposta a um problema concreto. Elaborar um projeto é, antes de mais nada, contribuir para a solução de problemas, transformando IDEIAS em AÇÕES. O documento chamado projeto é o resultado obtido ao se "projetar" no papel tudo o que é necessário para o desenvolvimento de um conjunto de atividades a serem executadas: quais são os objetivos, que meios serão buscados para atingi-los, quais recursos serão necessários, onde serão obtidos e como serão avaliados os resultados.
\end{abstract}

Os objetivos precisam atender as necessidades da instituição. É essencial que os objetivos da biblioteca sejam pensados em relação à instituição a que pertence e à comunidade a que serve, ou seja, eles devem ser definidos de acordo com a missão da instituição e buscar características como: coerência, aceitabilidade, exeqüibilidade, motivação e simplicidade (ALMEIDA, 2005). E seu detalhamento deve responder as questões: Para que? e Para quem? (VANIM; FAQUETI, 2004).

As metas devem ser estabelecidas a partir dos objetivos, pois elas são a quantificação deles, seja em números, índices, tempo, enfim respondendo a questão: Quanto?

Em um projeto é importante descrever a metodologia, detalhando as etapas, bem como os métodos, técnicas e processos a serem adotados para se cumprir cada uma delas, além de definir o fluxo de trabalho e o cronograma, os recursos organizacionais, físicos, humanos, materiais, tanto o material de consumo, como o material permanente, a previsão de custos, o acompanhamento e a avaliação (ALMEIDA, 2000). Conforme representadas na Figura 4 e na Tabela 2.

Em sintonia com o ponto de vista, e a relevância, a metodologia do projeto, segundo Vanim e Faqueti (2004), descreve a especificação da mesma, respondendo as 
questões: Como? Com que? Onde? É a metodologia que vai dar aos avaliadores a certeza de que os objetivos do projeto realmente têm condições de serem atingidos.

Os recursos para a implantação de um projeto são fundamentais, mesmo que não sejam, necessariamente, financeiros. Estes recursos são instrumentos capazes de desenvolver o projeto. Os diversos tipos de recursos são: institucional, organizacional, humano, material e físico (ALMEIDA, 2005).

O recurso institucional detalha as mudanças necessárias para adequar os instrumentos legais em vigor às demandas do projeto. O recurso organizacional referese à estrutura organizacional adequada ao desenvolvimento do projeto (ALMEIDA, 2005).

Os recursos humanos referem-se às pessoas responsáveis e participantes do desenvolvimento do projeto, que podem ser contratadas especialmente para isso, como também podem ser funcionários da organização, consultores ou voluntários.

Os recursos materiais devem ser discriminados na fase de elaboração do projeto e especificados dentro da categoria de material de consumo ou material permanente. Material de consumo é o bem não-patrimonial, por exemplo, o material de escritório. Enquanto o material permanente faz parte do patrimônio da organização, como por exemplo, o mobiliário e computadores (ALMEIDA, 2005).

O recurso físico corresponde à área, o espaço destinado para a implantação do projeto. Caso seja necessário reforma, ampliação, adequação ou novo layout, ele deve estar incluído no projeto. Também deve ser planejado a definição do mobiliário a partir do espaço físico existente.

A criação de uma biblioteca deve partir de um modelo conceitual, que dê subsídios e possibilite planejar a estrutura organizacional, bem como o planejamento do espaço físico, para que num futuro próximo não tenha falta de espaço para o desenvolvimento da coleção, para acomodar os funcionários e atender aos usuários (ALMEIDA, 2005).

A falta de espaço na biblioteca é de solução demorada, por isso é importante detectar esse problema antes que se torne crítico. As recomendações internacionais para centros de informações estabelecem a necessidade de deixar $20 \%$ do espaço das estantes desocupado, para permitir a inserção de novos materiais. Quando este espaço 
for ocupado é essencial replanejar o espaço, sendo relevante que o crescimento da coleção seja monitorado pelo bibliotecário (ALMEIDA, 2005).

Reconhecidamente, o espaço físico e o mobiliário de uma unidade de informação devem ser preservados, pois a preservação é um fator essencial que deve ser analisado na elaboração do projeto, visto que é melhor incorporar questões relativas à preservação no programa de construção da biblioteca do que investir em soluções paliativas, depois dos serviços serem instalados no novo edifício (ALMEIDA, 2005). A preservação deve ser uma preocupação constante do bibliotecário a fim de evitar a deterioração do acervo. Para isso o bibliotecário precisará de conhecimento básico sobre as condições de armazenamento, exposição e segurança da coleção. É importante saber que os fatores que danificam grande parte dos acervos são: temperatura; umidade relativa; iluminação; poluição atmosférica; agentes biodeterioradores e ação do homem (SILVA FILHO, 200?).

Quanto ao mobiliário, por ter um uso intensivo, é muito importante que seja resistente. Ele só é apreciado e respeitado enquanto estiver em bom estado, seu processo de degradação quando começa cresce rapidamente (GASCUEL, 1987). Por isso é fundamental que o mobiliário para armazenamento do acervo seja planejado em função do tipo e da qualidade de materiais, bem como do tipo de acesso a ser oferecido. É possível observar que o uso de madeira não é recomendável para armazenar coleções e que as estantes de metais com revestimento de esmalte cozido de alta qualidade é a melhor opção para estantes e armários. O piso deve ser bonito e silencioso, além de não favorecer a infestação de insetos, ser impermeável e resistente (ALMEIDA, 2005).O site IG Educação (2008) mostra a relação entre o espaço de uma biblioteca e seu mobiliário:

Diferentemente de um depósito de livros, uma biblioteca deve ser atrativa para o público [...] O espaço e a disposição interna dos móveis e do acervo devem levar em conta os objetivos da biblioteca. É importante que seja um local aconchegante, atrativo e agradável, com entrada independente, de fácil acesso e sem barulho.

A mesma visão de aconchego e conforto é mostrada por Gascuel (1987, p. 42):

A imaginação dos decoradores, dos bibliotecários e dos fornecedores de mobiliário criou formas inesperadas e divertidas: a cobra de espuma, em cujos anéis se pode ler deitado, o banco em forma de cão comprido, os assentos 
agrupados em forma de comboio, ou de uma grande arena de um picadeiro [...] as investigações que partiram do prazer de ler em si mesmo e estudaram o mobiliário que melhor se adapta a esse prazer: ler deitado, ler escondido, ler empoleirado são atitudes naturais para os jovens leitores, porque elas associam o prazer de ler ao bem-estar físico.

Torna-se, portanto, necessário conhecer o público, ou seja, o perfil do usuário como um fator relevante. Deve-se levantar o tipo de público e suas necessidades como as crianças, que requerem mobiliário especial tanto para o acervo quanto para sua acomodação, as características dos diversos públicos, tipo de atividades, características de personalidade, tempo médio de permanência nas áreas de consulta que influenciará no tipo de mobiliário (ALMEIDA, 2005).

Depois de realizados os estágios de elaboração, estruturação e implantação do projeto é fundamental que o bibliotecário receba um Feedback, ou seja, a retroalimentação dos seus usuários, pois, "é uma ferramenta que auxilia o bibliotecário a alcançar eficácia e eficiência organizacional e a desenvolver estratégias para melhorar a eficácia e a eficiência do acervo e dos serviços e produtos" (ALMEIDA, 2005 p.14). É uma das funções principais do processo e visa transformar e integrar os participantes, por meio da ampliação de suas perspectivas" (GOMES et al., 2005).

\subsection{CONCEITO DE BIBLIOTECAS}

A biblioteca é a mais antiga e freqüente instituição identificada com a Educação e a Cultura. Desde que o homem passou a registrar o conhecimento ela persistiu, colecionando e ordenando tabuinhas de argila, papiros, pergaminhos e papéis impressos e está presente na história e nas tradições da humanidade (MILANESI, 2003).

Existem diversos tipos de bibliotecas, com serviços semelhantes, porém cada uma é definida pelo seu público e por suas necessidades. No caso da Biblioteca Nacional ela deve desempenhar a preservação do patrimônio cultural e fomentar à criação de bibliotecas públicas e o controle bibliográfico nacional (CAMPELLO, 2006). Tem a responsabilidade de controlar o depósito legal e de produzir a bibliografia nacional (UNESCO, 1997 apud CAMPELLO, 2006). As três funções: depositária, de 
infra-estrutura e a de serviço nacional abrangente encontram orientações distintas (CAMPELLO, 2006), como pode ser observada na Tabela 3:

Tabela 3 - Biblioteca Nacional: funções

\begin{tabular}{|c|c|c|c|c|}
\hline \begin{tabular}{|l} 
Dimensões \\
conceito \\
biblioteca naciona \\
\end{tabular} & $\begin{array}{l}\text { do Estágio } \\
\text { daldesenvolvimento } \\
\text { al }\end{array}$ & de Usuários principais & Ênfase & $\begin{array}{l}\text { Tipo de Biblioteca } \\
\text { Nacional }\end{array}$ \\
\hline $\begin{array}{l}\text { Depositária } \\
\text { herança cultural } \\
\text { país }\end{array}$ & $\begin{array}{l}\text { daClássico } \\
\text { do(países } \\
\text { desenvolvidos) }\end{array}$ & $\begin{array}{l}\text { Pesquisadores, } \\
\text { acadêmicos }\end{array}$ & Acervo & $\begin{array}{l}\text { Convencional } \\
\text { tradicional }\end{array}$ \\
\hline Infra - estrutura & $\begin{array}{l}\text { Moderno (país } \\
\text { desenvolvidos) }\end{array}$ & ses Bibliotecas & Liderança nacional & Moderna \\
\hline $\begin{array}{l}\text { Serviço nacion } \\
\text { abrangente }\end{array}$ & $\begin{array}{l}\text { nal|Países } \\
\text { desenvolvimento }\end{array}$ & emPopulação & $\begin{array}{l}\text { Serviço para } \\
\text { usuários finais }\end{array}$ & $\begin{array}{l}\text { Serviço nacional de } \\
\text { biblioteca }\end{array}$ \\
\hline
\end{tabular}

Fonte: CAMPELLO, 2006, p. 27

Enquanto a Biblioteca Pública é totalmente aberta à população, comum a todos os cidadãos e destinada à coletividade, as demais bibliotecas, ao contrário, tem uma comunidade específica a atender (FUNDAÇÃO BIBLIOTECA NACIONAL, 1995). Sua principal função é a formação da consciência do cidadão, para que ele possa compreender seus direitos e deveres. Independente das ações e diretrizes governamentais. A biblioteca deve manter sua preocupação com suas funções sociais, que se resumem em função social/comunitária, função informativo-utilitária e função educativa (TARAPANOFF; SUAIDEN, 1995). A verdadeira biblioteca pública tem quatro funções básicas que são: educativa, cultural, recreativa e informacional (ARRUDA, 2000).

A biblioteca pública, como centro cultural, não encontra resistência na sociedade que reconhece a necessidade de seu uso pelas crianças, formando o hábito da leitura. Os administradores não ousam diminuí-la, pois estariam a favor da ignorância e contra a cultura, mas não os impede de colocar a biblioteca à margem da sua política administrativa (MILANESI, 2003).

A biblioteca escolar é um complemento da escola, pois acompanha o processo de ensino-aprendizagem do aluno. Diferentemente de outras unidades de informação não pode ser uma entidade independente, afinal sua existência depende diretamente da escola. Sua função é ser agente educacional proporcionando informação, apoio curricular, bem como lazer e entretenimento por meio da leitura (PRADO, 1992). Ela 
"deve funcionar como um verdadeiro complemento da sala de aula, fornecendo todo o material bibliográfico necessário às atividades escolares" (FUNDAÇÃO BIBLIOTECA NACIONAL, 1995, p. 15), devendo ser entendida como "o coração de uma escola, e este coração deve ter participação ativa de toda a comunidade escolar" (BORBA, 2007).

Tavares (1970, p. 38), já havia observado que:

\begin{abstract}
devem os Governos Federal e Estaduais incluírem as Bibliotecas para crianças e jovens - públicas e Escolares - em seus programas de educação, como única maneira de possuírem as Escolas organismos auxiliares capazes de completarem sua tarefa, especialmente atendendo às novas características do ensino.
\end{abstract}

\title{
4.4 BIBLIOTECA INFANTIL
}

A biblioteca infantil é uma instituição que abriga um leque de atividades voltadas principalmente para crianças e adolescentes, podendo atender também a comunidade onde está inserida. Tem como propósito fazer com que seus usuários criem o hábito da leitura. É um espaço essencialmente lúdico, ou seja, é o lugar de brincar com os livros e com as letras, do faz de conta, do contar e do ouvir histórias (MELO; NEVES 2005). "É dedicada ao atendimento das crianças. Seu acervo é formado por livros de literatura infantil e infanto-juvenil, jogos e outros materiais recreativos" (FUNDAÇÃO BIBLIOTECA NACIONAL, 1995, p. 15).

A biblioteca pública infanto-juvenil é um centro cultural-recreativo de grande significação na vida da cidade, já que se propõe a ajudar à formação intelectual das crianças e jovens. É a biblioteca infanto-juvenil que vai fazer com que a criança goste de ler, que leva a criança a amar o livro, que lhe desperta a curiosidade e o interesse para com os livros, por meio de estórias que falam à imaginação infantil, criando o hábito de leitura que ficará por toda a vida, por mais diversos que sejam os seus interesses (TAVARES, 1970, p. 11).

A principal diferença entre a biblioteca escolar e a biblioteca infantil, para Tavares (1973) é que a biblioteca escolar tem como objetivo completar os estudos da criança, por meio da pesquisa e da informação, e seus usuários são os alunos da 
escola. Já a biblioteca infantil pública, procura formar o hábito de ler, despertar o amor aos livros e o gosto pela leitura, podendo atender as necessidades do leitor-estudante, apesar de não ser sua função. Em seu acervo os livros didáticos e de referência são em menor volume do que os livros de recreação e seus usuários são as crianças de uma comunidade.

As bibliotecas infanto-juvenis, sejam públicas ou escolares, são as mais relevantes para a formação do leitor e antecedem as outras bibliotecas (TAVARES, 1970). Para se educar é fundamental ter uma biblioteca, que contribua para a vitalidade e a riqueza das próprias escolas.

Toda biblioteca tem uma função pré-definida e a biblioteca infantil não é diferente, sua função é desenvolver o gosto e o hábito da leitura, incentivando e estimulando a aprendizagem, a criatividade e a comunicação da criança e do adolescente daquela instituição ou sociedade em que está inserida (MELO; NEVES, 2005). A literatura infantil tem a função de divertir, emocionar, educar, conscientizar, instruir, integrar e libertar (DÍDIMO, 1986, apud FERREIRA, 2007). As bibliotecas infantis estão exercendo funções comunitárias, pois suas atividades, tais como, educar, ensinar e recrear são de grande importância para a comunidade (TAVARES, 1970). A biblioteca tem uma função importante na formação das pessoas, afinal ela é fundamental para o desenvolvimento do processo educacional das crianças e adolescente da comunidade onde está envolvida. De acordo com a consideração de Melo e Neves (2005, p. 6):

O principal objetivo da biblioteca infantil é despertar o gosto pela leitura, o
espírito, a criatividade, o raciocínio lógico, proporcionar conhecimento, ampliar
conceitos e visão de mundo, desenvolver valores, assim como melhor
conhecer, promover e defender a Língua Portuguesa, estimulando a
consciência da identidade nacional.

Os usuários da biblioteca pública infantil são as crianças da comunidade (MELO; NEVES, 2005). Para Tavares (1970) existem três categorias de público que freqüentam uma biblioteca infanto-juvenil:

1. Crianças em idade pré-escolar;

2. Crianças em idade escolar;

3. Jovens adolescentes. 
As crianças em idade pré-escolar, ou seja, aquelas que ainda não sabem ler ou estão aprendendo, constituem um público especialíssimo da biblioteca, pois a criança não consegue permanecer em uma mesma atividade por muito tempo sem se cansar (TAVARES, 1970). De acordo com Porto (2000, p. 6) "mesmo ainda bebês, podem tomar conhecimento do livro com suas ilustrações coloridas sugerindo histórias e aventuras e, assim, aos poucos, prazerosamente, iniciarem o gosto pela leitura".

$\mathrm{Na}$ idade escolar as crianças, de 8 a 13 anos, constituem o público principal da biblioteca infanto-juvenil. É nessa fase que o bibliotecário forma o leitor, cria o hábito de ler, ao tornar a leitura um prazer (TAVARES, 1970). A literatura infantil "deve ser um instrumento de socialização, permitindo que a criança vivencie de maneira lúdica fatos que poderão vir a ajudá-la em experiências futuras." (FERREIRA, 2005). Este contato com o livro possibilita o desenvolvimento da linguagem, da cultural e do cognitivo nas crianças, pois estabelece novos padrões de raciocínio, abrindo novos espaços por meio dos quais elas possam se expressar, exercitando a criatividade (MELO; NEVES 2005).

O adolescente de uma biblioteca infanto-juvenil é um público, também, muito especial. As novas tecnologias, as mudanças e as atrações do mundo chamam sua atenção, de acordo com TAVARES, 1970, e confirmada por Ferreira (2005, s.p.):

\begin{abstract}
Muitos valores que são imprescindíveis na formação do ser humano estão sendo esquecidos ou substituídos por atitudes e ações que são tomados como modelo para a vida das pessoas. Em meio a tudo isso, percebemos a literatura, em especial a infantil, como uma forma de resgatar os valores e atuando junto às crianças para formar leitores críticos, participantes e transformadores dentro da comunidade onde vivem.
\end{abstract}

Quanto ao bibliotecário de uma biblioteca infantil, ele precisa saber despertar o gosto pela leitura, conhecer às preferências e os interesses das crianças (TAVARES, 1973). Para Suaiden (1995, p. 45) "os bibliotecários não tem que impor um tipo de leitura; deve, isso sim, ser um profissional disseminador de uma política de leitura." As atividades "são inúmeras e novas surgirão, nascidas das circunstâncias, do interesse dos leitores, da imaginação da Bibliotecária." (TAVARES, 1970, p. 26).

É importante que os educadores juntamente com os bibliotecários criem oportunidades para discussões, troca de idéias, assim proporcionando ocasiões nas quais a criança, além de desfrutar de recursos que não encontra em casa, possa ler, falar, ouvir, desenvolver seu vocabulário e espírito crítico (MELO; NEVES, 2005). 
Ferreira (2007, s.p.) tem "a certeza de que através da Literatura Infantil podemos iniciar uma redescoberta de valores e costumes e formar leitores críticos e participantes, sujeitos ativos dentro da sociedade onde estão inseridos."

A ilustração dos livros é um elemento interativo, pois com outra linguagem possibilita o diálogo do visual com o verbal, além de contribuir para o desenvolvimento intelectual das crianças, conforme afirma Carneiro (2007):

\begin{abstract}
Embora o livro infantil seja, muitas vezes, usado como tantos outros objetos culturais ou apenas lúdicos, feitos ou adaptados para diversão infantil [...] é uma produção artística vinculada a capacidade de interpretação do seu público alvo. Exige do autor a capacidade de sentir, de sonhar e de ver o mundo, através dos olhos da criança e compreendendo suas fantasias, ajudá-la na ampliação deste olhar em outras direções em busca da informação.
\end{abstract}

A biblioteca infantil é o centro recreativo da comunidade e deve procurar participar da vida dos seus leitores, de forma a atraí-los e ajudá-los. É uma das mais importantes instituições de educação e não pode faltar em nenhum sistema educacional que pretenda realmente servir à comunidade. É um dos mais importantes órgãos de cultura e educação de um povo, afinal as crianças e os jovens são o princípio e o futuro da nação (TAVARES, 1970).

O bibliotecário, como um auxiliar participante do processo do ensino deve promover meios para formar a convicção da relevância da leitura na comunidade e, especialmente, nas crianças e jovens (TAVARES, 1970). Para uma biblioteca ser conhecida na comunidade onde ela se encontra inserida é necessário que suas ações sejam desenvolvidas, visando seus usuários (BORBA, 2007). A biblioteca nada mais é que um centro cultural que deve servir a sociedade (MILANESI, 2003).

O serviço de informação à comunidade é o mais valioso instrumento que dispõe a biblioteca pública para atender eficientemente a seus usuários, e pode chegar a ser o meio mais eficaz de atração e conquista dos usuários, atingindo assim seu principal objetivo: servir à comunidade (SUAIDEN, 1995).

Uma forma de ampliar o conhecimento dos leitores é promover atividades que integrem a comunidade no processo de desenvolvimento cultural, por meio de diversos recursos como: comemorações, hora do conto, dramatizações, teatro de fantoches, cinema, jornal, palestras dentre outras (BORBA, 2007). Tem-se como exemplo de tal iniciativa a Biblioteca Infantil Monteiro Lobato, que no ano de 1970, cedia um dos salões 
para seus leitores comemorarem seus aniversários, aumentado os laços entre o leitor e a biblioteca (TAVARES, 1970).

Pode-se afirmar que "o critério fundamental da comunidade, portanto, está em que todas as relações sociais de alguém podem ser encontradas dentro da comunidade" (SUAIDEN, 1995, p. 13). A biblioteca infantil, cumprindo todos esses objetivos voltados a servir a comunidade, estará contribuindo para a formação de seus futuros cidadãos, que é o grande desafio para com as futuras gerações.

\title{
Brinquedoteca
}

Segundo definição de Ferreira (1995, p. 1051) lúdico é "relativo a jogos, brinquedos e divertimentos". Para a inclusão da atividade lúdica foi adicionada às bibliotecas infantis a brinquedoteca, a partir da valorização do brinquedo, tendo como objetivos básicos o empréstimo de brinquedos e a criação de espaços para realização de brincadeiras, como determinam Ramalho e Silva (2003/2004, p. 27).

\begin{abstract}
As atividades lúdicas possibilitam a incorporação de valores, desenvolvimento cultural, assimilação de novos conhecimentos, intercâmbio de idéias, desenvolvimento da sociabilidade e da criatividade bem como, o aprimoramento de várias habilidades destacando-se as motoras. Por intermédio do lúdico, a criança encontra o equilíbrio entre o real e o imaginário (RAMALHO, 2000, p. 53).
\end{abstract}

Segundo a caracterização de Kishimoto (1998 apud RAMALHO; SILVA, 2003/2004, p. 29) as brinquedotecas podem ser: escolares, comunitárias, hospitalares, universitárias e brinquedotecas em bibliotecas. Cada uma tem características próprias e atendem determinado usuário.

As brinquedotecas escolares possuem a função pedagógica e são organizadas em algum setor da escola, tendo como público alvo os alunos. As brinquedotecas comunitárias são aquelas mantidas por uma associação, prefeitura ou organização sem fins lucrativos, são móveis como bibliotecas circulantes servindo determinadas comunidades, ou estão estabelecidas em algum ônibus ou caminhão, levando brinquedos para as crianças usufruírem num determinado período.

As brinquedotecas hospitalares estão localizadas em algum departamento do hospital, auxiliam na recuperação e amenizam o trauma psicológico da hospitalização. 
As brinquedotecas universitárias têm como principal objetivo fornecer dados às pesquisas que ressaltem a importância dos jogos e brinquedos para a educação, realizados por profissionais da educação, psicólogos ou pesquisadores. E as brinquedotecas em bibliotecas são aquelas existentes em bibliotecas públicas ou privadas. No Brasil, as bibliotecas públicas geralmente recebem várias doações de brinquedos, utilizando-os para disponibilizar as crianças um espaço de lazer.

\subsection{RELAÇÃO DA CRIANÇA E DO ADOLESCENTE COM A BIBLIOTECA E A LEITURA}

A biblioteca infantil tem como objetivo primordial familiarizar as crianças com os diversos materiais que poderão enriquecer suas horas de lazer. Visa despertá-las para os livros e a leitura, desenvolvendo sua capacidade de expressar-se. De acordo com Sandroni e Machado (1991), é crucial incentivar a criança a ler, porém é necessário dar a liberdade de buscar o livro que a interessa e mostrá-la que as suas escolhas serão respeitadas.

A relação da criança com o livro é crucial para seu desenvolvimento pessoal, principalmente para crianças abaixo de seis anos, "a primeira infância se converte em uma idade importante para o processo de educação e amadurecimento de uma pessoa" (FRAGOSO, 1998, p. 45-46). É nesta fase que o contato com o livro ajuda no desenvolvimento do caráter, formando a base para a comunicação escrita e a criatividade.

A idade ideal de se estimular o habito de leitura é a infância, pois toda formação que se inicia na infância tende a se firmar na fase adulta, como afirma Carneiro (2008, p.50), o processo de leitura é complexo, pois envolve a junção de variáveis como "percepção, decodificação e processamento de informações; memória, predição, inferência, dedução, evocação, analogia, síntese, análise, avaliação e interpretação." A interpretação requer a capacidade de assimilar a mensagem, traduzir signos lingüísticos 
e interagir níveis de conhecimento para resultar significados, sendo necessário esforço e concentração (LIMA, 1982), qualidades que dificilmente se adquire sem prática.

Para a criança que está nos primeiros anos escolares

\begin{abstract}
a literatura pode ser importante aliada no desenvolvimento cognitivo, pois ativa a função simbólica, o imaginário, a linguagem, a compreensão do mundo através do faz-de-conta. Na literatura, a criança preenche significados e recria o mundo através do conhecimento e da emoção. (CARNEIRO, 2008, p. 51).
\end{abstract}

Uma das atividades literárias mais eficazes na construção do jovem leitor é a hora do conto, pois leva a diversos tipos de reações positivas nas crianças, se bem aplicadas. "O conto é recreação fundamental na formação educativo-cultural da criança. A linguagem escrita nasce da falada [...] toda a aprendizagem se apóia na conversação ou narração, e o conto é a sua expressão mais atraente" (CARVALHO, 1989, p. 55).

Para as crianças pequenas, que não são alfabetizadas, é aconselhável contar a história em voz alta, de preferência livros com história curta e que tenham várias ilustrações, assim a criança passa a se interessar por um mundo mágico, desejá-lo cada vez mais, até chegar o momento dela própria buscar histórias que lhe interessam. (SANTOS, 2006)

Para aqueles que estão em fase de alfabetização, o melhor livro é aquele com histórias curtas, com frases curtas, impressas em letras grandes. O conteúdo delas também é relevante na hora da escolha, é "importante sempre dar razão à fantasia e mostrar às crianças nesta idade contos e histórias que não dêem relevância excessiva à moral, assim como a lógica exacerbada." (SANTOS, 2006, p. 33).

\footnotetext{
O ato de ouvir histórias é o primeiro passo para ser um leitor, para descobrir que, através do livro, é possível encontrar idéias, satisfazer a curiosidade, encontrar soluções para um problema, descobrir que a realidade é cercada por conflitos, impasses, identificar-se com um personagem, superar as dificuldades, descobrir lugares novos. (BUENO; STEINDEL, 2006, p. 12).
}

A leitura, adicionada a atividade lúdica, auxilia a criança a compreender de forma mais efetiva a interação existente entre os indivíduos. Esses dois métodos são eficazes no sentido de aumentar o vocabulário infantil, já que despertam o conhecimento de novas palavras. O importante é estimular a leitura na criança como uma experiência 
valiosa e prazerosa, pois será uma fonte de satisfação, tanto para as crianças quanto para os adultos que as acompanharem nesta aventura. (RAMALHO, 2000)

Os adolescentes e a biblioteca, por sua vez, têm uma relação muito restrita. O adolescente não tem o hábito de freqüentar uma biblioteca a não ser pela necessidade de pesquisar sobre algum trabalho exigido pelo professor. Cada vez menos o adolescente é incentivado a adquirir o hábito pela leitura, isto porque seu referencial, no caso sua família (principalmente os pais) não tem este hábito e esta realidade se repete na biblioteca localizada na escola que não possui nenhuma política de incentivo, perdendo assim vários leitores em potencial.

O Brasil tem uma crise educacional chamada analfabetismo funcional, onde as pessoas lêem um texto, mas não entendem aquilo que lêem. A leitura vai além de leitura de signos, ela significa entendimento de conceitos. De acordo com HortaTavares (2008) o conceito de analfabetismo funcional foi criado pela Organização das Nações Unidas para a Educação, a Ciência e a Cultura/ UNESCO, em 1978, para referir-se a pessoas que, mesmo sabendo ler e escrever algo simples, não possuem as habilidades necessárias para viabilizar o seu desenvolvimento pessoal e profissional.

Esta falha começa justamente na escola e da falta de cuidado quanto à formação de leitores aptos a interpretar e pensar por si só, não só decorar fórmulas e conceitos.

Atualmente, o que dificulta mais este quadro é a forma como a sociedade supervaloriza os apetrechos tecnológicos, fazendo com que o adolescente se acostume com atividade que não requer muita concentração o que é o oposto da leitura.

Conforme Yunes $(1984$, p. 53)

O estímulo sistemático à leitura deveria ser meta prioritária em países em via de desenvolvimento. Constata-se no Brasil que o hábito de ler não representa uma tradição e, por isso, a motivação através de técnicas específicas deve ser encarada como um campo de estudo e pesquisa de novas modalidades que visem à aproximação do livro com o leitor. 


\title{
4.6 BIBLIOTERAPIA
}

A biblioterapia é a prática de usar livros sobre assuntos específicos ou temas para ajudar pessoas a lidar com os seus problemas, sejam de caráter social, emocional ou moral. Sua aplicação é feita em hospitais, prisões, asilos, orfanatos, ou seja, locais que lidam com o tratamento de problemas psicológicos em crianças, jovens, adultos, deficientes físicos, doentes crônicos e viciados.

Este método permite que a pessoa desenvolva um senso de identidade com novas perspectivas que conduzam à motivação no comportamento, para se adaptarem de maneira satisfatória às diferentes situações em suas vidas. (Hasse, 2004)

Ao ler ou ouvir uma história, o leitor se depara com um personagem com quem pode se identificar e participar de sua experiência, distanciando de seus próprios problemas. Ao mesmo tempo, encontra a possibilidade de encarar seus conflitos, sem medo, ansiedade ou autocrítica.

O ser humano através da leitura tem um envolvimento emocional com o texto, aplicando o que leu em sua própria vida. É essencial o papel da interpretação nas atividades biblioterapêuticas, pois é a oportunidade de unir a percepção objetiva e subjetiva. (OUAKNIN, 1996)

\begin{abstract}
A biblioterapia é primariamente uma filosofia existencial e uma filosofia do livro, que sublinha que o homem é um ser dotado de uma relação com o livro. Dessa forma, essa relação com o livro - a leitura - permite ao homem compreender o texto e se compreender. O leitor, ao interpretar, passa a fazer parte do texto interpretado. A interpretação é a junção da explicação objetiva do texto e da sua compreensão subjetiva. A interpretação descobre um outro mundo, o mundo do texto, com as variações imaginativas que a literatura opera sobre o real. A biblioterapia, portanto, propõe práticas de leitura que proporcionem a interpretação dos textos (OUAKNIN, 1996, p. 200).
\end{abstract}

Há diferenças entre uma simples leitura e a leitura terapêutica. A primeira é superficial com intuito de entreter, já a segunda faz parte de um processo terapêutico, que requer uma relação mais profunda com o texto. Este processo consiste numa atividade interativa baseada em interpretação de textos, destacando o diálogo. 0 diálogo é o fundamento da biblioterapia (OUAKNIN, 1996), ou seja, as etapas de entendimento de um texto incluem a interpretação em grupos que é o mais importante, 
pois dá oportunidade de troca de informações além de proporcionar a garantia de que o paciente ou cliente não está sozinho.

Outro ponto relevante nesta atividade é a escolha do texto que deve ser lido, a "seleção e prescrição de livros de acordo com as necessidades dos pacientes, condução da terapia baseada em comentários de leitura, e avaliação dos resultados" é necessária (RATTON, 1975, p. 199). Os resultados são variados, dependendo do método utilizado (leitura, atividades lúdicas, hora do conto, e outros). É nesta etapa de escolha do texto que entra o papel do bibliotecário que deve conhecer tanto os livros como os leitores, e a partir daí definir os efeitos de colocar os dois juntos.

\section{Através da Biblioterapia, pode-se constatar o nível emocional, social e cultural de cada paciente bem como o seu grau de depressão e ansiedade, sua própria reação a sugestão de leitura e alusão a outros livros ou histórias podem trazer informações importantes (FONTANELE et al., 1995, p. 16).}

A biblioterapia nasceu dos termos derivados das palavras latinas biblion (livros) e therapein (tratamento), segundo Caldin (2001). Seu significado se resume basicamente ao tratamento por intermédio da leitura. Foi constatado na literatura que os conceitos de biblioterapia se convergem, tanto nos profissionais da área de informação como os profissionais da área de educação e de psicologia, porém sendo uma atividade interdisciplinar, cada área encara a importância deste método de forma diferenciada.

As definições dos principais autores desta área estão apresentadas na Tabela 4: 
Tabela 4 - Conceitos e objetivos da biblioterapia ${ }^{1}$

\begin{tabular}{|c|c|c|}
\hline & Conceitos de Biblioterapia & Objetivos da Biblioterapia \\
\hline lice Bryan & $\begin{array}{l}\text { É a prescrição de materiais de } \\
\text { leitura que auxiliem a desenvolver } \\
\text { maturidade e nutram e mantenham } \\
\text { a saúde mental. }\end{array}$ & $\begin{array}{l}\text { Permitir ao leitor verificar que há mais de uma solução } \\
\text { para seu problema; auxiliar o leitor a verificar suas } \\
\text { emoções em paralelo às emoções dos outros; ajudar o } \\
\text { leitor a pensar na experiência vicária em termos } \\
\text { humanos e não materiais; proporcionar informações } \\
\text { necessárias para a solução dos problemas, e, encorajar } \\
\text { o leitor a encarar sua situação de forma realista de } \\
\text { forma a conduzir à ação. }\end{array}$ \\
\hline & \begin{tabular}{|l} 
É um método subsidiário da \\
psicoterapia; um auxílio no \\
tratamento que, através da leitura, \\
busca a aquisição de um \\
conhecimento melhor de si mesmo e \\
das reações dos outros, resultando \\
em um melhor ajustamento à vida.
\end{tabular} & $\begin{array}{l}\text { Fazer a introspecção para o crescimento emocional; } \\
\text { melhorar o entendimento das emoções; verbalizar e } \\
\text { exteriorizar os problemas; ver objetivamente os } \\
\text { problemas, afastar a sensação de isolamento; verificar } \\
\text { falhas alheias semelhantes às suas; aferir valores; } \\
\text { realizar movimentos criativos e estimular novos } \\
\text { interesses. }\end{array}$ \\
\hline $\begin{array}{l}\text { Kenneth } \\
\text { Appel }\end{array}$ & $\begin{array}{l}\text { É o uso de livros, artigos e panfletos } \\
\text { como coadjuvantes no tratamento } \\
\text { psiquiátrico. }\end{array}$ & $\begin{array}{l}\text { Adquirir informação sobre a psicologia e a fisiologia do } \\
\text { comportamento humano; capacitar o indivíduo a se } \\
\text { conhecer melhor; criar interesse em algo exterior ao } \\
\text { indivíduo; proporcionar a familiarização com a realidade } \\
\text { externa; provocar a liberação dos processos } \\
\text { inconscientes; oferecer a oportunidade de identificação } \\
\text { e compensação; clarificar as dificuldades individuais; } \\
\text { realizar as experiências do outro para obter a cura e } \\
\text { auxiliar o indivíduo a viver mais efetivamente. }\end{array}$ \\
\hline $\begin{array}{l}\text { Louise } \\
\text { Rosenblatt }\end{array}$ & $\begin{array}{l}\text { É uma ajuda para o ajustamento } \\
\text { social e pessoal; a literatura } \\
\text { imaginativa é útil para ajustar o } \\
\text { indivíduo tanto em relação aos seus } \\
\text { conflitos íntimos como em conflitos } \\
\text { com outros. Como o pensamento e } \\
\text { sentimento estão interligados, o } \\
\text { processo de pensamento reflexivo } \\
\text { estimulado pela leitura é um prelúdio } \\
\text { para a ação. }\end{array}$ & $\begin{array}{l}\text { Divide os objetivos em de cura e de prevenção. } \\
\text { Objetivos de cura: aumentar a sensibilidade social; } \\
\text { ajudar o indivíduo a se libertar dos medos e das } \\
\text { obsessões de culpa: proporcionar a sublimação por } \\
\text { meio da catarse, e, levar o ser humano a um } \\
\text { entendimento de suas reações emocionais. Objetivos } \\
\text { de prevenção: prevenir o crescimento de tendências } \\
\text { neuróticas e, conduzir a uma melhor administração dos } \\
\text { conflitos. }\end{array}$ \\
\hline Orsini & $\begin{array}{l}\text { É uma técnica que pode ser } \\
\text { utilizada para fins de diagnóstico, } \\
\text { tratamento e prevenção de } \\
\text { moléstias e de problemas pessoais. }\end{array}$ & $\begin{array}{l}\text { Classifica os objetivos como sendo de: nível intelectual, } \\
\text { nível social, nível emocional e nível comportamental. } \\
\text { Assim, a biblioterapia tem como objetivos: auxiliar o } \\
\text { auto-conhecimento pela reflexão, reforçar padrões } \\
\text { sociais desejáveis, proporcionar desenvolvimento } \\
\text { emocional pelas experiências vicárias e auxiliar na } \\
\text { mudança de comportamento. }\end{array}$ \\
\hline $\begin{array}{l}\text { Mattews } \\
\text { Lonsdale }\end{array}$ & $\begin{array}{l}\text { eonstitui-se em uma terapia de } \\
\text { leitura imaginativa, que compreende } \\
\text { a identificação com r uma } \\
\text { personagem, a projeção, a } \\
\text { introspecção e a catarse. }\end{array}$ & $\begin{array}{l}\text { Distinguiram três tipos a terapia de leitura: a de } \\
\text { crescimento, a factual e a imaginativa. Assim, os } \\
\text { objetivos são: divertir e educar, informar e preparar o } \\
\text { paciente para o tratamento hospitalar explorar os } \\
\text { sentimentos e tratar os problemas emocionais. }\end{array}$ \\
\hline Caldin & $\begin{array}{l}\text { É a leitura dirigida e discussão em } \\
\text { grupo, que favorece a interação } \\
\text { entre as pessoas, levando-as a } \\
\text { expressarem seus sentimentos: os } \\
\text { receios, as angústias e os anseios }\end{array}$ & $\begin{array}{l}\text { Proporcionar uma forma de as crianças comunicarem- } \\
\text { se, de perderem a timidez, de exporem seus problemas } \\
\text { emocionais e quiçá físicos; oferecer moderação das } \\
\text { emoções às crianças. }\end{array}$ \\
\hline
\end{tabular}
Fonte: ROSA, 2006, p.17

$1 \quad$ A Tabela 4 foi organizada pela autora Aparecida Luciene Resende Rosa, com base nos registros literários encontrados, com o objetivo de apresentar os conceitos de biblioterapia e, respectivos objetivos, de acordo com uma ordem cronológica a respeito do tema. 
Este método não é recente, tanto os egípcios como os gregos associavam a leitura como forma de tratamento espiritual e médico. Ferreira (2003) em seu estudo sobre biblioterapia relata que, no antigo Egito, as bibliotecas eram consideradas espaços de conhecimento e espiritualidade. Eram denominadas "casas de vida", segundo Momtet (1989 apud CRUZ, 1995, p. 13). O Faraó Rammsés II mandou colocar no frontispício de sua Biblioteca "Remédios para a alma" (ALVES, 1982). Na Grécia antiga, o método de curar por meio de livros fazia parte de sua cultura: na porta da Biblioteca de Tebas estava inscrito "lugar de cura da alma".

Ao final do século XVIII, os livros começaram a ser usados como tratamento para doentes mentais na França, Inglaterra e Itália. Benjamin Rush, em 1802, buscou usar o método de incentivo a leitura para doentes comuns em hospitais e John Minson Galt II que ficou conhecido pelo seu ensaio tratando da leitura, recreação e diversão no tratamento de pessoas insanas, em 1853, ambos médicos, foram os primeiros a recomendar a leitura como parte do tratamento de pacientes (ALVES, 1982).

Para a biblioteconomia começou um pouco mais tarde, "em 1904, quando a Biblioteca do Mc Lean Hospital, em Massachussets, iniciou um programa envolvendo os aspectos psiquiátricos da leitura." (RATTON, 1975, p. 199).

Este método biblioterapêutico passou a ter impacto na década de 1930 e sua intensificação na área médica deu-se na década seguinte, onde passou a ser tratada como ciência. Ferreira (2003) ressalta em seu estudo, que em 1938, Louise Rosenblatt indica pela primeira vez os benefícios do uso da biblioterapia: aumentando a compreensão social, permitindo ao sujeito colocar-se no lugar de outra pessoa e sentir suas necessidades, sofrimentos e aspirações; ajudar o paciente na assimilação de padrões culturais, por meio do reconhecimento das atitudes e expectativas do seu grupo; liberar o sujeito de uma atitude provinciana pela ampliação da consciência quanto à formação adquirida na família e na comunidade.

$\mathrm{Na}$ década de 1940, Caroline Shrodes torna-se a primeira doutora em biblioterapia, lançando as bases da biblioterapia atual. Em 1970, Sclabassi faz uma revisão de literatura classificando a pesquisa em quatro áreas profissionais: medicina geral, psiquiatria, educacional e corretiva, e categoriza a intervenção biblioterapêutica 
em quatro níveis: intelectual, social, emocional e comportamental (FERREIRA, 2003). $\mathrm{Na}$ década de 90, John Pardeck após publicações sobre a biblioterapia, ressalta que como qualquer outra terapia, há precauções e limitações, devendo ser vista como um adjunto a outras terapias.

A biblioterapia, em seu histórico, começou a ser utilizado em áreas médicas e educativas e só foi aplicada à área de biblioteconomia no século XX. Rosa (2006, p. 21) dentro deste contexto conclui que

devido ao fato de ter desenvolvido principalmente no ambiente dos hospitais e clínicas de saúde mental, a Biblioterapia foi aplicada quase de forma corretiva, e voltada para aspectos clínicos de cura e restabelecimento de pessoas com profundos distúrbios emocionais e de comportamento.

Só posteriormente ela foi aplicada em caráter preventivo nas crianças, adolescentes e jovens, em escolas, bibliotecas e centros comunitários.

\subsubsection{Tipos de Biblioterapia}

Os processos de aplicação da biblioterapia de acordo com Marcinko (1989) têm diferentes objetivos, podendo ser para desenvolvimento pessoal ou para processo clínico de cura. O trabalho da biblioterapia não se restringe a um tipo único de tratamento, sua aplicação é de caráter tanto preventivo quanto corretivo, pode ser então classificada em três tipos: institucional, clínica e desenvolvimental. Tanto Campos (2007), Pereira (1998) e Marcinko (1989) definem os diferentes tipos de Biblioterapia, que podem ser resumidas da seguinte maneira:

- A Biblioterapia Institucional é caracterizada pelo uso de textos de higiene mental, geralmente usado para pessoas hospitalizadas. Busca auxiliar um grupo ou uma instituição, prestar informação ao usuário e esclarecê-lo sobre um problema específico, ajudá-lo na tomada de decisão e reorientação de seu comportamento conforme o objetivo definido para o trabalho. É utilizada uma literatura didática. Essa terapia pode ser usada em grupo ou individual, aplicada por médicos ou bibliotecários. 
- A Biblioterapia Clínica busca trabalhar o comportamento das pessoas em seu desenvolvimento com questões emocionais. Sua atividade é feita em hospitais, clínicas e organizações de saúde mental. Seu objetivo é fazer com que os pacientes modifiquem suas atitudes e comportamento, encontrando soluções ou melhoras em sua atitude quanto ao seu problema. Neste caso é utilizada a literatura imaginativa e pode ser realizado por bibliotecários, psicoterapeutas e médicos.

- A Biblioterapia Desenvolvimental tem a finalidade de ajudar as pessoas em tarefas comuns além de auxiliar a lidar com problemas pessoais do cotidiano, para o desenvolvimento pessoal, tem o caráter preventivo e corretivo, utilizado muito em instituições educacionais. É empregada a literatura didática e imaginativa. Como não é ligada a medicina é realizado por bibliotecários, educadores, e outros.

As principais características de cada tipo são apresentadas na Tabela 5:

Tabela 5 - Características dos três tipos da biblioterapia

\begin{tabular}{|c|c|c|}
\hline & INSTITUCIONAL & DESENVOLVIMENTO \\
\hline FORMATO & $\begin{array}{l}\text { Individual ou grupoGrupo ativo, voluntário e } \\
\text { geralmente passivo }\end{array}$ & $\begin{array}{l}\text { Grupo ativo } \\
\text { Grupo voluntário }\end{array}$ \\
\hline CLIENTE & $\begin{array}{l}\text { Paciente médico ouPessoas com problemas } \\
\text { psiquiátrico, prisioneiroemocional } \\
\text { ou cliente em práticacomportamental } \\
\text { privada }\end{array}$ & $\begin{array}{l}\text { Pessoa normal geralmente em } \\
\text { situação de crise }\end{array}$ \\
\hline CONTRATANTE & Sociedade ou individual & Individual \\
\hline TERAPÊUTICA & $\begin{array}{l}\text { ouMédico, instrutor menta } \\
\text { ou bibliotecário }\end{array}$ & $\begin{array}{l}\text { Bibliotecário, professor } \\
\text { outros }\end{array}$ \\
\hline MATERIAL USADO & $\begin{array}{l}\text { Tradicionalmente } \\
\text { didático }\end{array}$ & $\begin{array}{l}\text { Literatura imaginativa e ou } \\
\text { didática }\end{array}$ \\
\hline TÉCNICA & \begin{tabular}{|l|l|} 
Discussão de material & $\begin{array}{l}\text { Discussão de materiais } \\
\text { com ênfase nas visões } \\
\text { reações do cliente }\end{array}$ \\
\end{tabular} & $\begin{array}{l}\text { Siscussão do material com } \\
\text { ê̂nfase nas visões e reações } \\
\text { do cliente }\end{array}$ \\
\hline LOCAL & \begin{tabular}{|l|l}
$\begin{array}{l}\text { Prática de instituição } \\
\text { pública ou privada }\end{array}$ & $\begin{array}{l}\text { Prática de instituição } \\
\text { privada } \\
\text { comunidade }\end{array}$ \\
\end{tabular} & Comunidade \\
\hline META & \begin{tabular}{|l|l|}
$\begin{array}{l}\text { Geralmente informativo Visão interna } \\
\text { com visão interna }\end{array}$ & $\begin{array}{l}\text { mudança } \\
\text { comportamento }\end{array}$ \\
\end{tabular} & $\begin{array}{l}\text { Comportamento } \\
\text { autorealização }\end{array}$ \\
\hline
\end{tabular}




\subsubsection{Componentes da biblioterapia}

O processo de biblioterapia é tão variado quanto as suas definições, porém sua aplicação segue uma lógica. O processo biblioterapêutico compõe da vários componentes de acordo com Caldin (2001): catarse, humor, identificação, introjeção, projeção e a introspecção.

O planejamento é um dos processos mais importantes ao trabalhar com a biblioterapia, pois permite o controle das atividades realizadas como também a sua avaliação. A primeira etapa é a seleção de um livro de acordo com a necessidade do leitor, buscando a resolução de seus conflitos, esta etapa é realizada pelo bibliotecário, pois "o bibliotecário deve conhecer o livro e os leitores, bem como a importância daqueles para estes." (GUMIEIRO et al., 2006, p. 41).

Hasse (2004) considera a biblioterapia praticada por terapeuta como uma ciência, já a praticada por bibliotecários como arte, sem controle científico necessário. Contanto Ouaknin (1996) diz que a diferença entre a biblioterapia e a psicoterapia é que a primeira é o contato de dois simples leitores, podendo cada um desempenhar o papel de terapeuta para o outro, enquanto que segundo é o encontro entre paciente e o terapeuta, onde o trabalho conjunto também pode ser realizado, pois "o bibliotecário deve, juntamente aos demais profissionais envolvidos com a biblioterapia, conduzir a informação de que necessitem e exercer o papel social de contribuição para a sociedade" (GUMIEIRO et al., 2006, p. 41).

Durante a leitura, o leitor capta as sensações do texto como, por exemplo, o humor que transforma o que seria objeto de dor em objeto de prazer, por isso é utilizado como um componente biblioterapêutico. O humor é uma forma de se proteger da dor. A leitura também proporciona uma sensação agradável que se denomina catarse, que estimula a formação de emoções (CALDIN, 2005). Quando uma pessoa busca uma leitura nem sempre é pela busca do conhecimento, muitas vezes é pelo desejo de ter um momento de entretenimento, sendo por isso que a leitura desempenha uma função catártica.

Uma das pioneiras no estudo e aplicação da biblioterapia, Shrodes (1949), considerou biblioterapia como um processo dinâmico entre leitor e texto literário, 
tendo o último a capacidade de provocar emoções no primeiro. Baseada na teoria da catarse aristotélica e na teoria freudiana da identificação, verificou, por meio de estudos experimentais, que a literatura ficcional pode seduzir, produzir mudanças comportamentais e induzir ao riso. Dessa forma, a literatura proporcionaria a reconciliação entre o prazer e a realidade, agindo sobre o leitor tanto de forma consciente quanto inconsciente (CALDIN, 2005, p. 15).

A leitura conduz o leitor a familiarizar com alguma situação ou personagem do texto, se sentindo no lugar do personagem, esta reação se chama identificação. As pessoas sempre buscam um modelo para seguir ou se identificar, o leitor encontra isso na leitura. Caldin (2005) afirma que quando alguém se identifica com um personagem, permite vivenciar situações que parece ser impossível na vida real, este processo é contínuo, tendo inicialmente a identificação com vários personagens e situações diferentes.

Depois, é feita a aplicação daquilo que foi lido em seu cotidiano, após o devido entendimento. Este processo é chamado de introjeção. Caldin (2005) ressalta que os componentes introjeção e projeção são ligados à identificação.

O diálogo, que tem um papel muito importante, é o trabalho de interpretação em grupo que busca o entendimento real do texto. O leitor precisa manifestar aquilo que foi assimilado, esta etapa é a projeção. Nesta etapa também há a reflexão do leitor e de sua situação, comparando a sua análise do texto, a Introspecção, ou seja, o modo do leitor aplicar em sua vida aquilo que foi lido e entendido.

[...] O leitor ou o ouvinte podem atribuir a si qualidades ou aspectos desejáveis da personagem da narrativa ficcional, absorvendo-os como se fossem seus, bem como atribuir à personagem suas dores, fraquezas e conflitos, para livrarse momentaneamente de sentimentos angustiantes e poder lidar com os mesmos. (CALDIN, 2005, p. 16).

\subsubsection{Métodos da Biblioterapia}

Podem-se destacar dois métodos relevantes de biblioterapia no trabalho com crianças: a leitura e as atividades lúdicas. 
Segundo Caldin (2001, p. 4), "o método biblioterapêutico consiste em uma dinamização e ativação existencial por meio da dinamização e ativação da linguagem". A dinâmica da leitura possibilita interpretações e por meio de determinados métodos esta leitura traz uma identificação para resoluções de problemas. Bamberger (1995, p. 20) que estuda a leitura envolvendo a pedagogia ressalta que

\begin{abstract}
a pesquisa sobre leitura, um dos ramos mais jovens da ciência, projetou nova luz sobre o seu significado, não só em relação às necessidades da sociedade, mas também às do indivíduo. $O$ direito de ler significa igualmente o de desenvolver as potencialidades intelectuais e espirituais, o de aprender e progredir. [...] para os jovens leitores, os bons livros correspondem às suas necessidades internas de modelos e ideais, de amor, segurança e convicção. Ajudam a dominar os problemas éticos, morais e sociopolíticos da vida, proporcionando-lhes casos exemplares, auxiliando na formação de perguntas e respostas correspondentes.
\end{abstract}

Dentro da leitura, Bamberger (1995, p. 14) classifica-os pelos leitores. "Os tipos de leitores relacionam-se intimamente com as motivações para ler, como se reflete nas várias espécies de leitura escolhidas de acordo com a motivação ou a intenção." A leitura, então, pode ser: informativa, escapista, literária e cognitiva.

- Leitura informativa: a principal motivação é a necessidade de orientação na vida e no mundo.

- Leitura escapista: remota a necessidade de satisfazer desejos. Esse tipo de leitura predomina em crianças. A pessoa deseja escapar à realidade, viver num mundo sem responsabilidades nem limites.

- Leitura literária: constitui, também, uma busca além da realidade. Procura o significado interno, o reconhecimento do simbólico nos acontecimentos cotidianos.

- Leitura cognitiva: tem a mesma motivação que a filosofia: o anseio do conhecimento e da compreensão de si mesmo, dos outros e do mundo.

A leitura vai "além do texto (seja ele qual for) e começa antes do contato com ele. O leitor assume um papel atuante, deixa de ser mero decodificador ou receptor passivo." (MARTINS, 1994, p. 8). A sensação de viver situações inesperadas torna o ato da leitura cada vez mais atrativo. A criança tende a ter uma maior disponibilidade a ler do que o adulto, pois para ela tudo é novo e desconhecido (MARTINS, 1994). 
A leitura, de acordo com Caldin (2001), por si só não proporciona o necessário para se tornar um método biblioterapêutico. O trabalho por meio da leitura pode ser realizado tanto individualmente como também em grupo. Um método conhecido é a hora do conto que é realizado com crianças, onde é contada uma história e a partir desta leitura são feitas atividades que auxiliem em sua compreensão.

A ludoterapia (terapia por intermédio de atividades lúdicas) "é uma forma de intervenção psicológica com crianças que se baseia na brincadeira como meio de autoexpressão" (NASCIMENTO, 2004, p. 3). Esta atividade auxilia no desenvolvimento físico, mental e social. Os objetos lúdicos, dentro da biblioterapia, têm o papel de coadjuvante. "A ludoterapia é mais eficaz com crianças entre três e seis anos de idade. No entanto, com o uso de jogos e histórias, pode-se atender crianças de sete a doze anos, e até jovens adolescentes" (CARLSON; ARTHUR, 1999, p. 215).

A criança utiliza a brincadeira como forma de expressão da linguagem, em vez de falar ela expressa fisicamente. A ludoterapia permite a criança ser ela mesma. Durante a sessão ela é a pessoa mais importante, ninguém lhe diz o que fazer, e desta forma ela sente liberdade. É importante esta sensação, pois ela se sente segura neste ambiente.

\subsection{A APLICAÇÃO DA BIBLIOTERAPIA DESENVOLVIMENTAL EM CRIANÇAS E ADOLESCENTES QUE RESIDEM EM ORFANATOS}

A Biblioterapia é indicada àquelas pessoas que estão lidando com algum problema, por isso é indicada as crianças e adolescentes que estão afastadas de seu ambiente familiar, estando em creches, hospitais e, como neste trabalho, em orfanatos.

Orfanatos são instituições mantidas pelo governo ou por organizações não governamentais (ONGs), que agregam e abrigam crianças e adolescentes abandonados pelos pais. Os conflitos interiores que a criança ou adolescente que residem em um orfanato podem sentir são profundos, pois a família é a base da formação do indivíduo, desde o seu caráter e valores. Esta valorização da família é 
passada às crianças e aos adolescentes seja pelos amigos, como pela própria escola, criando um sentimento de abandono e de deslocamento social.

Os orfanatos foram criados para abrigar crianças e adolescentes advindos dessa ruptura familiar. É um espaço onde se tenta criar um ambiente familiar, no entanto, ainda necessita agregar a ele maior participação do sistema informacional com o processo de cidadania. Dentro desta concepção a proposta vem a complementar programas educacionais desenvolvidas pelo governo e por algumas ONGs. (CARVALHO, 2000)

O trabalho biblioterapêutico ideal neste caso deve ser o de desenvolvimento pessoal, o da Biblioterapia Desenvolvimental, pois visa a mudança de comportamento por meio do auto-conhecimento, utilizando qualidades racionais e emocionais dos indivíduos. Ela "é descrita como apoio literário personalizado para possibilitar um desenvolvimento normal e progressivo da pessoa" (FERREIRA, 2003, p.39).

A leitura ideal para este tratamento é a literatura de ficção e a literatura didática. Para Ferreira (2003) a leitura proporciona a assimilação de um novo conhecimento como também uma nova percepção da realidade externa e com isso a pessoa se modifica, seja nos seus valores, atitudes e comportamento.

O papel do bibliotecário neste processo é de suma importância se este profissional estiver apto a realizar as atividades propostas. É indicado um treinamento especial para a aplicação da Biblioterapia e a possibilidade de trabalhar com outros profissionais de áreas como educação e psicologia.

Ferreira (2003) aborda algumas diretrizes básicas a serem seguidas pelo bibliotecário, sendo elas:

a) escolher um local adequado para a realização das reuniões do grupo;

b) ter um treinamento adequado e estar capacitado para conduzir as discussões do grupo;

c) formar grupos homogêneos para leitura e discussão de temas previamente escolhidos;

d) preparar listas de material bibliográfico adequadas às necessidades de cada grupo, e escolher outros materiais (filmes, músicas), de acordo com a idade e necessidades, no nível cultural e social dos participantes; 
e) mesmo que não haja aplicação de terapia ou psicoterapia, como em alguns casos de biblioterapia para crianças, é necessário estabelecer uma situação de ajuda entre o bibliotecário e o usuário, e a partir daí elaborar um programa estruturado;

f) o bibliotecário ou biblioterapêuta deve usar de preferência material com os quais estejam familiarizados;

g) selecionar materiais que contenham situações familiares aos participantes do grupo, mas que não precisam necessariamente conter situações idênticas às vividas pelas pessoas envolvidas no processo;

h) selecionar materiais que traduzam de forma precisa os sentimentos e os pensamentos das pessoas envolvidas sobre os assuntos e temas abordados, com exceção de materiais que contenham uma conotação negativa do problema, como poesias sobre suicídios, por exemplo;

i) selecionar materiais que estejam de acordo com a idade cronológica e emocional da pessoa, sua capacidade individual de leitura e suas preferências culturais e individuais e

j) selecionar material impresso e não impresso na mesma medida.

Este tipo de biblioterapia é aplicado de preferência em grupos homogêneos, principalmente da mesma faixa etária, por isso a abordagem com as crianças é diferente daquela feita aos adolescentes, pois cada um tem uma forma de lidar com sua angustia e seus problemas, como também têm interesses distintos. O desenvolvimento pessoal da criança está voltado para a detenção de autoconfiança enquanto que para o adolescente é a necessidade de desenvolver um senso de identidade. (FERREIRA, 2003).

Bueno e Caldin (2002) ressaltam que é importante para uma criança, que sente fragilidade por causa da ausência de seus pais, um ambiente para aliviar suas tensões, com sessões de leitura e atividades auxiliares que proporcionam momentos onde a criança acaba viajando num mundo de fantasia e aventura.

Quando se trabalha a biblioterapia com crianças deve-se ter o cuidado na abordagem. Para Bueno e Caldin (2002) a criança deve ser preparada para assimilar este tipo de atividade. Nem todas as histórias são adequadas para se trabalhar com crianças, principalmente àquelas que estão hospitalizadas ou que passaram algum 
trauma como abuso por parte dos pais. Não são indicadas as histórias muito complexas ou que tenha atividades que a criança não possa realizar.

Nas histórias infantis são identificadas várias oposições como: conflitos entre o bem e o mal, abordagem sobre a coragem e a covardia, o medo e a segurança, elas são o que enlaçam a história. É muito importante que o bibliotecário ao selecionar um livro para ser trabalhado entenda que nem todas as histórias infantis são adequadas, por exemplo, os contos de fada podem ou não ser benéficos para as crianças. Segundo Cashdan (2000), deve-se tomar muito cuidado com alguns contos que estimulem à vaidade, a gula, a inveja, a mentira, a luxúria, a avareza, a preguiça. Nestes casos, deve-se ajudar a criança a lidar com estas questões por meio de indagações de como estas situações já influenciaram sua vida e de que modo foram superadas.

\footnotetext{
É interessante ressaltar que a criança se sente fragilizada, principalmente quando seus familiares não podem permanecer ao seu lado. O desconforto presente nestes casos pode ser aliviado com as sessões de leitura e atividades auxiliares. A criança, estimulada pela novidade, acabará viajando num mundo de fantasias e aventuras, cuja ferramenta-chave é o livro (BUENO; CALDIN, 2002, p. 159).
}

A biblioterapia, aplicada com crianças, pode alcançar vários objetivos como despertar o gosto pela leitura, estimular a socialização e permitir momentos de descontração e prazer. A leitura, associada as atividades lúdicas, é um instrumento eficaz na conquista da melhoria da qualidade de vida dessas crianças, e é um dos objetivos de se aplicar esta técnica terapêutica em crianças.

Os adolescentes que moram em orfanato tiveram, em geral, experiências de violência e abandono, que os levaram a ter dificuldades de buscar contato real consigo e com o mundo. Santos (2002) defende que o adolescente deve encontrar diferentes maneiras de lidar com as situações que o aflige. É importante também compartilhar as experiências, promovendo assim novas formas de relação consigo e com os outros.

A leitura e as atividades lúdicas são essenciais para proporcionar a estes adolescentes a melhoria da qualidade de vida. Dentro das atividades lúdicas podem-se adaptar também atividades de arte em vez de brincadeiras muitas vezes infantis, visto que, de acordo com Santos (2002) estas atividades possibilitam a ampliação de experiências de contato para descobrirem seu jeito próprio de lidar com as situações e com os sentimentos. 


\title{
4.8 A BIBLIOTECA ESCOLAR NO PROCESSO DE ENSINO - APRENDIZAGEM
}

O processo ensino-aprendizagem está intimamente ligado a biblioteca escolar e suas atividades, visto que acompanha o aluno em seu desenvolvimento intelectual. $A$ biblioteca escolar é um instrumento de socialização.

Ao se falar do processo ensino-aprendizagem, o primeiro ponto a ser entendido é da instituição de ensino, pois é a que determina qual deverá ser o processo de ensinoaprendizagem utilizado. Reimer (1979, p. 51) define uma instituição de ensino como "uma instituição que exige a freqüência de grupos etários específicos em classes, sob a supervisão de professores, para o estudo de um determinado currículo".

Sales (2004, p. 45) afirma que:

\begin{abstract}
Quando o termo educação é mencionado, geralmente, remete-se a um elemento capaz de garantir, especialmente às crianças e aos jovens, desenvolvimento cognitivo e discernimento suficientes para sua integração no convívio social. Assim, espera-se que a Escola, que é a institucionalização, a objetivação deste elemento, dê a estes sujeitos as condições necessárias para uma participação efetiva na vida social, através da construção de conhecimentos, dos quais deverão usufruir durante toda sua existência.
\end{abstract}

A escola de acordo com Sales (2004) deve dispor de uma estrutura que permita ao aluno ampliação de seus conhecimentos em suas interações sociais. É fundamental ter um local com materiais de assuntos trabalhados e pessoal pedagógico especializado que esteja disponível aos alunos. A educação pode ser considerada um sistema. O conceito de sistema que se aplica a instituição educativa. Bordenave e Pereira (2000) consideram também o processo mais restrito do ensino-aprendizagem como as estratégias didáticas.

Um aspecto que torna a estratégia de ensino um sistema é o processo constante que permite o sistema mudar seus métodos de acordo com sua necessidade.

Ao definir os objetivos estabelecidos é necessário prever a estratégia que proporciona ao aluno encontrar respostas. Esta estratégia é definida pelas experiências de aprendizagem e atividades de processo de ensino-aprendizagem, conforme Figura 6 : 


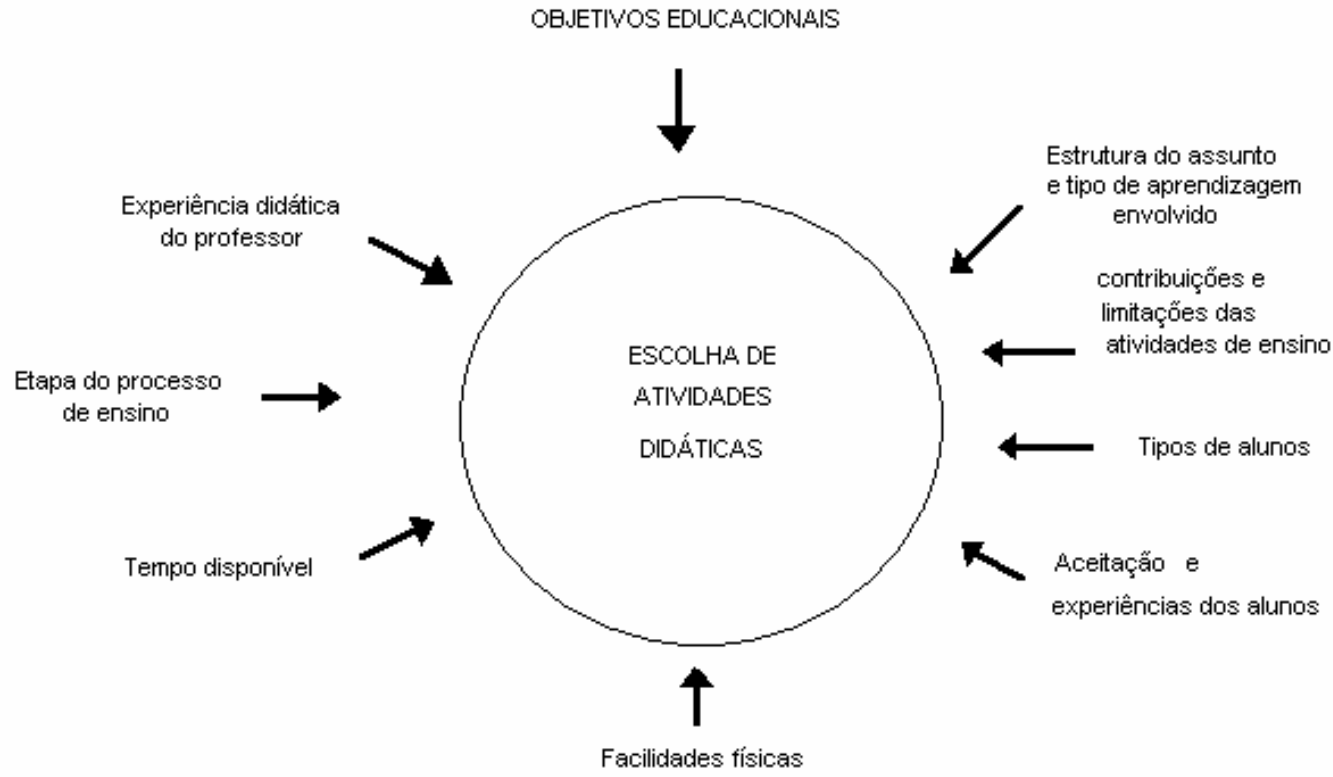

Fonte: Bordenave; Pereira, 2000, p. 123

Figura 6 - Fatores que afetam a escolha de atividades didáticas

As atividades deste processo de ensino-aprendizagem são instrumentos que o professor utiliza para abordar certos conteúdos para que os alunos obtenham um crescimento por meio de experiências (BORDENAVE; PEREIRA, 2000), conforme Figura 7:

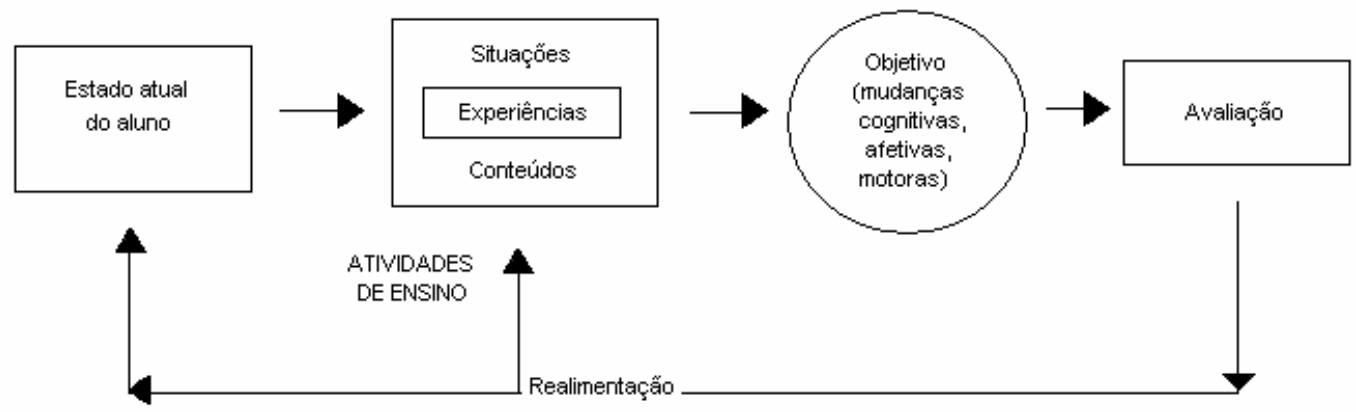

Fonte: Bordenave; Pereira, 2000, p. 124.

Figura 7 - As atividades de ensino-aprendizagem devem variar segundo os objetivos. 
Os Parâmetros Curriculares Nacionais (PCN) são como referencial que a Secretaria de Educação Fundamental do MEC coloca à disposição dos educadores brasileiros para orientá-los quanto ao conteúdo curricular. No PCN, a biblioteca tem um papel essencial na aprendizagem, pois além de estar ligada ao universo da leitura também é um espaço da busca de informação (CAMPELLO et al., 2001).

A biblioteca escolar tem como função "servir de base aos objetivos da escola" (TAVARES, 1973, p. 14). Ela funciona como um centro, que junto às atividades da própria escola, deve aprimorar o rendimento do aluno, pois contêm o fundamento de tudo o que é aprendido: "um acervo bem selecionado e equilibrado, colocando à disposição de professores e alunos, enriqueceria e vivificaria o processo de ensinoaprendizagem" (QUINHÕES, 1999, p. 178). Da mesma forma que a escola deve ser um sistema dinâmico, a biblioteca deve participar do processo de desenvolvimento curricular.

Os objetivos da biblioteca escolar devem ser os mesmos da escola. Quinhões (1999, p. 179) define a biblioteca escolar "como responsável pela difusão de informações atuais e indispensáveis ao processo ensino-aprendizagem, colabora para uma democrática educação integral, alcançada através de atividades que levem o educando a formação do senso de responsabilidade, cidadania e capacidade de autorealização".

Kuhlthau (1999) ao definir o papel da biblioteca escolar no processo de aprendizagem, afirma que as Bibliotecas da Sociedade da Informação estão se adaptando para que o aprendizado seja baseado no questionamento, onde o estudante esteja envolvido em todo o processo de construção de significados. Este processo de busca de informação ocorre em seis estágios: iniciação, seleção, exploração, formulação, coleta e apresentação, e um estágio adicional de avaliação.

A iniciação é o primeiro estágio deste processo, a partir de um problema em que o aluno questiona sobre aquilo que ele sabe sobre o assunto, bem como para novos questionamentos, e volta sua mente para as oportunidades de aprendizagem. $O$ aluno tem uma necessidade e um objetivo. 
Todo processo de ensino, segundo Bordenave e Pereira (2000) deveria iniciar-se entendendo o "estado atual" do aluno, ou seja, qual o nível de conhecimento que ele tem sobre o assunto.

A seleção é o estágio em que o aluno determina o assunto geral de sua pesquisa. A exploração por sua vez é o momento do aluno ler e refletir para que possa entender o assunto, é uma etapa de orientação muito delicada, visto que, envolve o ânimo e a iniciativa do aluno.

Nestes dois estágios, a biblioteca exerce sua função de disseminadora da informação. O papel do bibliotecário da referência pode direcionar para o assunto relevante.

A formulação é o mais importante, pois é nesta fase que o aluno desenvolve uma perspectiva focalizada, e precisa de orientação, pois é neste estágio que o trabalho toma forma.

A coleta é o momento de reunir informação, em que as estratégias usadas nas pesquisas da biblioteca são utilizadas. A apresentação é a etapa final em que o aluno completa o seu trabalho e apresenta às outras pessoas aquilo que ele entendeu. E por fim feito o trabalho o estudante pode rever aquilo que foi feito e fazer sua própria avaliação.

A biblioteca é um instrumento de auxílio no processo ensino-aprendizagem, que atende professores e alunos, otimizando sua relação com o ensino e aprofundando seu conhecimento. 


\section{ESTUDO DE CASO: Biblioteca Infanto-Juvenil do Orfanato Lar Rita de Cássia}

Este trabalho tem como objetivo propiciar informações aos internos do Orfanato Lar Rita de Cássia, para isso será proposto uma biblioteca que utilize atividades biblioterapêuticas no Orfanato Lar Rita de Cássia e para tal, é necessário fazer um levantamento sobre a situação atual dos sistemas envolvidos com esta biblioteca.

\subsection{Valparaiso de Goiás}

Valparaíso de Goiás surgiu em 19 de abril de 1979, quando o prefeito de Luziânia, Walter José Rodrigues, inaugurou o pequeno Núcleo Habitacional Valparaízo I, em função da construção de Brasília. Em solenidade oficial, empossou o primeiro administrador regional da localidade, Clóvis José Rizzo Esselin de Oliveira Almeida. O mais novo Núcleo Habitacional de Luziânia contava com apenas 864 casas, uma escola estadual e o prédio da administração regional. O Núcleo Residencial, construído pela Encol, começou com muitos problemas: não havia comércio, a falta de água era freqüente e só havia transporte coletivo na BR-040.

No dia 2 de maio de 1980, através do Decreto-Lei no 972, ficou instituída e oficializada a data de 19 de abril para comemorar o aniversário da fundação do Núcleo Habitacional Valparaízo. Nesta época, Valparaíso já contava com um posto telefônico, uma agência de Correios e Telégrafos, um escritório de contabilidade e onze lojas comerciais. A atual cidade de Valparaíso de Goiás está localizada na região do entorno do Distrito Federal, a cerca de 30 km de Brasília e 120 km da capital de Goiás, Goiânia. Sua população estimada é de aproximadamente 120 mil habitantes. Valparaíso é servida por diversas estradas, que são: BR-040, BR-060, BR-020 BR-251 e DF-290. A sua área é de aproximadamente 60.111 km², e os municípios limítrofes são: Cidade Ocidental, Luziânia, Novo Gama e Distrito Federal. 
Elevado à categoria de município com a denominação de Valparaíso de Goiás, pela lei estadual $n^{\circ}$ 12667, de 18 de julho de 1995, desmembrado do município de Luziânia. Constituído do distrito sede em 1 de janeiro de 1997. Na Figura 11 observa-se a localização de Valparaíso de Goiás, como entorno de Brasília.

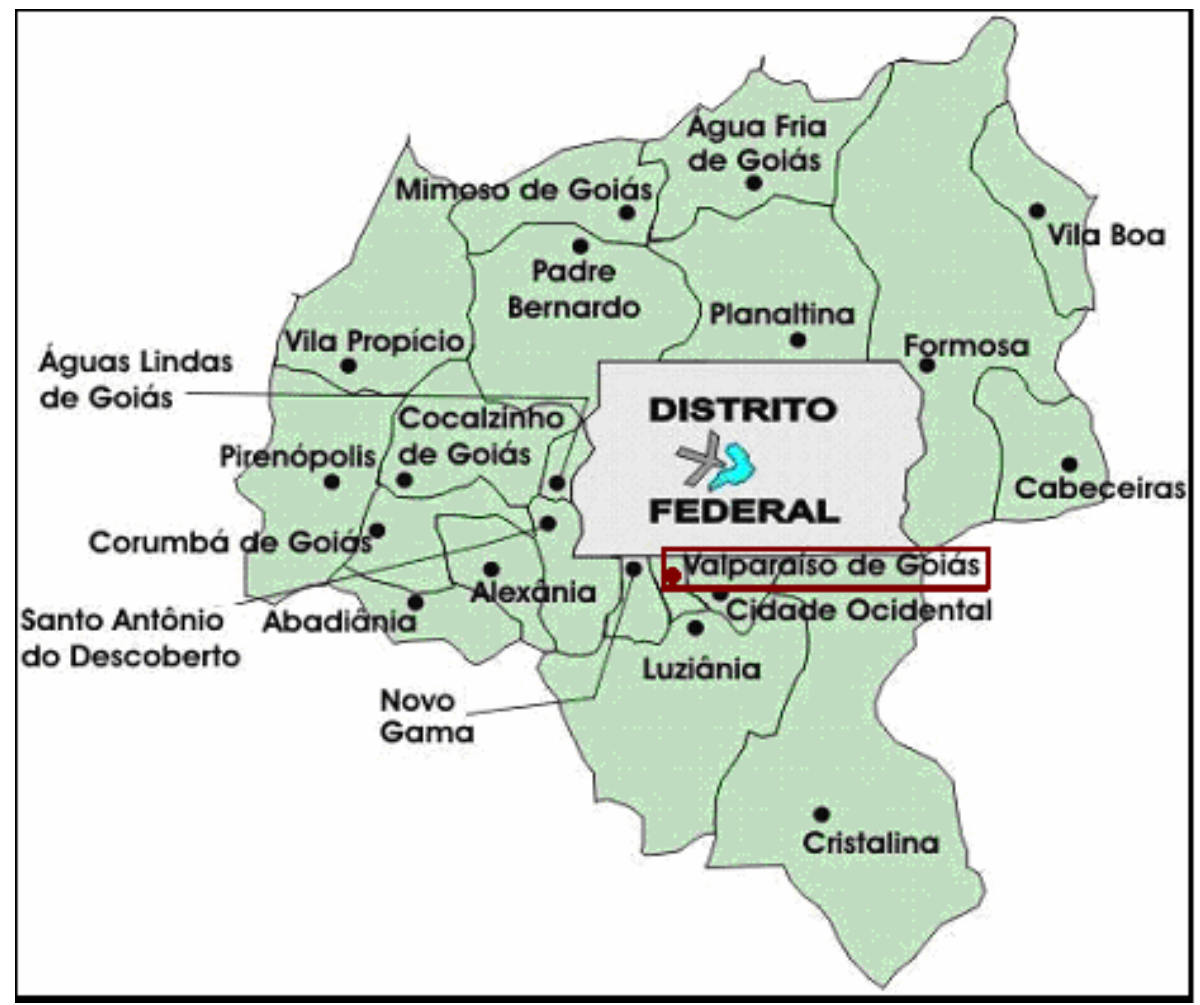

Fonte: SEPLAN, 2008.

Figura 8 - Mapa do Entorno de Brasília

A seguir serão apresentados os dados socioeconômicos. Do município de Valparaíso de Goiás.

\section{Crescimento Populacional}

Os censos servem para levantamento de dados fundamentais à formulação de políticas públicas e tomada de decisões acerca de investimentos privados e governamentais. Em Valparaíso de Goiás, os dados coletados, por meio de contagem, 
demonstram que em oito anos (2000-2008) a população cresceu em 26.022 habitantes, com um crescimento médio anual de aproximadamente 2.891 hab/ano.

As estimativas de crescimento da população são realizadas pelo método geométrico. Em termos técnicos, para se obter a taxa de crescimento, subtrai-se 1 da raiz enésima do quociente entre a população final e a população no começo do período considerado, multiplicando-se o resultado por 100, sendo "n" igual ao número de anos no período. O cálculo é complexo, em geral, restrito a demógrafos.

$$
I=\left(P_{(t+n)} / P_{(t)}\right)^{1 / n}-1
$$

Sendo, $P(t)$ a população no início do período (ano t); $P(t+n)$ a população no ano, $\mathrm{t}+\mathrm{n}$ e $\mathrm{n}$ o intervalo de tempo entre dois períodos e I a taxa de crescimento considerada, menos um.

Resumidamente, a Taxa Geométrica de Crescimento tem o valor que se refere à média anual obtida para um período de anos entre dois censos demográficos, indicando a intensidade de crescimento anual da população residente. A taxa é influenciada pela dinâmica da natalidade, da mortalidade e das migrações.

Tabela 6 - Taxa Geométrica de Crescimento de Valparaíso de Goiás

\begin{tabular}{|lllll|}
\hline Taxa Geométrica de Crescimento & & \\
\hline Ano & $\mathbf{2 0 0 0 / 2 0 0 5}$ & $\mathbf{2 0 0 0 / 2 0 0 6}$ & $\mathbf{2 0 0 0 / 2 0 0 7}$ & $\mathbf{2 0 0 0 / 2 0 0 8}$ \\
\hline Taxa & $4,73 \%$ & $4,56 \%$ & $2,72 \%$ & $3,08 \%$ \\
\hline Fonte: SEPIN, 2008. & & & \\
\hline
\end{tabular}

Estatisticamente, a Taxa Geométrica de Crescimento de Valparaíso de Goiás diminui no período de 2006 a 2007, crescendo novamente de 2007 a 2008 . Este quadro é demonstrado tanto na Tabela 6, quanto na Figura 9 com uma curva de crescimento demográfico, no período de 2000 a 2008, como também na Figura 10 que representa, com valores absolutos, a população de Valparaíso de Goiás neste mesmo período. 


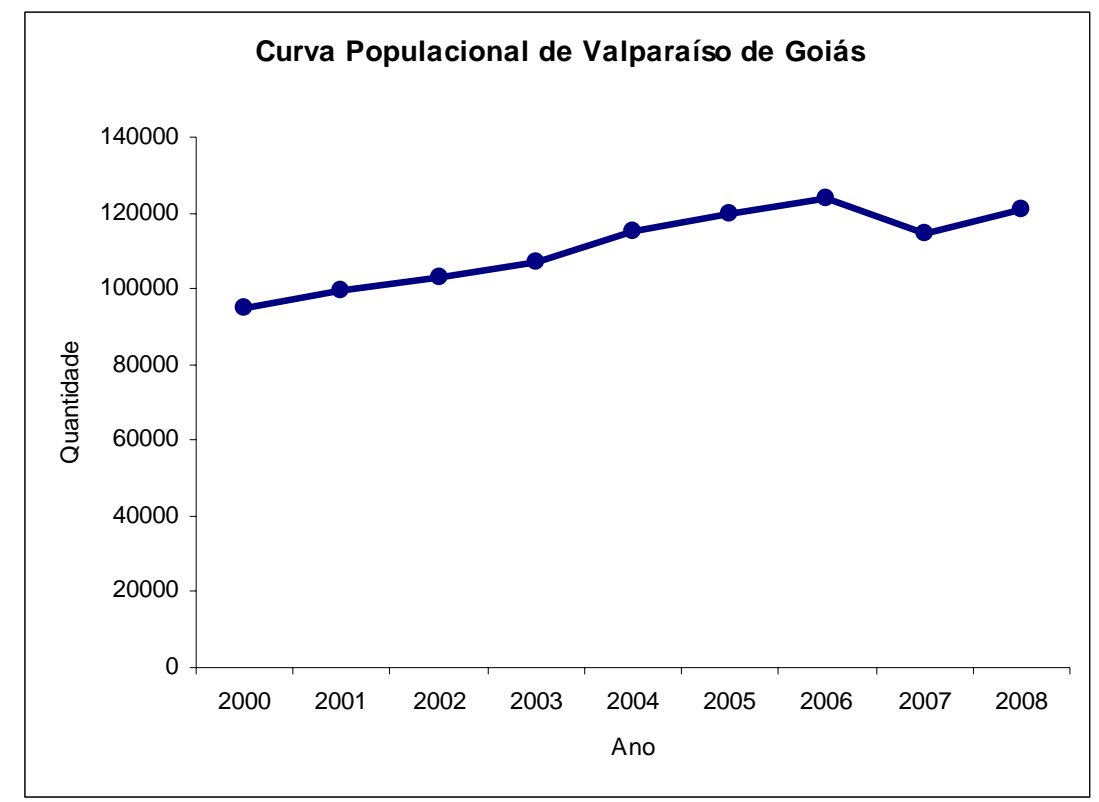

Fonte: SEPIN, 2008.

Figura 9 - Curva Populacional de Valparaíso de Goiás

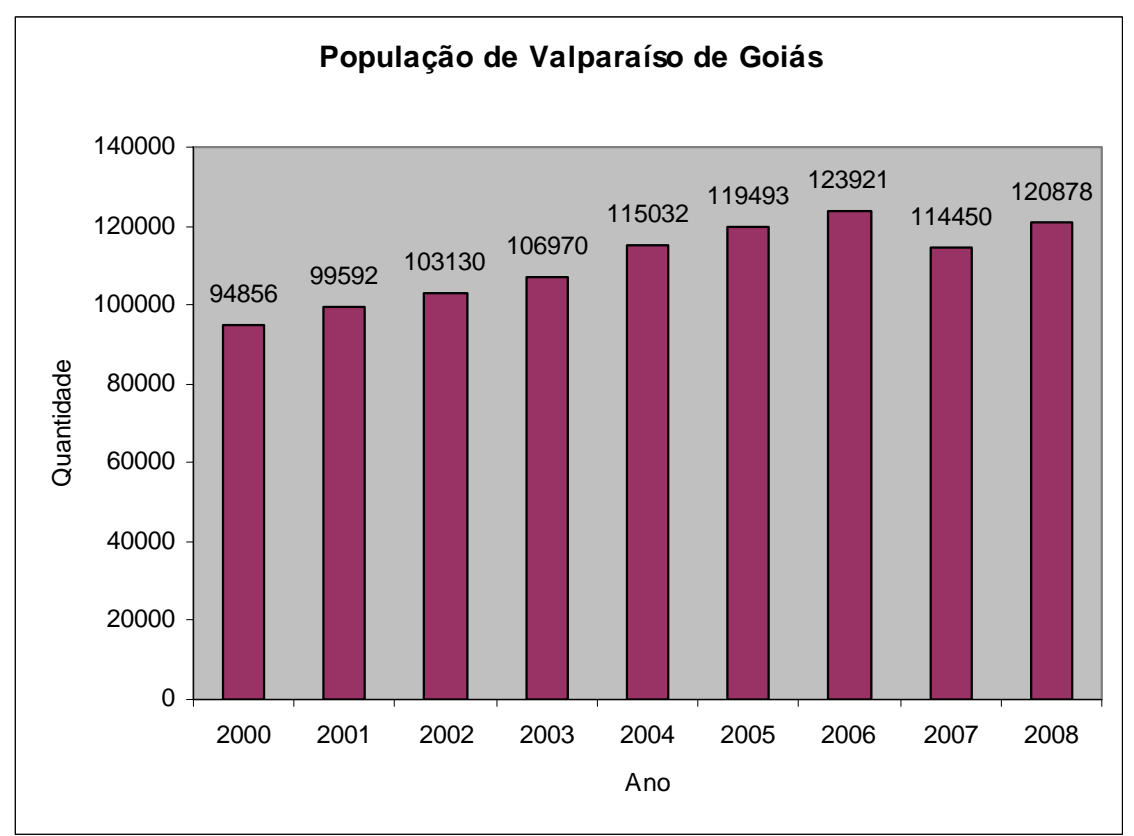

Fonte: SEPIN, 2008.

Figura 10 - População de Valparaíso de Goiás 


\section{Educação e Saúde}

$\mathrm{Na}$ área educacional, a cidade contava, inicialmente, com uma escola estadual que atendia aos alunos do primeiro grau e duas escolas particulares, que já se encontram extintas. No aspecto religioso, o bairro contava com uma igreja católica, duas igrejas batistas, uma Assembléia de Deus e uma Loja Maçônica. Em Valparaíso de Goiás há 2 hospitais com 37 leitos, sua taxa de mortalidade infantil (por 1000 nascidos vivos), em 2000 é de 18,98\%.

Os dados da Tabela 7 não demonstram muitas variações quanto ao número de escolas em atividade, a maior diferença foi o aumento de seis escolas em um ano, de 2000 a 2001, enquanto isso o número de salas de aula segue em um crescimento contínuo até 2004, quando inicia uma diminuição constante.

Tabela 7 - Educação

\begin{tabular}{|l|l|l|l|l|}
\hline \multicolumn{2}{|l}{ Educação } & Salas de Aula & Docentes & Total de Alunos \\
\hline Ano & Escolas em Atividade & 550 & 1115 & 30381 \\
\hline 2000 & 52 & 608 & 1238 & 32907 \\
\hline 2001 & 58 & 676 & 1340 & 35482 \\
\hline 2002 & 59 & 695 & 1359 & 36308 \\
\hline 2003 & 62 & 737 & 1360 & 36471 \\
\hline 2004 & 61 & 703 & 1294 & 34937 \\
\hline 2005 & 59 & 702 & 1228 & 33961 \\
\hline 2006 & 61 & & & \\
\hline
\end{tabular}

A relação do número de docentes com o número de alunos é representada pela Figura 11, o mesmo processo de crescimento do número de sala de aula, acontece com o corpo docente que chega a seu ápice em 2004, enquanto que o número de alunos chega a seu ápice antes disso, em 2003. 


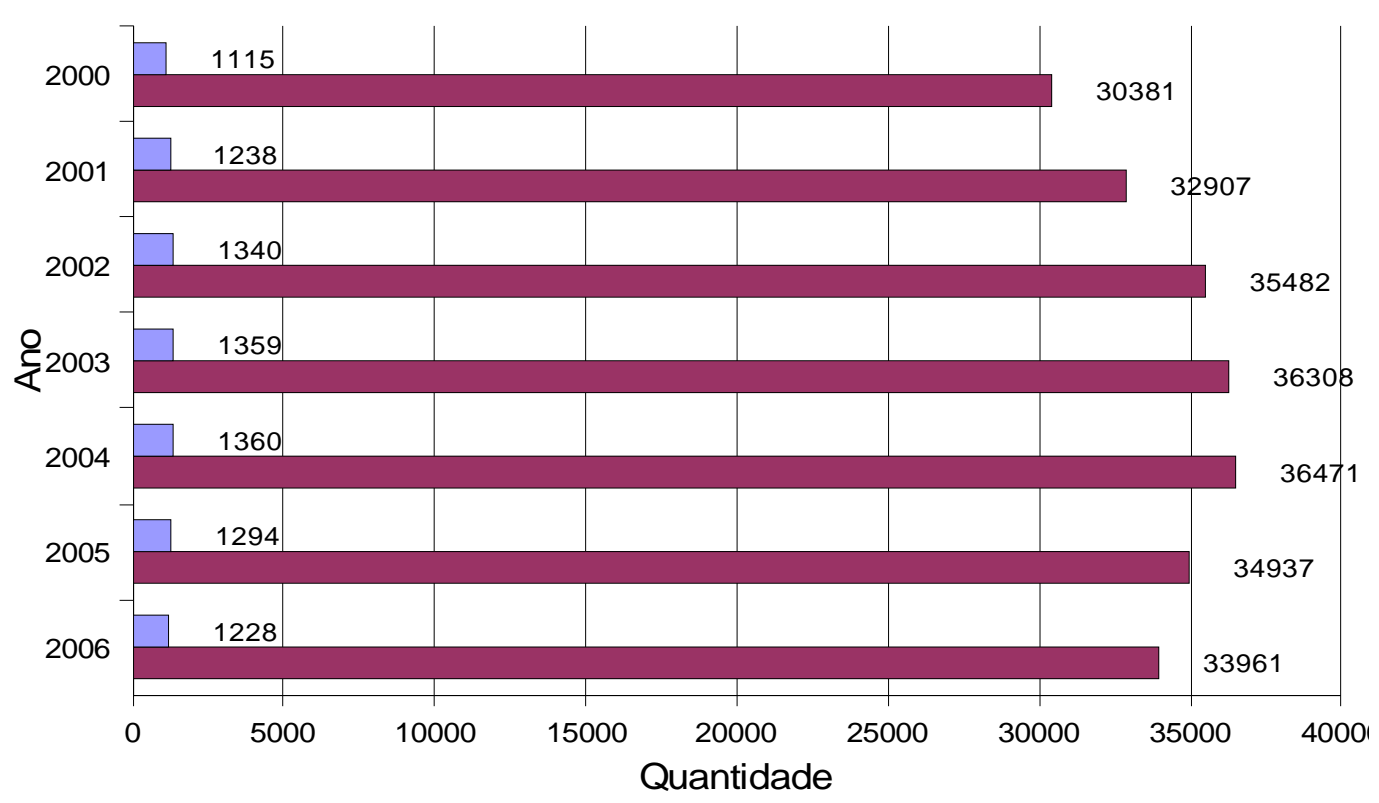

Fonte: SEPIN, 2008.

Figura 11 - Número de Docentes x Número de Alunos

A Figura 12 e demonstrado o número de escolas comparando ao número de salas de aula, visualizando melhor a relação existente entre os dois.

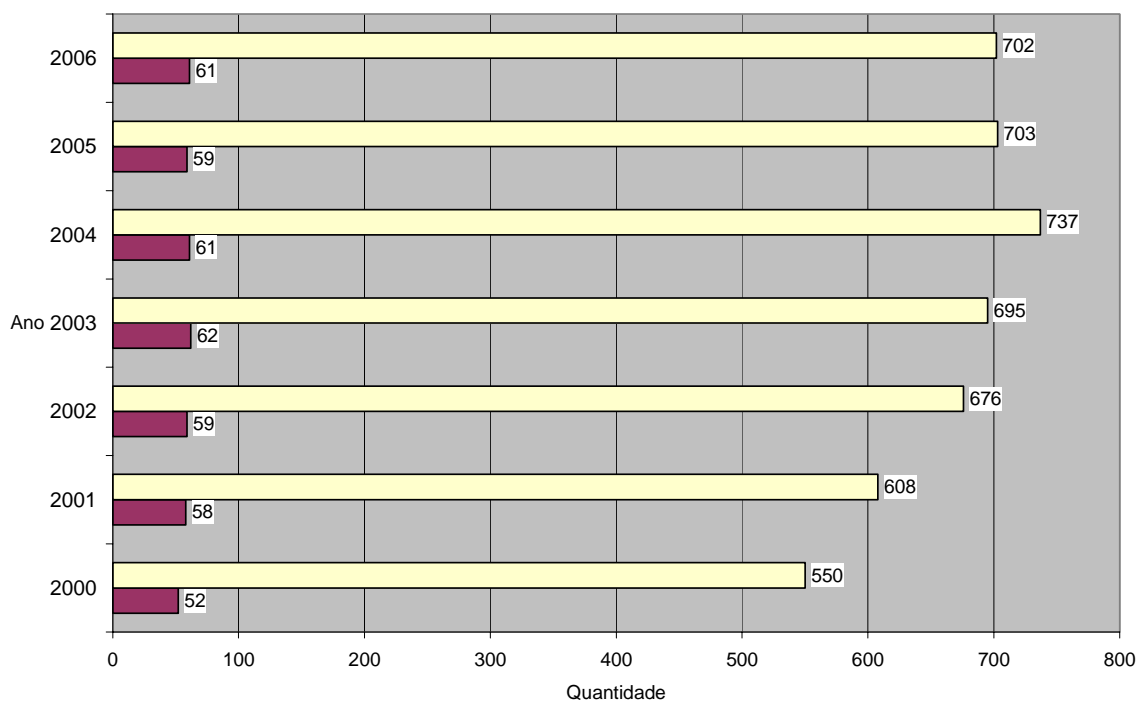

Fonte: SEPIN, 2008.

Figura 12 - Número de Escola x Número de Sala de Aula 
A distribuição de alunos em diferentes níveis de ensino, em Valparaíso de Goiás, é apresentada na Tabela 8.

Tabela 8 - Distribuição de alunos em diferentes níveis de ensino

\begin{tabular}{|c|c|c|c|c|c|c|c|}
\hline \multicolumn{8}{|c|}{ Distribuição de alunos em diferentes níveis de ensino } \\
\hline Ano & 2000 & 2001 & 2002 & 2003 & 2004 & 2005 & 2006 \\
\hline Alunos da Educação Pré-escolar & 2246 & 2090 & 2286 & 2245 & 2774 & 2744 & 2674 \\
\hline Alunos do Ensino Fundamental & 18133 & 19214 & 19832 & 19846 & 21667 & 20792 & 20957 \\
\hline Alunos do Ensino Médio & 4527 & 5703 & 6161 & 6043 & 6348 & 5878 & 5989 \\
\hline Alunos do Ensino Especial & 70 & 113 & - & - & 47 & 99 & 66 \\
\hline $\begin{array}{l}\text { Alunos da Educação de Jovens e } \\
\text { Adultos }\end{array}$ & 4252 & 4039 & 5020 & 5569 & 5057 & 4722 & 3850 \\
\hline $\begin{array}{l}\text { Alunos do Ensino Profissional (nível } \\
\text { técnico) }\end{array}$ & & & 409 & 623 & 317 & 501 & 146 \\
\hline Alunos da Creche & & 245 & 256 & 250 & 261 & 201 & 279 \\
\hline Alunos da Classe de Alfabetização & 1153 & 1503 & 1518 & 1732 & - & - & \\
\hline Total de Alunos & 30381 & 32907 & 35482 & 36308 & 36471 & 34937 & 33961 \\
\hline
\end{tabular}

Os alunos de ensino fundamental e médio seguem a mesma trajetória, apesar de seus valores serem distintos, enquanto que o ensino médio fica numa média de 6000 alunos por ano, o ensino fundamental chega a mais de 20000 alunos por ano. A educação de jovens e adultos cresce até 2003, quando chega ao ápice, diminuindo a partir de então. A educação pré-escolar por sua vez segue em um estado de estagnação, sem muitas variações.

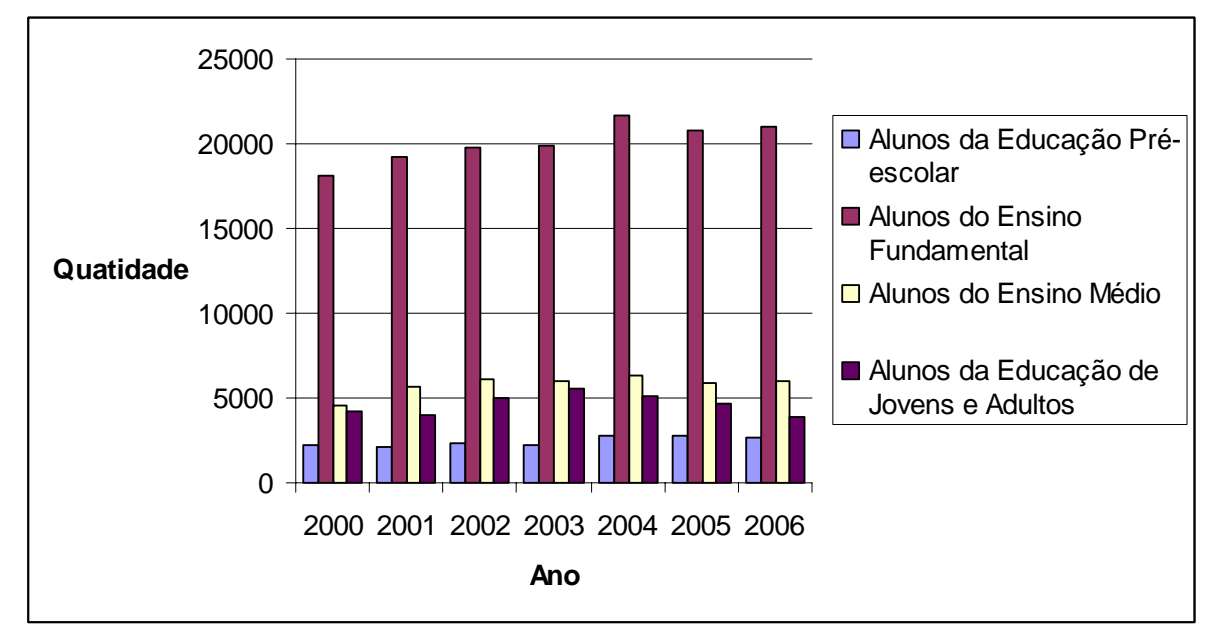

Fonte: SEPIN, 2008.

Figura 13 - Comparação de alunos em diferentes níveis de ensino 
Em relação ao ensino superior, em 2007, há três faculdades: Faculdade de Ciências e Educação Sena Aires (FACESA), Instituto de Ciências Socais e Humanas (ICSH) e Faculdade JK. A primeira e a segunda existem desde 2003, e a última foi estabelecida em 2005.

Para medir o acesso à educação em grandes sociedades, como um país, a taxa de matrícula nos diversos níveis do sistema educacional é um indicador suficientemente preciso. Quando o foco está em núcleos sociais menores, como municípios, esse indicador é menos eficaz, pois os estudantes podem morar em uma cidade e estudar em outra, distorcendo as taxas de matrícula. Daí a opção pelo indicador de freqüência à sala de aula, que é baseado em dados censitários. O que se pretende aferir é a parcela da população daquela cidade que vai à escola em comparação à população municipal em idade escolar.

Pelo calendário do Ministério da Educação, aos sete anos uma criança deve iniciar o primeiro ciclo do ensino fundamental. Aos 15 anos, o jovem deve ingressar na primeira série do ensino médio, e, aos 22 anos, concluir o ensino superior. Esse calendário indica que a maioria da população deveria estar envolvida no processo de ensino-aprendizagem entre as idades de 7 e 22 anos. Por isso, ao se avaliar o acesso das pessoas ao conhecimento, divide-se o total de alunos nos três níveis de ensino pela população total dessa faixa etária. A esse indicador se dá o nome de taxa bruta de freqüência escolar.

O outro critério para a avaliação da educação de uma população é o percentual de alfabetizados maiores de 15 anos. Ele se baseia no direito constitucional de todos os brasileiros de terem acesso às nove séries do ensino fundamental. A taxa de alfabetização é obtida pela divisão do total de alfabetizados maiores de 15 anos pela população total de mais de 15 anos de idade do município pesquisado. A taxa de alfabetização de Valparaíso de Goiás em 2000 é de 93,1\%, esta taxa é calculada com pessoas acima de 10 anos. 


\section{Economia}

A base de sua economia é mantida principalmente pelo comércio e pequenas indústrias, concentradas principalmente no ramo moveleiro, ou seja, na produção de móveis. Em 2006, por exemplo, a cidade contava com aproximadamente 100 unidades industriais e 600 estabelecimentos comerciais. Recentemente, tem aumentado a instalação de indústrias moveleiras na cidade, e, com isso, foi implantado um centro para mais de 120 novas fábricas.

Em relação à Balança comercial, Valparaíso de Goiás só efetua importações. O saldo, em 2007, foi de 34.606 .

A produção pecuária, apresentada na Tabela 9, é estável, pois num período de cinco anos é mínima a variação dos valores.

Tabela 9 - Efetivo da Pecuária

\begin{tabular}{|l|r|r|r|r|r|}
\hline \multicolumn{7}{|c|}{ Efetivo da Pecuária } \\
\hline Ano & 2002 & 2003 & 2004 & 2005 & 2006 \\
\hline Aves (cab) & 400 & 300 & 350 & 400 & 450 \\
\hline Bovinos (cab) & 380 & 600 & 700 & 600 & 700 \\
\hline Prod. De leite (1.000 I) & 65 & 86 & 101 & 72 & 108 \\
\hline Prod. De ovos (1.000 dz) & & 1 & 1 & 2 & 2 \\
\hline Suínos (cab) & 100 & 85 & 95 & 100 & 115 \\
\hline
\end{tabular}

Fonte: SEPIN, 2008.

Já a produção agrícola, que é basicamente de arroz e milho, teve uma drástica queda como apresentado na tabela 10, em intervalos de dois anos.

Tabela 10 - Produção Agrícola

\begin{tabular}{|l|r|r|r|r|r|r|}
\hline \multicolumn{7}{|c|}{ Produção Agrícola } \\
\hline Ano & \multicolumn{7}{|c|}{2000} & \multicolumn{2}{c|}{2002} & & 2004 \\
\hline Produtos & Àrea (há) & Prod. (t) & Àrea (há) & Prod. (t) & Àrea (há) & Prod. (t) \\
\hline Arroz - total & 45 & 148 & 90 & 65 & 3 & 3 \\
\hline Milho - total & 70 & 315 & 65 & 98 & 5 & 7 \\
\hline
\end{tabular}


Produto Interno Bruto (PIB) é a soma das riquezas produzidas em um país no decorrer de um ano, pelos diversos setores da economia (primário, secundário e terciário), sendo um dos principais indicadores mundiais do crescimento econômico dos paises. Em Valparaíso de Goiás, o número está em constante crescimento como representado na Tabela 11.

Na avaliação da renda dos habitantes de um município, o uso do PIB per capita torna-se inadequado. Por exemplo, nem toda a renda produzida dentro da área do município é apropriada pela população residente. A alternativa adotada é o cálculo da renda municipal per capita. Ela permite, por exemplo, uma desagregação por cor ou gênero da população, o que seria inviável de outra maneira.

Tabela 11 - Produto Interno Bruto (PIB) de Valparaíso de Goiás

\begin{tabular}{|l|l|l|l|l|l|l|l|}
\hline Produto Interno Bruto - PIB \\
\hline Ano & $\mathbf{1 9 9 9}$ & $\mathbf{2 0 0 0}$ & $\mathbf{2 0 0 1}$ & $\mathbf{2 0 0 2}$ & $\mathbf{2 0 0 3}$ & $\mathbf{2 0 0 4}$ & 2005 \\
\hline PIB (R\$1.000,00) & 129.233 & 160.905 & 178.755 & 259.882 & 296.128 & 337.109 & 377.154 \\
\hline PIB per capita (R\$,00) & 1.389 & 1.652 & 1.757 & 2.448 & 2.678 & 2.931 & 3.156 \\
\hline
\end{tabular}

Fonte: SEPIN, 2008

Sendo Valparaíso de Goiás uma cidade do entorno de Brasília, sua economia é menos privilegiada, dependendo do setor informal que representa cerca de $40 \%$ da base de trabalhadores, estando a grande maioria ocupada na construção civil. Porém é uma das cidades que participa da Região Integrada de Desenvolvimento do Distrito Federal e Entorno (RIDE) que é uma região integrada de desenvolvimento econômico, criada pela Lei Complementar $n^{\circ}$ 94, de 19 de fevereiro de 1998 e regulamentada pelo Decreto $n^{\circ} 2.710$, de 4 de agosto de 1998 , alterado pelo Decreto $n^{\circ} 3.445$, de 4 de maio de 2000, conforme Tabela 12: 
Tabela 12 - Região Integrada de Desenvolvimento do Distrito Federal e Entorno

\begin{tabular}{|c|c|}
\hline Estado & Goiás, Minas Gerais e Distrito Federal \\
\hline Lei & LC 94/1988 \\
\hline Data da Criação & 19 de fevereiro de 1988 \\
\hline Número de municípios & 21 mais o Distrito Federal \\
\hline Cidade Sede & Brasília \\
\hline PIB $\$ 86.360 .810$ mil \\
\hline Área & $55.434,99 \mathrm{~km}^{2}$ \\
\hline População & 3.451 .549 hab. \\
\hline \multicolumn{2}{|c|}{ Características Geográficas } \\
\hline
\end{tabular}

A Região Integrada de Desenvolvimento do Distrito Federal e Entorno (RIDE) é constituída pelo Distrito Federal, pelos municípios de Abadiânia, Água Fria de Goiás, Águas Lindas de Goiás, Alexânia, Cabeceiras, Cidade Ocidental, Cocalzinho de Goiás, Corumbá de Goiás, Cristalina, Formosa, Luziânia, Mimoso de Goiás, Novo Gama, Padre Bernardo, Pirenópolis, Planaltina, Santo Antônio do Descoberto, Valparaíso de Goiás e Vila Boa, no estado de Goiás, e de Unaí e Buritis, no estado de Minas Gerais. Ocupa uma região de 55.434,99 quilômetros quadrados e sua população se aproxima dos 3,5 milhões de habitantes.

O Imposto sobre Operações relativas à Circulação de Mercadorias e Prestação de Serviços de Transporte Interestadual e Intermunicipal e de Comunicação (ICMS) é um imposto estadual, ou seja, somente os Governos dos Estados do Brasil e do Distrito Federal têm competência para instituí-lo (Conforme: Art.155, II, da Constituição de 1988).

O principal fato gerador para a incidência do ICMS é a circulação de mercadoria, mesmo que inicie-se no exterior. Além disso, o ICMS incide sobre serviços de telecomunicação e transporte intermunicipais e interestaduais.

O simples fato de a mercadoria sair do estabelecimento de contribuinte já caracteriza o fato gerador. Não importa se a venda se efetivou ou não, mas sim se ocorreu a circulação da mercadoria; trata-se de uma situação de fato, não simplesmente de uma situação jurídica. 
A prestação de serviço de transporte, no âmbito intermunicipal e interestadual também caracteriza o fato gerador, bem como a prestação do serviço de telecomunicação. A arrecadação e distribuição do ICMS em Valparaíso de Goiás é mostrado nas Figuras 14 e 15.

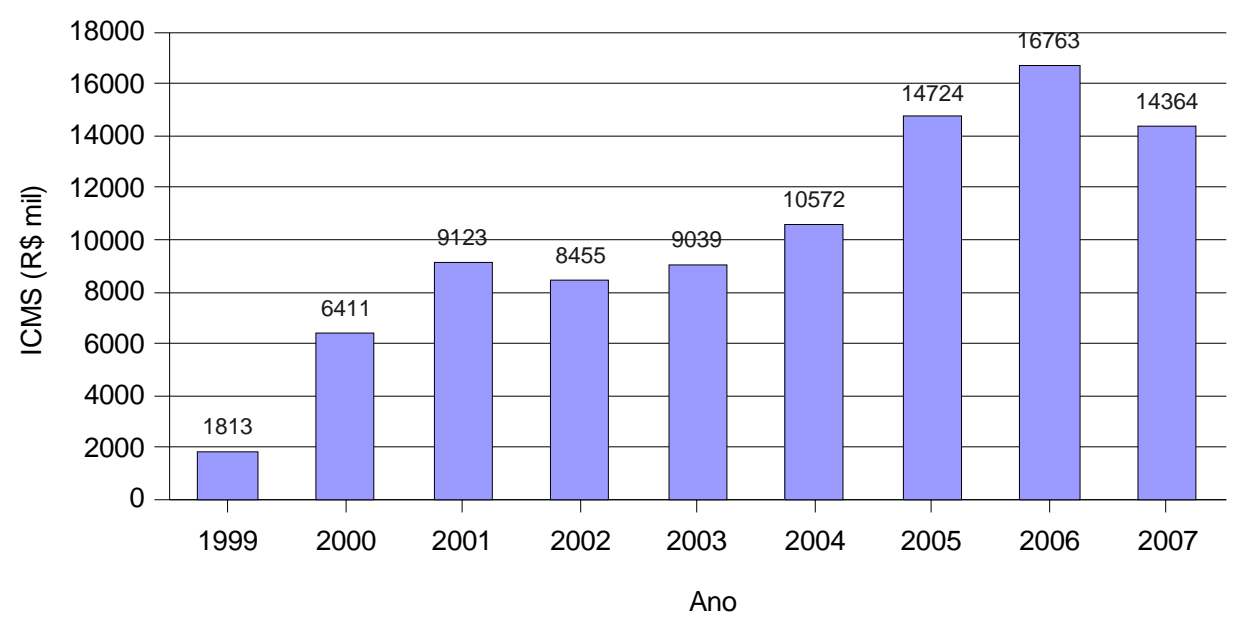

Fonte: SEPIN, 2008.

Figura 14 - Arrecadação do ICMS em Valparaíso de Goiás

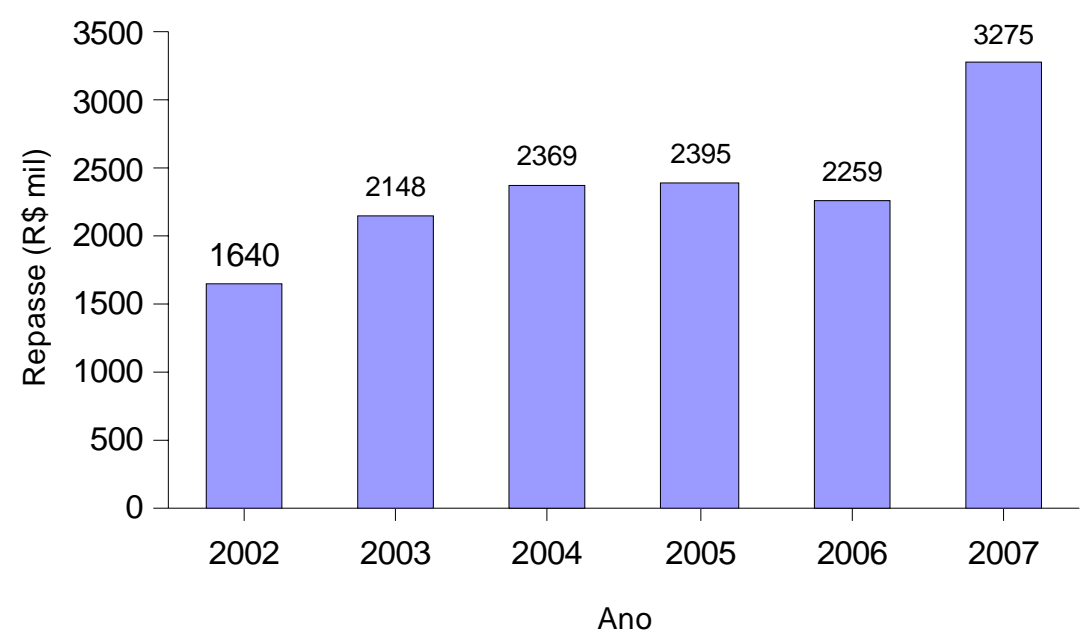

Fonte: SEPIN, 2008.

Figura 15 - Distribuição de ICMS em Valparaíso de Goiás 
Ainda analisando o aspecto financeiro de Valparaíso de Goiás, as receitas e despesas no período de 2003 a 2006 estão na Tabela 13, sendo que:

As despesas correntes são realizadas com a manutenção dos equipamentos e com o funcionamento dos órgãos, enquanto que as despesas de capital são realizadas com o propósito de formar e/ou adquirir ativos reais, abrangendo, entre outras ações, o planejamento e a execução de obras, a compra de instalações, equipamentos, materiais permanentes, títulos representativos do capital de empresas ou entidades de qualquer natureza, bem como as amortizações de dívida e concessões de empréstimos.

As receitas correntes são receitas que apenas aumentam o patrimônio não duradouro do Estado, isto é, que se esgotam dentro do período anual. São os casos, por exemplo, das receitas dos impostos que, por se extinguirem no decurso da execução orçamentária, têm, por isso, de ser elaboradas todos os anos. Compreendem as receitas tributárias, patrimoniais, industriais e outras de natureza semelhante, bem como as provenientes de transferências correntes. E as receitas de capital são receitas que alteram o patrimônio duradouro do estado, como, por exemplo, aquelas provenientes da observância de um período ou do produto de um empréstimo contraído pelo estado a longo prazo. Compreendem, assim, a constituição de dívidas, a conversão em espécie de bens e direitos, reservas, bem como as transferência de capital.

Tabela 13 - Receita e Despesa de Valparaíso de Goiás

\begin{tabular}{|l|r|rrr|r|}
\hline \multicolumn{5}{|c|}{ Receita e Despesa } \\
\hline & \multicolumn{1}{|c|}{2003} & 2004 & 2005 & \multicolumn{1}{c|}{2006} \\
\hline Despesas Correntes (R\$ mil) & 31568 & 35699 & 40433 & 53568 \\
\hline Despesas de Capital (R\$ mil) & 3852 & 6736 & 2135 & 8732 \\
\hline Receitas Correntes (R\$ mil) & 35164 & 40950 & 47765 & 56430 \\
\hline Receitas de Capital (R\$ mil) & 1270 & 4229 & 250 & 4673 \\
\hline Total de Receitas (R\$ mil) & 36434 & 45179 & 48015 & 61103 \\
\hline Total de Despesas (R\$ mil) & 35419 & 42435 & 42568 & 62300 \\
\hline
\end{tabular}




\section{Saneamento e Moradia}

Quanto ao Saneamento da cidade, as redes de água e esgoto são atendidas pela: Prefeitura, FUNASA e também por gestão autônoma. Os dados sobre extensão das redes de água e esgoto e da quantidade de ligação das mesmas são demonstrados na Tabela 14:

\begin{tabular}{|l|r|r|r|r|r|r|r|r|}
\hline \multicolumn{10}{|c|}{ Saneamento } & 2000 & 2001 & 2002 & 2003 & 2004 & 2005 & 2006 & 2007 \\
\hline Aguas-Extensão de Redes $(\mathrm{m})$ & 94.416 & 96.487 & 96.487 & 220.488 & 220.488 & 220.488 & 220.488 & 282.524 \\
\hline Água-Ligação $\left(\mathrm{n}^{\circ}\right)$ & 6.947 & 7.532 & 7.749 & 13.946 & 15.664 & 18.671 & 18.983 & 20.936 \\
\hline Esgoto-Extensão de Redes $(\mathrm{m})$ & 35.000 & 35.000 & 35.000 & 35.000 & 35.000 & 35.000 & 35.000 & 35.000 \\
\hline Esgoto-Ligação $\left(\mathrm{n}^{\circ}\right)$ & 3.553 & 3.573 & 4.460 & 4.583 & 4.801 & 6.144 & 6.462 & 7.095 \\
\hline
\end{tabular}

Tabela 14 - Saneamento

Fonte: SEPIN, 2008. 
O número de moradia em relação à quantidade de salários mínimos recebidos, ou seja, a renda familiar é representada pela Figura 16.

$2601 ; 11 \%$

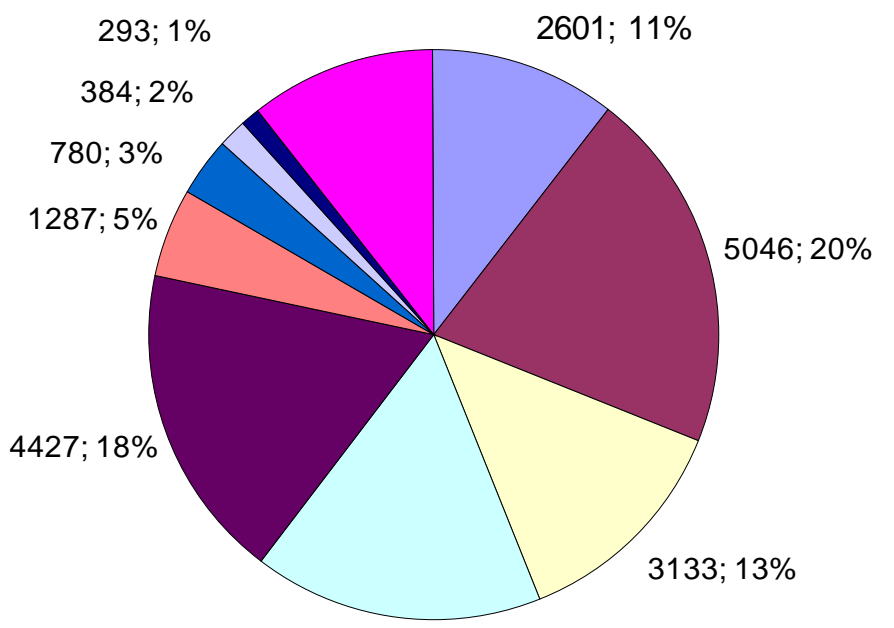

$3999 ; 16 \%$ $\square$ Até 1

Mais de 1 a 2

$\square$ Mais de 2 a 3

$\square$ Mais de 3 a 5

- Mais de 5 a 10

$\square$ Mais de 10 a 15

- Mais de 15 a 20

$\square$ Mais de 20 a 30

- Mais de 30

$\square$ Sem rendimento

\begin{tabular}{|l|r|}
\hline \multicolumn{2}{|c|}{ Legenda } \\
\hline Até 1 & 2601 \\
\hline Mais de 1 a 2 & 5046 \\
\hline Mais de 2 a 3 & 3133 \\
\hline Mais de 3 a 5 & 3999 \\
\hline Mais de 5 a 10 & 4427 \\
\hline Mais de 10 a 15 & 1287 \\
\hline Mais de 15 a 20 & 780 \\
\hline Mais de 20 a 30 & 384 \\
\hline Mais de 30 & 293 \\
\hline Sem rendimento & 2601 \\
\hline
\end{tabular}

Fonte: SEPIN, 2008

Figura 16 - Moradia x Salário Mínimo 
A maior quantidade de moradia está representada pela renda de um a dois salários mínimos (5056) atingindo 20\% de moradias, seguido da renda de cinco a dez salários mínimos (4427) que atinge a 18\%. Moram poucas pessoas que tem alta renda, pois os maiores valores são aqueles que têm de nenhum salário a 10 salários mínimos.

\section{Índice de Desenvolvimento Humano (IDH)}

O Índice de Desenvolvimento Humano foi criado originalmente para medir o nível de desenvolvimento humano dos países a partir de indicadores de educação (alfabetização e taxa de matrícula), longevidade (esperança de vida ao nascer) e renda (PIB per capita). O índice varia de 0 (nenhum desenvolvimento humano) a 1 (desenvolvimento humano total). Países com IDH até 0,499 têm desenvolvimento humano considerado baixo; os países com índices entre 0,500 e 0,799 são considerados de médio desenvolvimento humano; países com IDH maior que 0,800 têm desenvolvimento humano considerado alto.

Para aferir o nível de desenvolvimento humano de municípios as dimensões são as mesmas - educação, longevidade e renda -, mas alguns dos indicadores usados são diferentes. Embora meçam os mesmos fenômenos, os indicadores levados em conta no IDH municipal (IDHM) são mais adequados para avaliar as condições de núcleos sociais menores.

Para a avaliação da dimensão educação, o cálculo do IDH municipal considera dois indicadores, com pesos diferentes: taxa de alfabetização de pessoas acima de 15 anos de idade (com peso dois) e a taxa bruta de freqüência à escola (com peso um). $\mathrm{O}$ primeiro indicador é o percentual de pessoas com mais de 15 anos capaz de ler e escrever um bilhete simples (ou seja, adultos alfabetizados). O calendário do Ministério da Educação indica que se a criança não se atrasar na escola ela completará esse ciclo aos 14 anos de idade, daí a medição do analfabetismo se dar a partir dos 15 anos. O segundo indicador é resultado de uma conta simples: o somatório de pessoas (independentemente da idade) que freqüentam os cursos fundamental, secundário e superior é dividido pela população na faixa etária de 7 a 22 anos da localidade. Estão também incluídos na conta os alunos de cursos supletivos de primeiro e de segundo 
graus, de classes de aceleração e de pós-graduação universitária. Apenas classes especiais de alfabetização são descartadas para efeito do cálculo.

Para a avaliação da dimensão longevidade, o IDH municipal considera o mesmo indicador do IDH de países: a esperança de vida ao nascer. Esse indicador mostra o número médio de anos que uma pessoa nascida naquela localidade no ano de referência (no caso, 2000) deve viver. O indicador de longevidade sintetiza as condições de saúde e salubridade daquele local, uma vez que quanto mais mortes houver nas faixas etárias mais precoces, menor será a expectativa de vida observada no local.

Para a avaliação da dimensão renda, o critério usado é a renda municipal per capita, ou seja, a renda média de cada residente no município. Para se chegar a esse valor soma-se a renda de todos os residentes e divide-se o resultado pelo número de pessoas que moram no município (inclusive crianças ou pessoas com renda igual a zero). No caso brasileiro, o cálculo da renda municipal per capita é feito a partir das respostas ao questionário expandido do Censo - um questionário mais detalhado do que o universal e que é aplicado a uma amostra dos domicílios visitados pelos recenseadores. Os dados colhidos pelo Instituto Brasileiro de Geografia e Estatística (IBGE), através dessa amostra do Censo, são expandidos para o total da população municipal e, então, usados para o cálculo da dimensão renda do IDH-M.

Uma vez escolhidos os indicadores, são calculados os índices específicos de cada uma das três dimensões analisadas: IDHM-E, para educação; IDHM-L, para saúde (ou longevidade); IDHM-R, para renda. Para tanto, são determinados os valores de referência mínimo e máximo de cada categoria, que serão equivalentes a 0 e 1 , respectivamente, no cálculo do índice. Os sub-índices de cada município serão valores proporcionais dentro dessa escala: quanto melhor o desempenho municipal naquela dimensão, mais próximo o seu índice estará de 1. O IDHM de cada município é fruto da média aritmética simples desses três sub-índices: somam-se os valores e divide-se o resultado por três (IDHM-E + IDHM-L + IDHM-R / 3).

Em Valparaíso de Goiás, o Índice de Desenvolvimento Humano Municipal é demonstrado na Tabela 8, sendo que a classificação segundo o IDH: elevado seria de 0,800 e superior; médio de 0,500 a 0,799 e baixo seria abaixo de 0,500. 
Tabela 15 - Índice de Desenvolvimento Humano Municipal (IDH-M) de Valparaíso de Goiás

\begin{tabular}{|c|c|c|}
\hline \multicolumn{3}{|c|}{ Índice de Desenvolvimento Humano Municipal (IDH-M) } \\
\hline & 1991 & \\
\hline IDH-M & 0,739 & 0,795 \\
\hline IDH-M- Renda & 0,692 & 0,716 \\
\hline IDH-M- Educação & 0,837 & 0,902 \\
\hline IDH-M- Longevidade & 0,687 & 0,767 \\
\hline
\end{tabular}

O IDH do Município de Valparaíso de Goiás demonstra que a cidade tem um desenvolvimento médio nos indicadores de renda e longevidade, com exceção do indicador de educação que tem um nível elevado. 


\subsection{ONG - Sonhar Acordado}

Em março de 1998, na cidade de Monterrey, no México, nasceu o Soñar Despierto, como uma iniciativa de jovens que desejavam mudar a sociedade. Atualmente, com 10 anos de atividades, a ONG está presente em diversos países entre eles: Venezuela, Colombia, Chile, Argentina, Guatemala, El Salvador, Espanha, Irlanda, Itália, Estados Unidos e Brasil. No Brasil tem sede em São Paulo, mas também atua no Rio de Janeiro, Campinas, Fortaleza, Curitiba, Brasília, Maringá, Recife, Belo Horizonte e Porto Alegre.

O Sonhar Acordado é uma organização não governamental, fundamentada no voluntariado. Chegou ao Brasil no ano de 2000 por meio de um movimento religioso brasileiro que ao conhecer o trabalho da ONG Sonãr Despierto, entrou em contato com os responsáveis pela ONG no México que, animados com o entusiasmo dos brasileiros, enviaram todo o material de divulgação, além do estatuto da entidade, trazendo-a para o país.

Como marco inicial, a equipe do Rio de Janeiro realizou, no dia 16 de dezembro de 2000, uma grande Festa de Natal, envolvendo cerca de 1.000 pessoas, dentre estas 650 crianças e 300 voluntários. Depois das brincadeiras no Parque de Diversões, as crianças receberam das mãos do Papai Noel os presentes que haviam pedido de Natal. Seu sucesso se deve ao fato da ONG propor assistência aos mais carentes no que thes é mais caro: na formação, enquanto seres humanos, de valores e princípios éticos. Para esta ONG a educação informal ou cidadã é definida como: educar para a sociedade, mostrando algo inusitado e absolutamente indispensável diante da crise de valores dos tempos modernos.

Desde 2004, o Sonhar Acordado se fixou na cidade de São Paulo, tornando-a sede nacional da ONG. Com os três projetos contínuos (Amigos para Sempre, Sonhando Juntos e Preparando para o Futuro) e os dois projetos esporádicos (Dia de Sonho e Festa de Natal), a filial de São Paulo realizou mais de nove (9) grandes comemorações, auxiliando mais de 1.500 crianças carentes, além de inúmeros outros eventos mensais. 
O Sonhar acordado tem o interesse de envolver de forma efetiva a juventude a ajudar o próximo. E para isso cria projetos consistentes e eficazes que tem o poder de agregar pessoas dispostas a fazer o bem e ajudar na formação e no desenvolvimento de uma nova sociedade. É composta de grupos de jovens, estudantes e profissionais recém formados das mais diversas áreas, que procuram dar o melhor de si, adequando as necessidades da juventude ao trabalho filantrópico realizado. Esses colaboradores doam seu tempo e seu esforço em prol de projetos movidos pela vontade de ajudar o próximo, de realizar sonhos, não só os das crianças, mas também o seu próprio: que é "a construção de uma sociedade melhor e mais justa".

A ONG Sonhar Acordado atua junto a crianças carentes, buscando prover-lhes valores importantes para a formação de qualquer cidadão, bem como suscitar e fomentar na juventude o senso e a necessidade do voluntariado.

Os objetivos, a missão e a visão de futuro da ONG estão explicitados, tendo como fonte o site da ONG Sonhar Acordado (2008):

\section{Objetivos}

a) Promover valores humanos, desenvolvendo o indivíduo, especialmente os que se encontram mais desprotegidos: as crianças.

b) Envolver o maior número possível de jovens nos projetos em favor das crianças mais necessitadas despertando na juventude uma consciência social muitas vezes adormecida, e impulsionando uma postura ativa no que diz respeito às necessidades do próximo e do nosso país.

c) Aproximar os voluntários da realidade das crianças, para que, possam ajudá-las a resgatar sua esperança e para que sirvam como verdadeiro exemplo a ser seguido.

d) Criar laços de amizade e solidariedade entre as crianças os voluntários, ressaltando o verdadeiro sentido da caridade e ensinado que no dar, está o receber.

e) Atuar de forma efetiva em comunidades e instituições próximas, onde seja detectada situação de carência, enriquecendo o ambiente onde crianças e adolescentes passam o seu dia-a-dia. 


\section{Missão}

"Nossa missão é formar, educar e ajudar a infância mediante atividades sociais, culturais, desportivas e recreativas, complementando a educação formal dessas crianças em sua maioria deficitária em termos de formação humana."

\section{Visão de Futuro}

"Ser agente de transformação da sociedade através da promoção de valores humanos, envolvendo para tanto o maior número possível de jovens nos projetos em favor das crianças mais carentes. Ser uma ONG de jovens com grande representatividade no Brasil, com programas eficazes em cada uma de suas filiais, organizando parcerias sólidas com empresas e pessoas que compartilhem dos mesmos ideais."

\section{Perfil dos voluntários}

O Sonhar Acordado é uma ONG de jovens, e tem como um de seus objetivos transformar os voluntários em jovens líderes, ajudando a infância de crianças carentes da cidade.

A fim de conhecer o perfil de seus voluntários O Sonhar Acordado - São Paulo realizou no Dia de Sonho, dia 8 de junho de 2008, uma pesquisa cujo resultado é apresentado a seguir.

Quanto à idade dos voluntários, grande parte está entre 15 e17 anos, conforme Figura 17: 


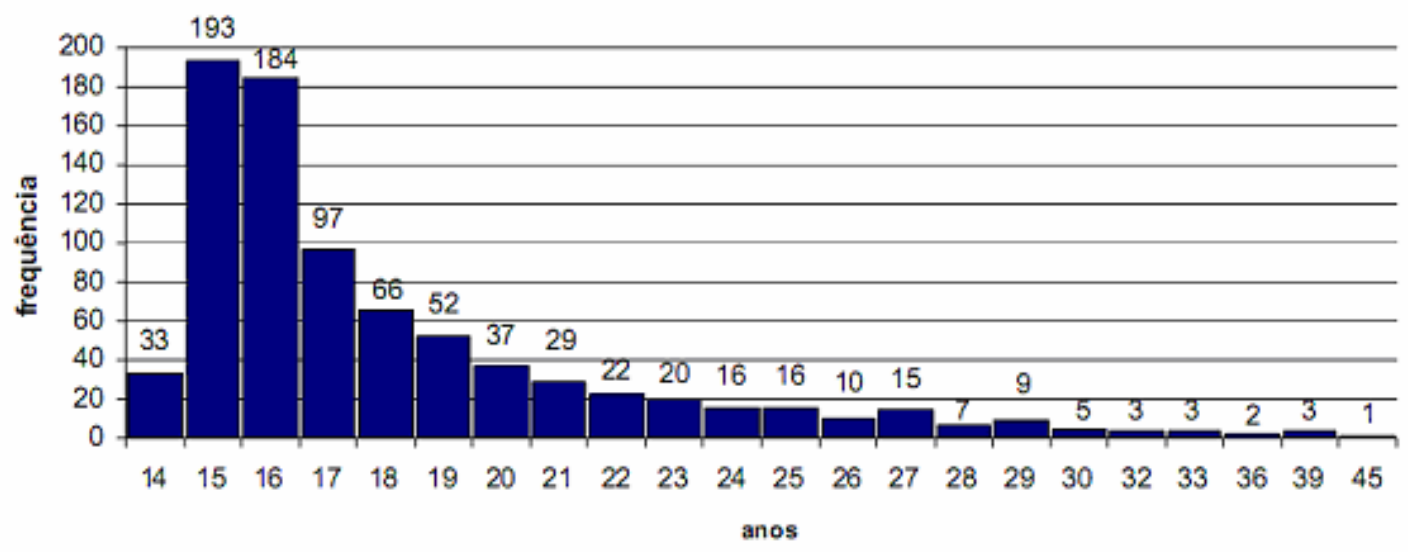

Fonte: Sonhar Acordado 2008.

Figura 17 - Idade dos Voluntários

A ONG tem como um de seus objetivos, transformar jovens líderes voluntários, e por isso atrai, cada vez mais, jovens de 15 a 30 anos que possuam interesse em doar parte de seu tempo ao trabalho voluntário.

O elevado número de jovens entre 14 e 17 anos representam 61,6\% dos voluntários presentes, fator que foi visto após a ONG realizar parcerias com colégios e alunos do Ensino Médio, que abraçaram o projeto, em Brasília o elevado número de voluntários está entre 17 e 22 anos de idade.

Outra grande parcela dos voluntários, entre 18 e 22 anos (25\%), são em grande maioria alunos de faculdades, que criaram por meio de uma divulgação local, em pouco tempo, adquiriram grande parte do corpo de voluntários.

Os demais voluntários representam 13,4\%, distribuídos entre 23 e 45 anos, e conheceram o projeto por meio de empresas que divulgaram o evento, amigos, Internet, e-mail, marketing, ou participaram alguma vez dos seus projetos: Amigos para Sempre, Sonhando Juntos, Preparando para o Futuro, Dia de Sonho e Festa de Natal.

Quanto ao local de trabalho do voluntário, a pesquisa indica: 


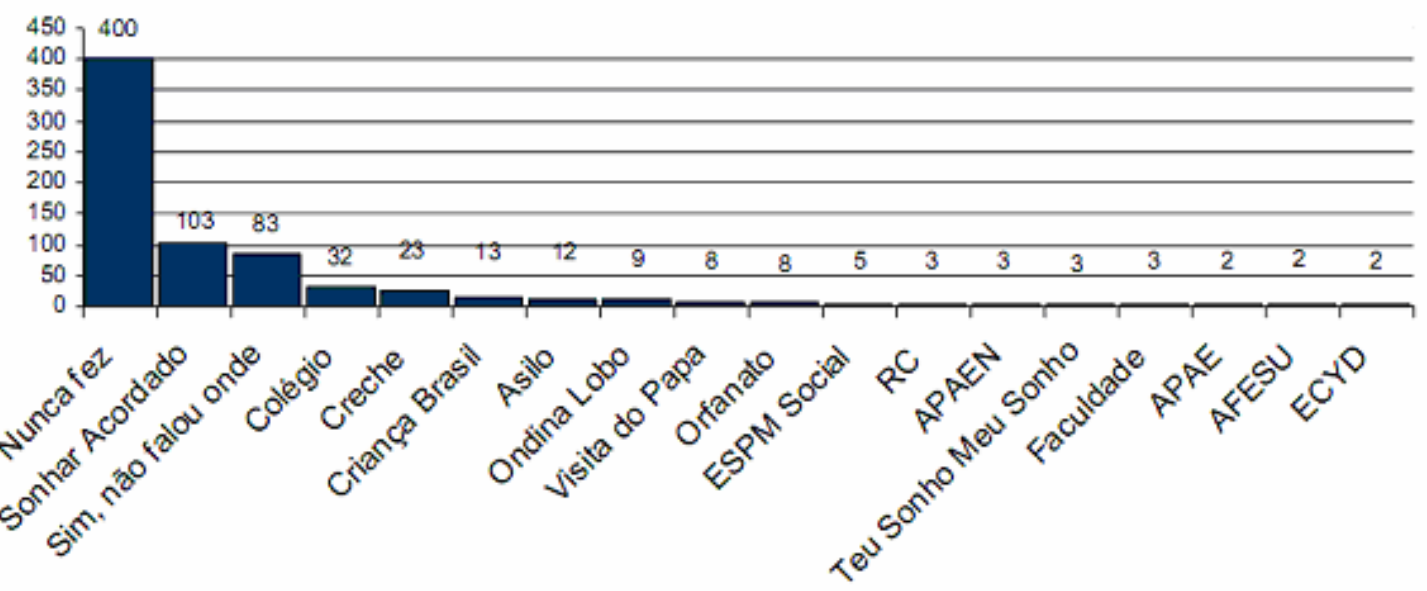

Fonte: Sonhar Acordado, 2008.

Figura 18 - Local de Trabalho Voluntário

Quando questionados sobre a participação em trabalhos voluntários, a maioria dos entrevistados $(48,6 \%)$ afirmou que nunca havia feito algum trabalho voluntário. Grande parte dos jovens já havia participado de algum evento da ONG Sonhar Acordado representando $12,5 \%$.

Os demais que fizeram trabalho voluntário estão divididos em atividades em outros colégios, faculdades, em creches, orfanatos, asilos e outras instituições, com ajudas pontuais e trabalhos não contínuos.

\section{Projetos}

Os projetos da ONG estão divididos em duas frentes, os Projetos Contínuos e os Projetos Esporádicos.

Os projetos contínuos são aqueles em que os voluntários, no período de um ano, atuam uma vez ao mês a fim de propiciar momentos únicos para as crianças. São eles: Amigos para Sempre, Sonhando Juntos e Preparando para o Futuro. 


\section{PROJETOS CONTÍNUOS:}

\section{Amigos para Sempre}

Amigos para Sempre é um projeto mensal, onde jovens têm contato com as crianças para criar um laço de amizade. As atividades ocorrem sempre em um sábado do mês, possuem caráter esportivo, cultural e recreativo e permitem aos jovens voluntários e crianças estabelecerem uma forte relação. Estas atividades podem ser realizadas em museus, parques, teatros, cinemas, de acordo com o recurso financeiro proposto para o evento, porém sair do ambiente não é o foco do trabalho, ele é feito in loco. As atividades são feitas para tentar envolver as crianças em torno de um determinado valor.

Com esse projeto o jovem torna-se responsável por apoiar e transmitir valores à criança, ajudando-a na maneira do possível, inclusive no desempenho escolar. É uma relação de amizade, que proporciona uma troca entre a criança e o voluntário, permitindo o crescimento e desenvolvimento de ambos. Durante as atividades, os voluntários e as crianças são divididos em grupos, nos quais cada um faz atividades previamente estabelecidas, com a finalidade de passar um valor onde um representante da ONG é responsável por supervisionar, dar suporte à equipe e entregar um relatório sobre o trabalho do dia ao coordenador de voluntários.

O objetivo do projeto "Amigos para Sempre" é oferecer uma referência em relação aos valores humanos e despertar nos jovens os valores de amizade, responsabilidade, disciplina, verdade, justiça, superação e honestidade.

O trabalho desenvolvido pelo grupo "Amigos para Sempre" de Brasília é uma atividade teatral, desenvolvida para transferir valores éticos, cívicos e sociais para as crianças. Utilizam a Hora do Conto como um recursos para que o objetivo principal do projeto seja alcançado. O grupo encontrou na dramatização uma forma de chamar a atenção das crianças. E usam além dos contos, outras formas de apresentações, desde a apresentação de textos informativos até breves tutoriais para as crianças e os jovens. 
É importante ressaltar que a popularidade das marionetes deve-se à uma série de aspectos determinantes com os quais as crianças se identificam, pois geralmente os personagens são crianças também, com a faixa etária semelhante à média de idade das crianças do Orfanato Lar Rita de Cássia. O que faz com que a curiosidade delas em relação à "vida particular" dos bonecos seja aguçada, possibilitando que aquelas venham a fazer perguntas sobre o cotidiano do personagem, desenvolvendo o lado lúdico das crianças.

\section{Sonhando Juntos}

Este projeto realiza atividades procurando levar alegria e descontração às crianças com algum tipo de enfermidade, o trabalho realizado em São Paulo, geralmente é focado nas crianças com doenças degenerativas. Os voluntários buscam realizar os sonhos destas e propiciar um momento de alegria e acender em suas famílias a esperança.

Os objetivos deste projeto são:

a) Levar esperança e alegria às crianças doentes, através de atividades recreativas.

b) Transformar a vida da criança, mesmo que por apenas um dia, fazendo com que se sinta a mais especial do mundo, e esqueça mesmo que por alguns instantes, todos os sofrimentos pelos quais já passou.

c) Dar apoio às famílias, para que nos momentos de maior dificuldade não se desestruturem, entendam e superem da melhor maneira possível, a dor e o medo da perda.

\section{Preparando o Futuro}

É um projeto ambicioso que visa à formação de jovens adolescentes em situação de risco social, tanto no aspecto profissional, quanto humano. Seu objetivo é orientar o jovem carente de acordo com o programa de Aprendizado Mirim, e segundo os princípios de direitos e valores humanos (com base no art. 428 da CLT) procurando deixar o jovem pronto para sua inserção no mercado de trabalho e na vida. 


\section{PROJETOS ESPORÁDICOS:}

Os projetos esporádicos são realizados duas vezes ao ano, ao final de cada semestre, e contam com a presença de um número maior de crianças e voluntários, podem ser realizados passeios também. São consideradas "Grandes Festas". Existem atualmente três projetos esporádicos: Dia do Sonho, Festa de Natal e SuperAção, conforme descrição a seguir:

\section{Dia do Sonho}

O Dia do Sonho nasceu para dar uma dimensão mágica ao primeiro contato entre a criança e o voluntário. Este dia é transformado em uma grande festa, onde os grupos de voluntários interagem com as crianças por meio de brincadeiras nas quais são transmitidos sentimentos e valores necessários à formação das crianças. Neste dia aproximadamente 1.000 crianças e 500 voluntários passam um dia inesquecível. Em 2006, 2007 e 2008 o Dia de Sonho foi realizado no Parque de Diversões Hopi Hari, em São Paulo, e ficou na memória de mais de 2.600 pessoas que participaram do evento.

\section{Festa de Natal}

É uma festa com todos os elementos típicos do Natal, desde o nascimento de Cristo à renovação do desejo de respeito mútuo, de paz e felicidade a todos. Este trabalho é iniciado meses antes, quando os voluntários se organizam em equipes para visitar as instituições e anunciar às crianças o dia da tão esperada festa. Neste momento os voluntários ajudam as crianças a escreverem as cartinhas, nas quais elas têm a oportunidade de contar um pouco da sua realidade e de seus sonhos. No dia da festa os voluntários buscam realizar os sonhos descritos nas cartinhas. As crianças participam de uma festa de Natal única, onde, envolvidas em uma atmosfera de sonho, assistem a shows, se divertem, participam de oficinas educativas e recebem o carinho e 
a atenção dos voluntários. No fim da festa as crianças recebem um presente especial das mãos do Papai Noel.

\section{SuperAção}

Campanhas e atividades periódicas são realizadas nas comunidades, em instituições ou colégios, com o objetivo de aliar a promoção de valores à necessidade de humanizar o ambiente em que as crianças vivem. Para tal, jovens voluntários planejam e realizam ações pontuais, junto a profissionais especializados, que podem ser de cunho educacional, institucional, recreativas ou ligadas às áreas de saúde.

Cada projeto da ONG existe com uma finalidade determinada. No caso do SuperAção - Brasília, o objetivo é identificar problemas que existam nos estabelecimentos atendidos pelo Sonhar Acordado e por meio da formação de grupos de pessoas que tenham formação técnica na situação determinada, conseguir solucionar o problema. Em específico na Frente de Leitura, o objetivo principal é o de estabelecer um programa de incentivo à leitura contínuo, implementando reformas, revitalizações e criando espaços destinados à esta atividade, bem como, a inserção de uma rotina de leitura e de desenvolvimento intelectual dos usuários destes ambientes.

Em Brasília a ONG a tua nas seguintes instituições:

a) Creche João de Barro, 40 crianças - Quadra 17 casa 94 Setor Leste, Gama

b) Orfanato Lar Rita de Cássia, aproximadamente 50 internos - Quadra 16 It. 1 Setor de Chácaras Anhanguera C, Valparaíso II - GO

c) Creche Criança Cidadã, 30 crianças - Quadra 7 Conjunto H Lote 6, Varjão

d) Centro Comunitário da Criança, 200 crianças - EQNP 9/13 módulo B/D, Ceilândia

e) Escola Novo Caminhar, 90 crianças e adolescentes - EQNP 22/26 Área Especial G Setor P Sul, Ceilândia

f) Creche Nosso Lar, 16 crianças - SAIS BL C lote 29, Núcleo Bandeirante

g) Lar São José, 45 crianças - QNM 32 Módulo B Área Especial, Ceilândia

h) Casa da Harmonia, 40 crianças - QNN 30 Módulo E Área Especial Guariroba, Ceilândia

i) Missionárias da Caridade, 106 crianças - QS 405 conjunto 1 lotes 1-4, Samambaia 
j) Instituto de difusão do Evangelho, 26 crianças - QS 111 conjunto 6 lote 2, Samambaia

k) Hospital Regional da Asa Sul, de 60 a 120 crianças atendidas - GAS quadra 608; módulo A - Brasília

I) Casa de Apoio Menino Jesus, 15 crianças - EQ 14/18 - Setor Oeste - Gama

\subsection{Orfanato Lar Rita de Cássia}

O Lar Rita de Cássia é uma entidade filantrópica, sem fins lucrativos, que se propõe a prestar assistência social integral às crianças carentes, órfãos e/ou abandonadas, proporcionando-Ihes: moradia em tempo integral, alimentação, cuidados médicos, educação, amor e outros valores que venham a se relacionar ao bem estar dessas crianças. Consideram-se "Uma família, que em nome de DEUS, junto a outros voluntários tentamos amenizar o sofrimento dessas crianças." (LAR RITA DE CÁSSIA, 2008).

Em meados de 1988, a senhora Pastora Alves Custodio Rodrigues, mais conhecida como Dona Pastora, naquela época com 43 anos, acolheu a menina Bruna de dois anos e três meses para cuidar por apenas 10 dias a pedido de sua mãe. Após os 10 dias a mãe da criança não apareceu e Dona Pastora comunicou o fato ao Conselho Tutelar. Naquela ocasião, ela não sabia, mas estava iniciando um belo trabalho filantrópico. Passado um ano a mãe de Bruna foi buscá-la, porém a criança recusou ficar com sua mãe, preferindo a senhora que cuidou dela durante aquele ano.

Em 1990, a menina Doralice chega ao Valparaíso de Goiás com sério problema de desnutrição e sua mãe a entrega aos cuidados de Dona Pastora que, também, comunica o fato ao Conselho Tutelar. Assim, Dona Pastora criou fama na região e no Conselho Tutelar, a partir daí o próprio Conselho Tutelar começou a enviar para a Dona Pastora crianças abandonadas ou violentadas por suas famílias, nascendo assim o Orfanato Lar Rita de Cássia. 


\subsubsection{Situação atual do Lar Rita de Cássia}

No início, a sede do Orfanato era no Jardim Oriente QE 23 lote 7 - Valparaíso de Goiás. Em 1998, o Orfanato Lar Rita de Cássia mudou-se para um lote maior na Quadra 16, Lote 1, Setor de Chácaras Anhanguera "C" - Valparaíso de Goiás, graças a doações do lote ao cimento.

A casa tem $300 \mathrm{~m}^{2}$ de área construída com dois dormitórios, um masculino e um feminino, dois banheiros (masculino e feminino) sala de TV, recepção, cozinha, lavanderia, quarto da presidente de honra e fundadora Dona Pastora, sala de computação, antigo refeitório, área coberta onde são feitas as refeições e o lazer das crianças, biblioteca, e a sala para atendimento clínico e odontológico, conforme Figura 19:

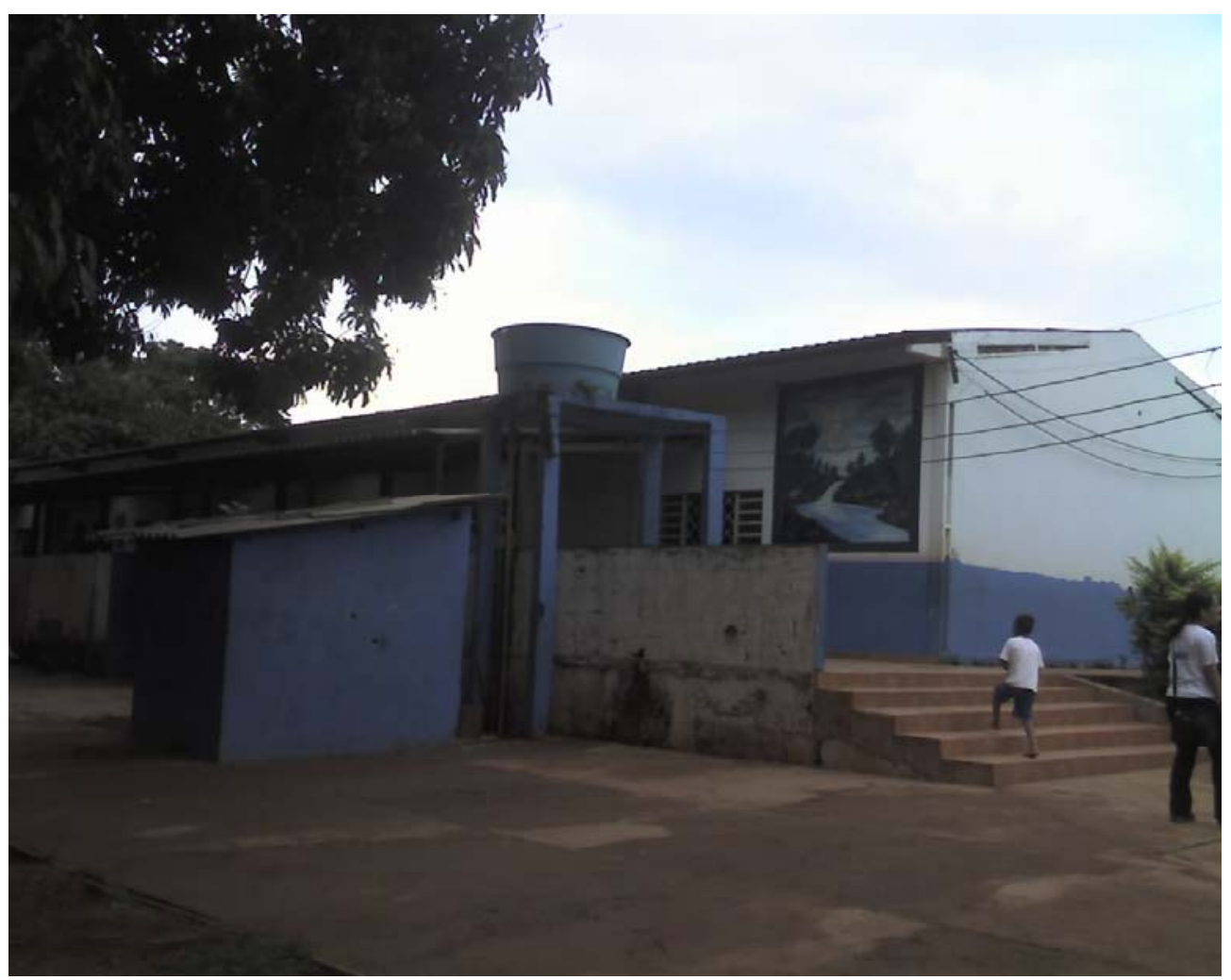

Figura 19 - Orfanato Lar Rita de Cássia

O Orfanato Lar Rita de Cássia é uma entidade filantrópica que não recebe nenhum tipo de ajuda do governo seja ele federal, estadual ou municipal. A instituição 
não tem nenhum tipo de renda própria, dependendo unicamente da ajuda e doações de voluntários. O orfanato não tem condições financeiras de ter funcionários, mas conta com a ajuda da senhora Jase e do senhor Messias que a mais de 10 anos ajudam constantemente a Dona Pastora em seu trabalho com as crianças, recebendo como gratificação o amor e carinho de todos do orfanato.

O Orfanato Lar Rita de Cássia, durante a semana cuida de crianças da vizinhança enquanto seus pais trabalham, realizando atividades de creche também, ou seja, algumas crianças freqüentam o Orfanato sem morar no local.

Atualmente, o Orfanato Lar Rita de Cássia atende 50 Crianças, mas este número pode variar para mais ou para menos em alguns meses, quando as crianças são reintegradas às suas famílias, ou novas crianças chegam ao Orfanato por meio do Conselho Tutelar. Nas Figuras 20 e 21 pode-se observar o perfil dos internos:

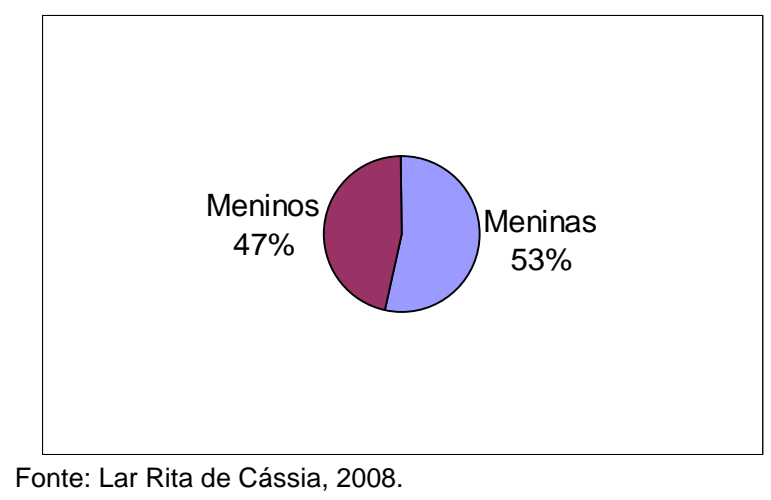

Figura 20 - Crianças do Orfanato por sexo

A maior parte dos internos são meninas (53\%). Com relação a idade, a Figura 21 retrata a sua distribuição:

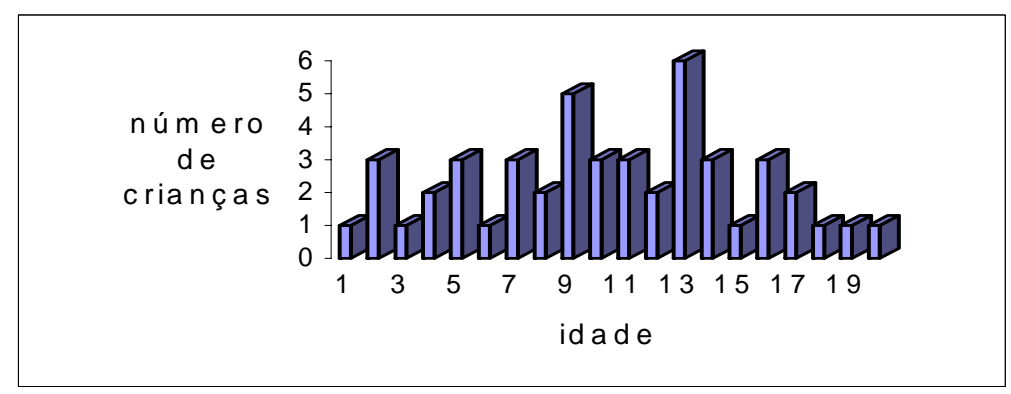

Fonte: Lar Rita de Cássia, 2008.

Figura 21 - Número de crianças por idade 
De acordo com a senhora Jase todas as crianças a partir de 5 anos estão matriculadas na escola, a maioria (70\%) estuda na escola Castro Alves que se localiza perto do orfanato, sendo possível ir a pé, os demais (30\%) que estudam em outras escolas perto do Orfanato Lar Rita de Cássia, também vão a pé para escola. Segundo a Dona Pastora, o rendimento escolar dos internos é insatisfatório, porém, o índice de reprovação é baixo.

Como o Orfanato Lar Rita de Cássia é uma família, e em toda a família existe cooperação, as crianças maiores ajudam em pequenas tarefas como: reunir os brinquedos que usam, arrumar a cama, e ajudar uns aos outros nas tarefas escolares. Essas atividades variam de acordo com a idade do interno e são comuns as atividades que outras crianças desempenham em seus lares.

Embora seja um orfanato, raramente ocorrem adoções dessas crianças uma das dificuldades é porque os internos estão no orfanato com seus irmãos, e em caso de adoção, as pessoas interessadas em adotar uma criança obrigatoriamente precisam adotar seu irmão ou irmãos. Como no Orfanato Lar Rita de Cássia é comum ter três ou mais irmãos de uma mesma família, o processo de adoção torna-se complicado, e mesmo se a pessoa interessada em adotar uma criança decidisse a adotá-la com seus irmãos, precisaria da permissão de seus pais. Estes chegam até a visitar seus filhos no orfanato, mas quando eles estavam em sua guarda os maltratavam e, talvez por um sentimento de posse, não tendo interesse de que seus filhos sejam adotados. Esses são os principais fatores pela baixa ou quase nenhuma incidência de adoção no Orfanato Lar Rita de Cássia.

Existe apenas um caso no Orfanato Lar Rita de Cássia de uma criança sem família: um menino, com aproximadamente 14 anos, cursando a oitava série do ensino fundamental que foi abandonado na rua pela sua mãe, ainda muito pequeno. $O$ Conselho Tutelar encaminhou-o para o Orfanato Lar Rita de Cássia, e não se sabe quem são seus pais, quantos anos têm, nem quando é seu aniversário e, por mais improvável que possa parecer é um indigente, pois até hoje não tem registro de nascimento. De acordo com a Dona Pastora ele só está na escola porque o Conselho Tutelar enviou um documento à escola pedindo que o matriculassem. 


\subsubsection{A importância das Doações e dos Voluntários}

De acordo com o site da organização, o orfanato precisa de material de construção para concluir as edificações e reformas da Instituição; gêneros alimentícios: perecíveis ou não; produtos de limpeza e higiene pessoal; utensílios de cozinha ou do lar; e a ajuda relativa à assistência educacional e profissional dos menores, tais como: doação de livros e material didático. Para o orfanato qualquer colaboração por menor ou menos importante que possa parecer faz grande diferença para a vida das crianças. A ajuda pode ser por: trabalhos dentro da habilidade profissional e capacidade de cada voluntário; visitas ao orfanato transmitindo amor, carinho e valores para as crianças; e a ajuda financeira, conforme Figura 22:

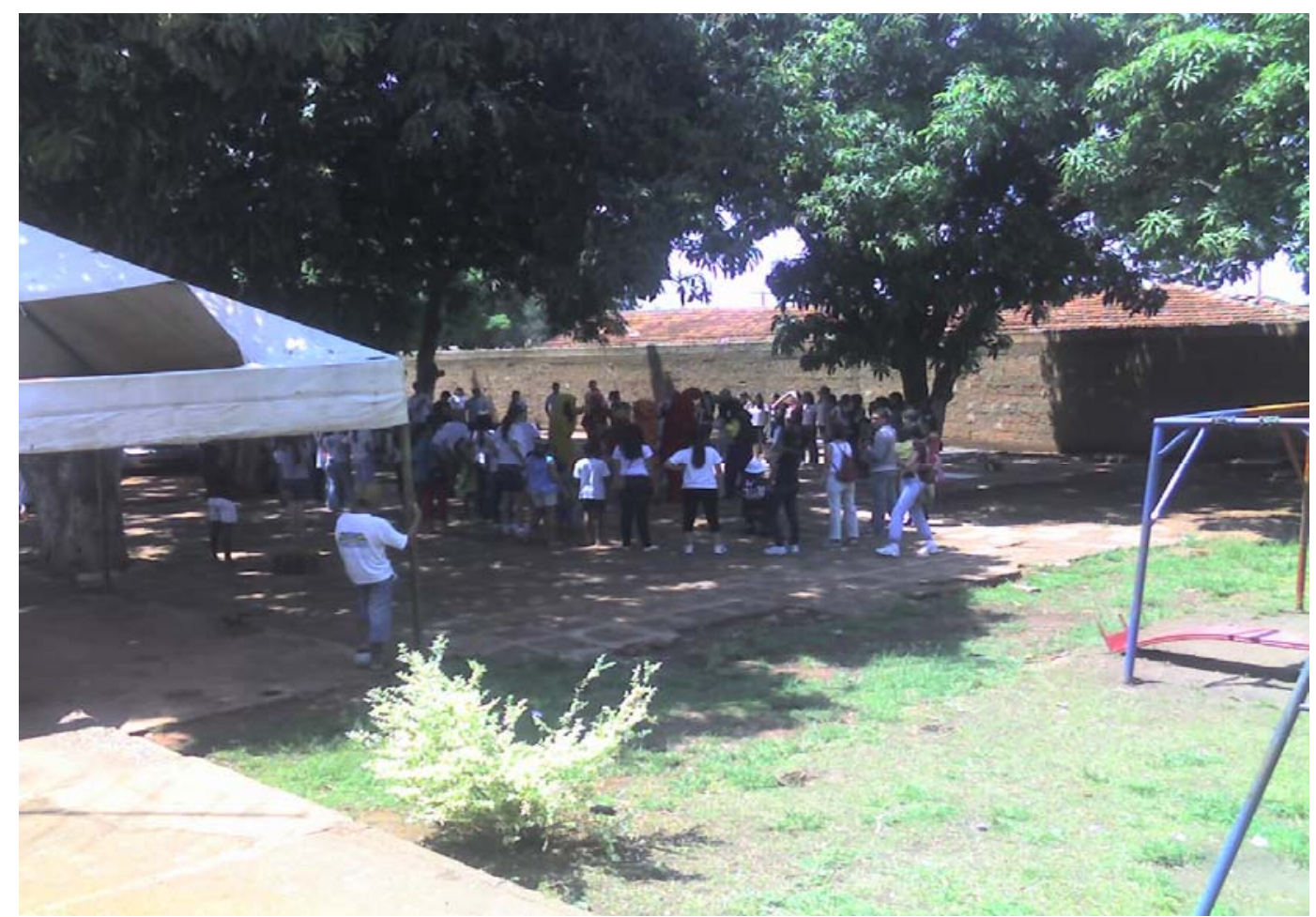

Figura 22 - Trabalho voluntário no Orfanato

O orfanato tem como objetivo capacitar às crianças para quando vierem a deixar o orfanato a estarem aptas para o mercado de trabalho. O voluntário instruído em sua área de conhecimento pode ajudar a instituição a alcançar este objetivo. 
A instituição tem a consciência de que voluntários com qualificações específicas são muito necessários para as entidades que não têm recursos para contratar administradores, advogados, gerentes financeiros, bibliotecários, médicos, psicólogos entre outros. Por isto, elas precisam de uma rede de profissionais previamente cadastrados, aos quais elas possam recorrer quando necessário, pois os profissionais agregam muito mais valor às instituições. O Sonhar Acordado e seus voluntários atendem a esses requisitos, pois busca agregar valores a formação das crianças e adolescentes do Orfanato Lar Rita de Cássia.

\subsection{Biblioteca do Orfanato Lar Rita de Cássia}

A Biblioteca do Orfanato Lar Rita de Cássia surgiu a partir de doações de livros e posteriormente com a reforma de uma sala, no mesmo lote do orfanato mas a poucos metros da casa, seu acervo é todo composto por doações de voluntários que preocupados com a aprendizagem, formação profissional e entretenimento dos internos doam: livros, revistas, gibis, brinquedos, jogos entre outros.

Devido à informalidade dessas atividades, não se sabe ao certo quando a sala, depósito de livros, tornou-se a biblioteca do orfanato. Da mesma forma que seu espaço ainda não foi quantificado.

Atualmente, a Biblioteca é composta de duas salas, a biblioteca e seu depósito. A Biblioteca é bem iluminada com quatro (4) janelas, três (3) lâmpadas "grandes" disposta paralelamente, facilitando e aumentado a confortabilidade do leitor, o telhado é forrado dificultando a incidência de goteiras e as paredes, portas e chão (de cerâmica) estão em boas condições de uso. Enquanto o depósito da biblioteca tem todas as qualidades da Biblioteca, exceto que seu espaço é menor e tem apenas uma (1) janela, conforme Figura 23. 


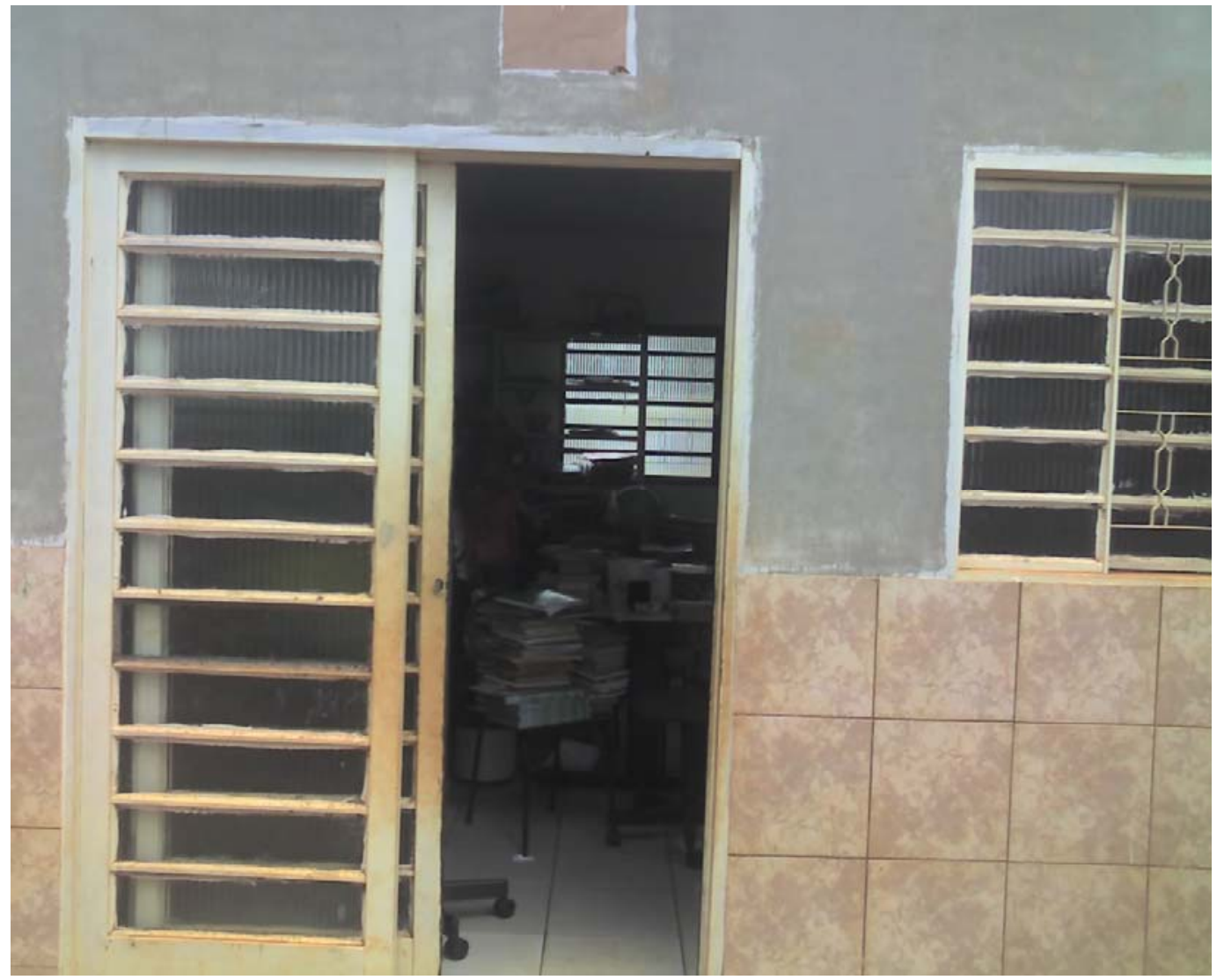

Figura 23 - Entrada da Biblioteca

Após o levantamento dos mobiliários e equipamentos da Biblioteca e seu depósito, pela Frente de Leitura - Sonhar Acordado, obteve-se o total de: 12 cadeiras cinzas; duas (2) cadeiras giratórias; três (3) cadeiras vermelhas; quatro (4) mesas brancas; 16 estantes cinzas com canto; 10 estantes brancas; um (1) computador (doado pelos voluntários do Sonhar Acordado); duas estantes sem canto; um mostruário de Gibi; pasta de arquivo; pasta suspensa; fitas VHS; revistas; livros; brinquedos e jogos. 
O acervo da Biblioteca é composto por livros didáticos, literatura brasileira, material de referência (enciclopédias e dicionários) e gibis, que atende às 50 crianças e adolescentes da instituição, seu público alvo. O material é disposto nas estantes, praticamente, separados em acervo geral, gibiteca e publicações de referência, esses materiais nunca foram processados. Tais documentos são selecionados, de acordo com a pertinência e conservação do material, por bibliotecárias que também são voluntárias da Frente de Leitura do Sonhar Acordado, equipe responsável pela revitalização da biblioteca, conforme Figura 24.

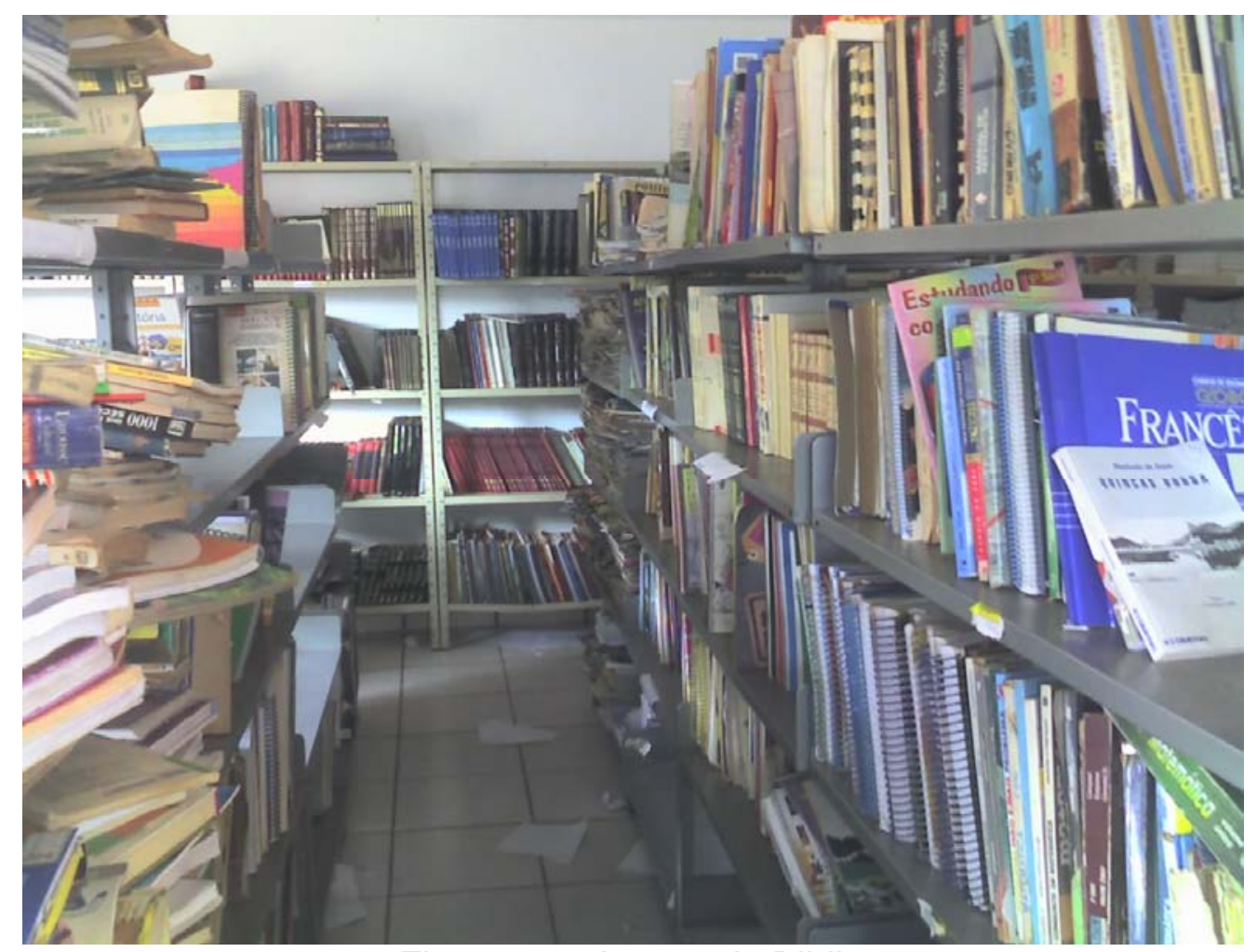

Figura 24 - Acervo da Biblioteca

\subsubsection{Relação das Crianças e Adolescentes com a Biblioteca}

As crianças e adolescentes gostam da Biblioteca da instituição, o que é possível constatar tanto no questionário quanto no fato delas usarem a Biblioteca mesmo com o seu acervo desorganizado e demonstrarem aos voluntários da Frente de Leitura interesse nos livros, além de pedir-lhes sugestões de leitura. 
O orfanato não tem uma sala separada para as crianças brincarem ou jogarem, exceto a varanda onde também são realizadas as refeições, com isso algumas crianças utilizam o espaço da Biblioteca para brincarem e/ou jogarem. A Hora do Conto muitas vezes é realizada na Biblioteca, o que é um indicador positivo, no que tange ao desenvolvimento das crianças, pois os seus questionamentos podem ser vistos como uma forma de adquirirem informações que estão fora da sua formação cognitiva e provavelmente podem vir a se transformar em conhecimento. Aumentando os laços lúdicos entre o Centro Cultural e as crianças.

\subsubsection{Perfil dos usuários da Biblioteca Lar Rita de Cássia}

Por meio da análise dos resultados obtidos após a aplicação dos questionários (Anexo C), com crianças e adolescentes de até 18 anos do Orfanato Lar Rita de Cássia foi possível analisar o perfil dos usuários. Os questionários foram aplicados em uma amostra de 22 internos entre 0 a 18 anos. As crianças e adolescentes respondentes, não foram selecionadas, mas responderam de forma aleatória entre os internos presentes no orfanato naquele dia.

As Questões 5, 6, 12 e 6 (Anexo C) são de múltipla escolha. 


\section{Idade dos internos}

Entre os 22 internos, 50\% tinham até 11 anos e os outros 50\% de 12 a 18 anos. Conforme demonstra a Figura 25. A amostra confirma os dados aqui levantados, com fidedignidade, pois a biblioteca atende desde o público infantil até público Juvenil.

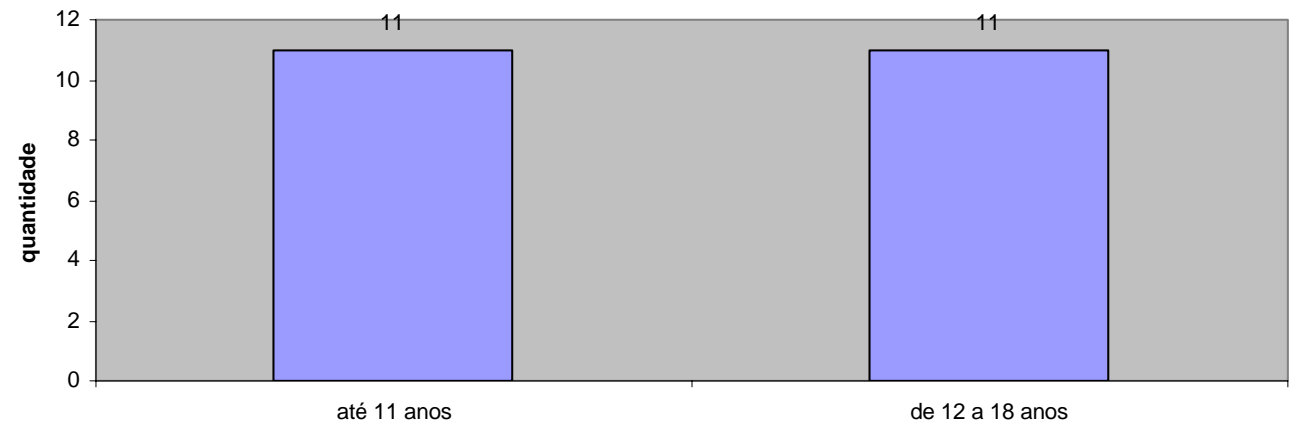

Figura 25 - Idade dos internos

\section{Sexo}

A amostra indicou um equilíbrio entre crianças e adolescentes de sexo masculino (55\%) e as do sexo feminino (45\%), conforme Figura 26:

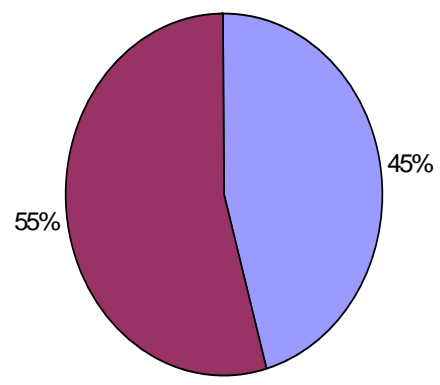

Figura 26 - Sexo 


\section{Escolaridade}

Constata-se que a maioria das crianças e jovens do orfanato $(86,4 \%)$ está cursando o ensino fundamental, e os demais (13,6\%) cursam o ensino médio, de acordo com a Figura 27:

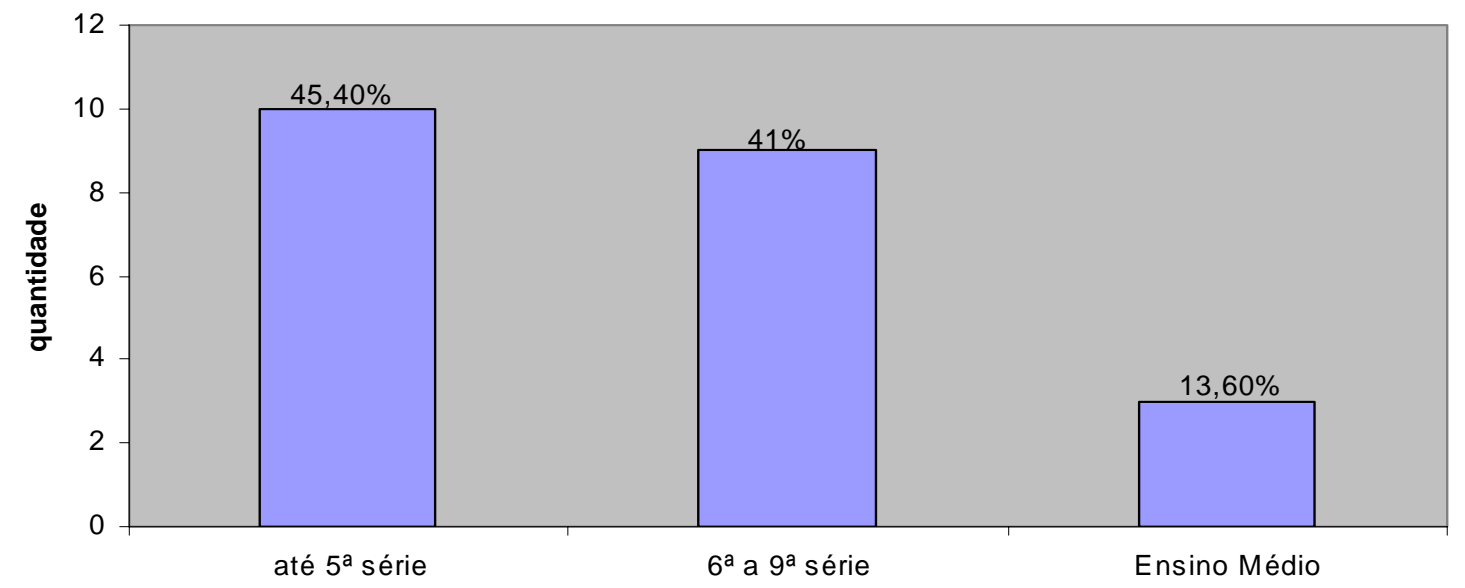

Figura 27 - Escolaridade

\section{Interesse pela leitura}

Quanto a relação da criança com a leitura, conforme Figura 28, 47,6\% das crianças e adolescentes demonstram gostar ou gostar muito de ler, enquanto a minoria $(4,8 \%)$ demonstra não gostar de ler.

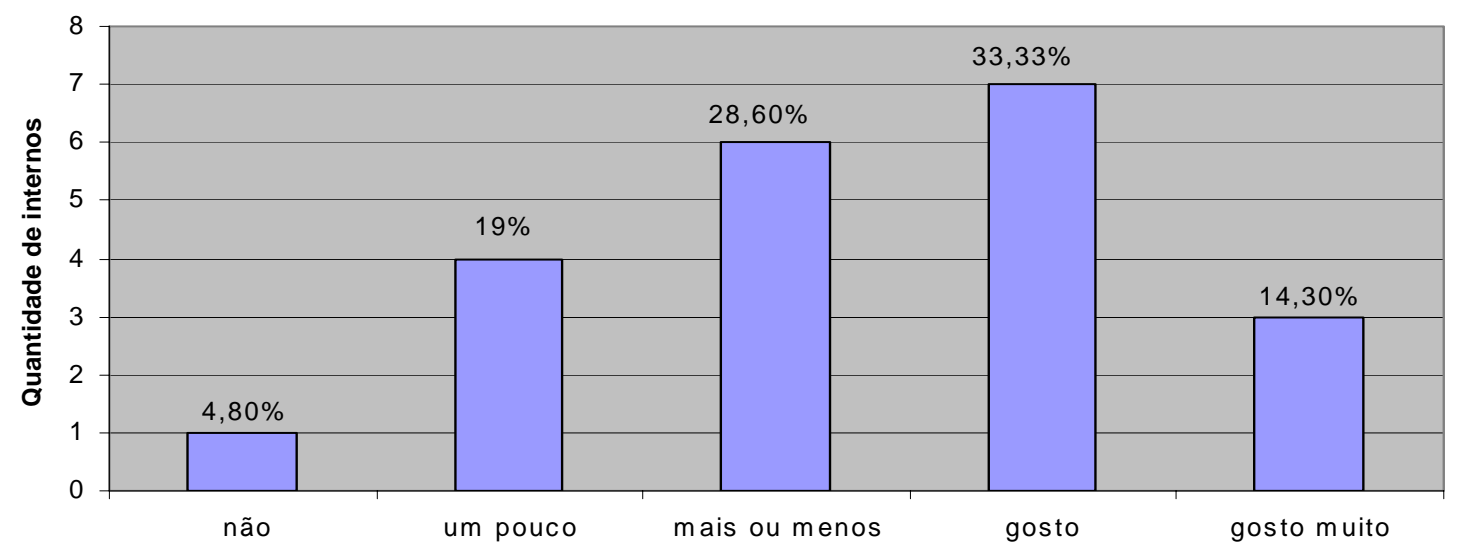

Figura 28 - Interesse pela leitura 


\section{Preferência em ler}

Constata-se, conforme Figura 29, que os internos do Orfanato Lar Rita de Cássia mostram ter preferência em ler Gibi (50\% dos usuários), romance (31,8\% dos usuários) e poucos se interessam por jornais (13,6\% dos usuários), revistas informativas (18,1\% dos usuários) e de ficção (18,1\% dos usuários), ressaltando que o usuário pode ter preferência por mais de um tipo de leitura.

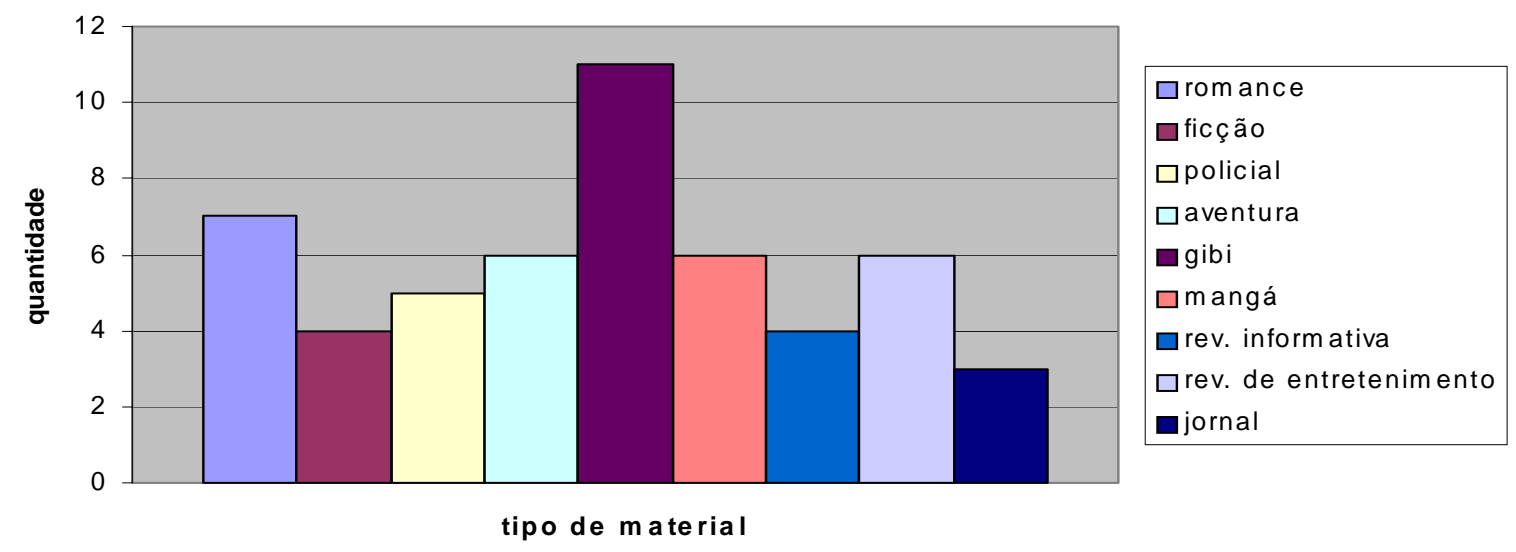

Figura 29 - Preferência em ler

\section{Tipo de material de leitura}

De acordo com a Figura 30, as crianças e adolescentes lêem com mais freqüência os livros escolares (63,6\% dos usuários) e os Gibis (50\% dos usuários), sendo que podem ler com maior freqüência mais de um tipo de obra.

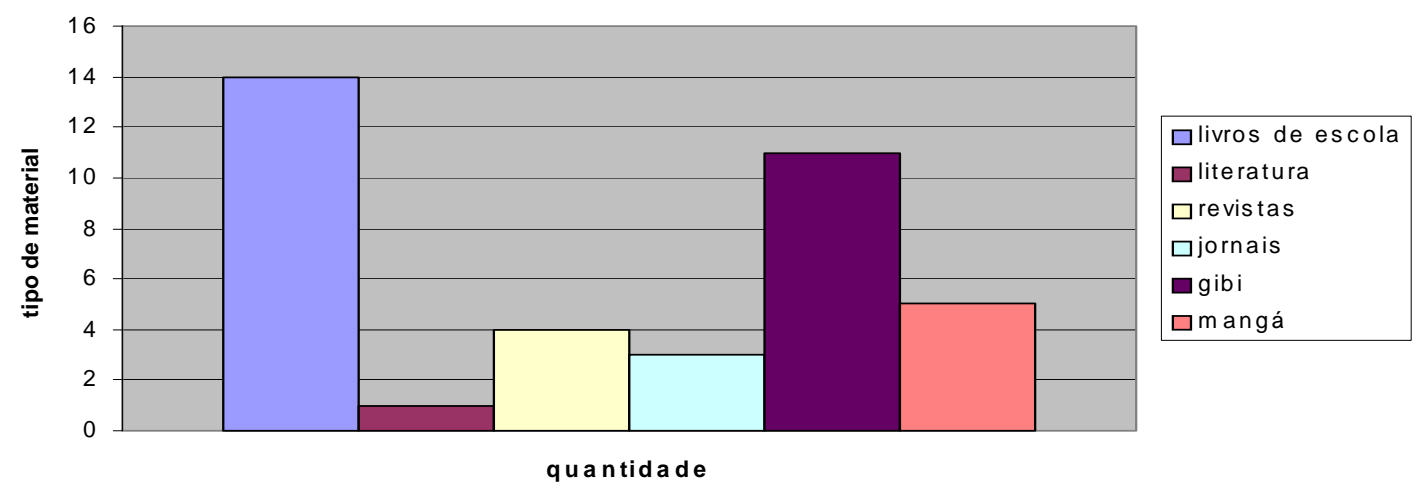

Figura 30 - Tipo de material de leitura 


\section{Quantidade de livros lidos por ano}

O grupo de usuários foi dividido em dois subgrupos, para se conhecer as diferenças de hábitos de leitura entre os internos de até 11 anos e os de 12 a 18 anos, ficando com a seguinte composição: 10 crianças possuem até 11 anos e 11 adolescentes estão entre 12 a 18 anos que perfazem o total de 21 internos, sendo que uma criança não pôde responder, pois ainda não sabia ler.

Observa-se, conforme Figura 31, que entre as crianças de até 11 anos que responderam a essa pergunta $60 \%$ não leram nenhum livro, além dos obrigados pela escola.

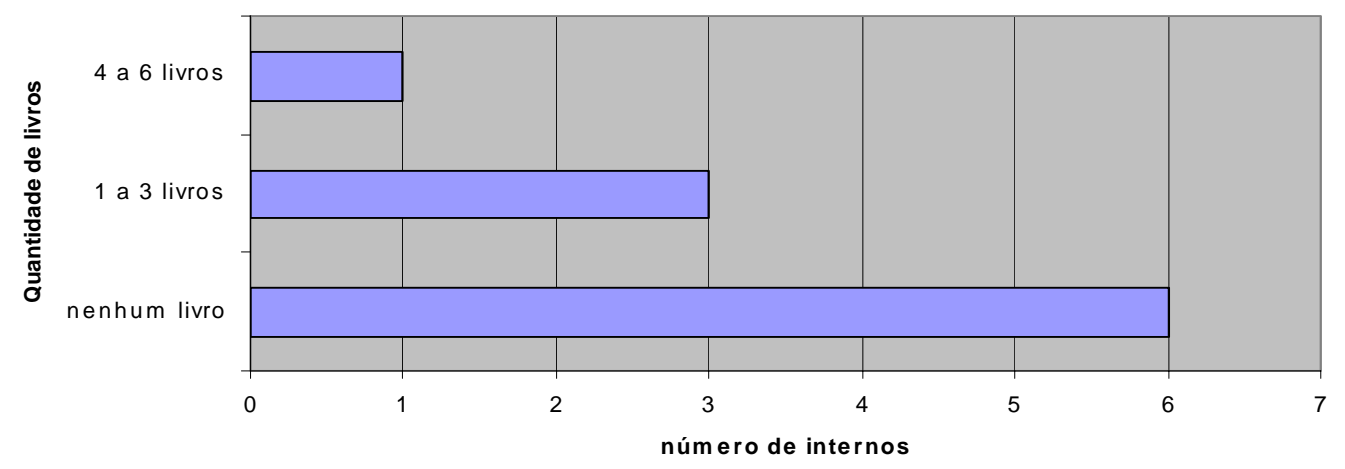

Figura 31 - Quantidade de livros lidos por crianças de até 11 anos

Quanto aos internos na faixa de 12 a 18 anos, 9\% não leram nenhum livro. Como a pergunta foi aberta três adolescentes optaram por não responder numericamente e escreveram: "não sei"; "não faço idéia de quantos livros li" e "li muitos livros", conforme Figura 32.

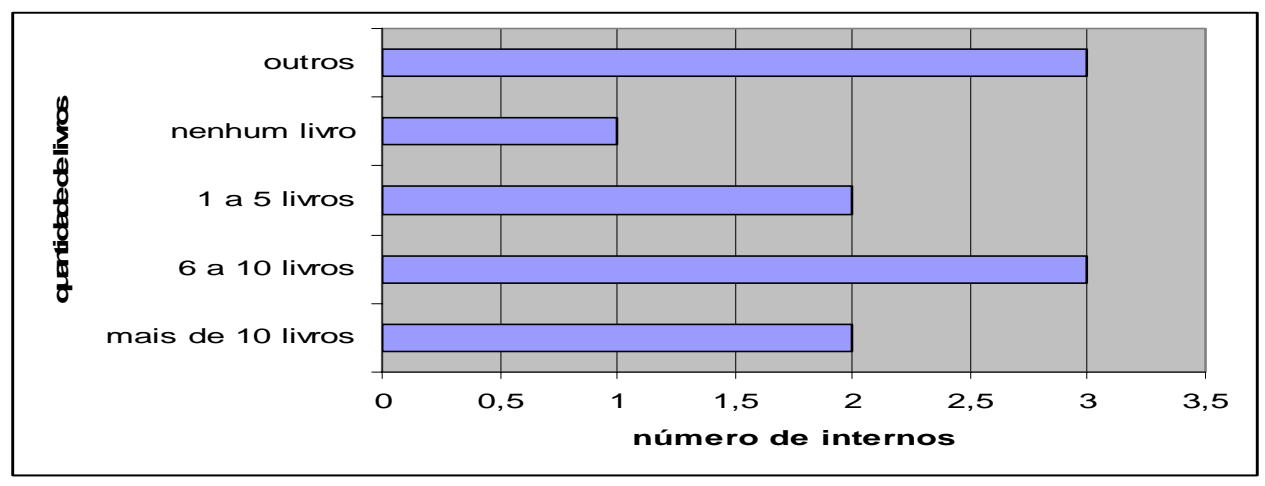

Figura 32 - quantidade de livros lidos por adolescente de 12 a 18 anos 


\section{Quantidade de livros obrigatórios lidos por ano}

Em relação a literatura obrigatória pela escola, 40\% dos usuários de até 11 anos, afirmaram que leram entre 1 a 3 livros por ano, bem como afirmam ter lido de 4 a 6 livros, e 20\% das crianças de até 11 anos não leram nenhum livro, conforme Figura 33.

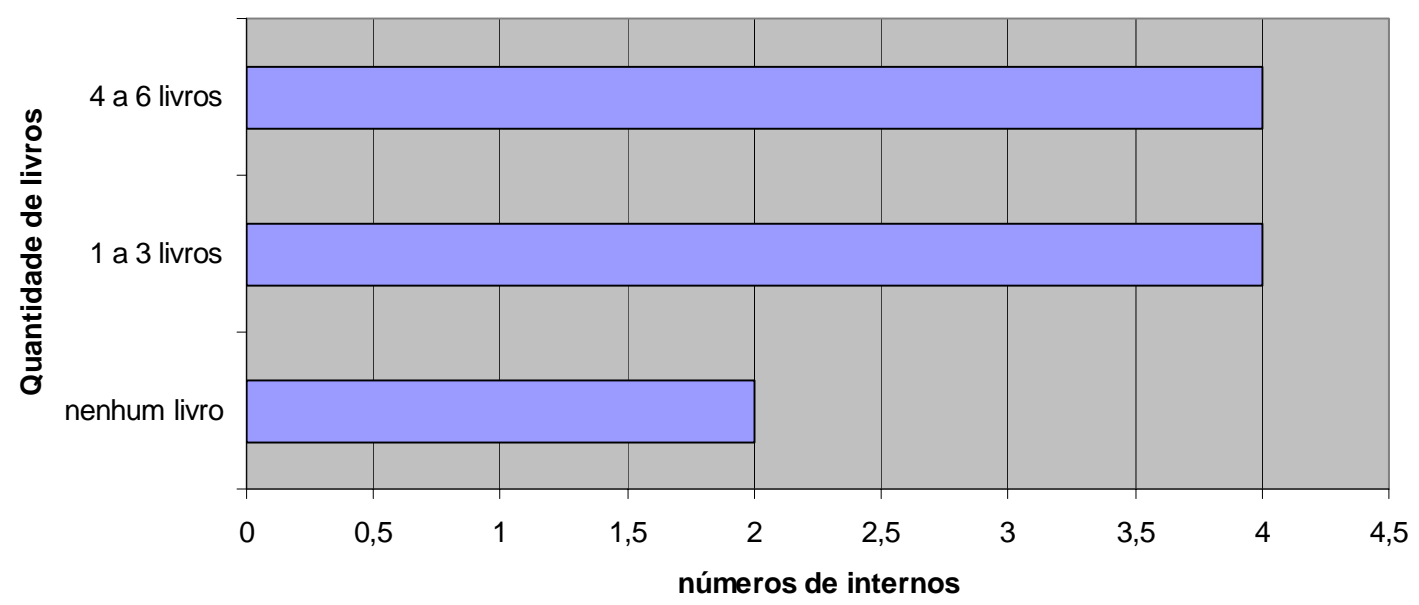

Figura 33 - Quantidade de livro lidos por crianças de até 11 anos, obrigados pela escola

Na faixa etária de 12 a 18 anos, conforme Figura 34, 27,27\% não leu nenhum livro obrigado pela escola. Enquanto 27,27\% leram entre 1 a 5 livros, 27,27\% de 6 a 10 livros e os outros $18,18 \%$ leram mais de 10 livros indicados pela escola.

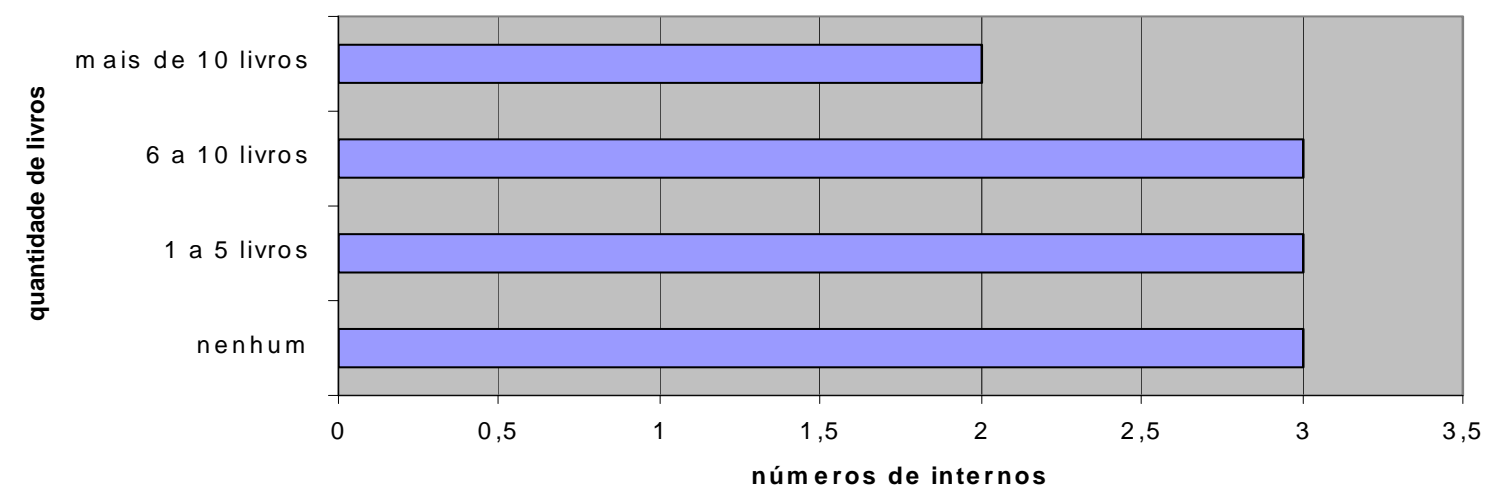

Figura 34 - Quantidade de livro lidos por crianças de 12-18 anos, obrigados pela escola 


\section{Biblioteca escolar}

Quanto a existência de biblioteca nas escolas dos internos, 75\% afirmaram que em suas escolas tem biblioteca, 10\% não sabiam informar e 15\% dos usuários não tem biblioteca em suas escolas, conforme Figura 35.

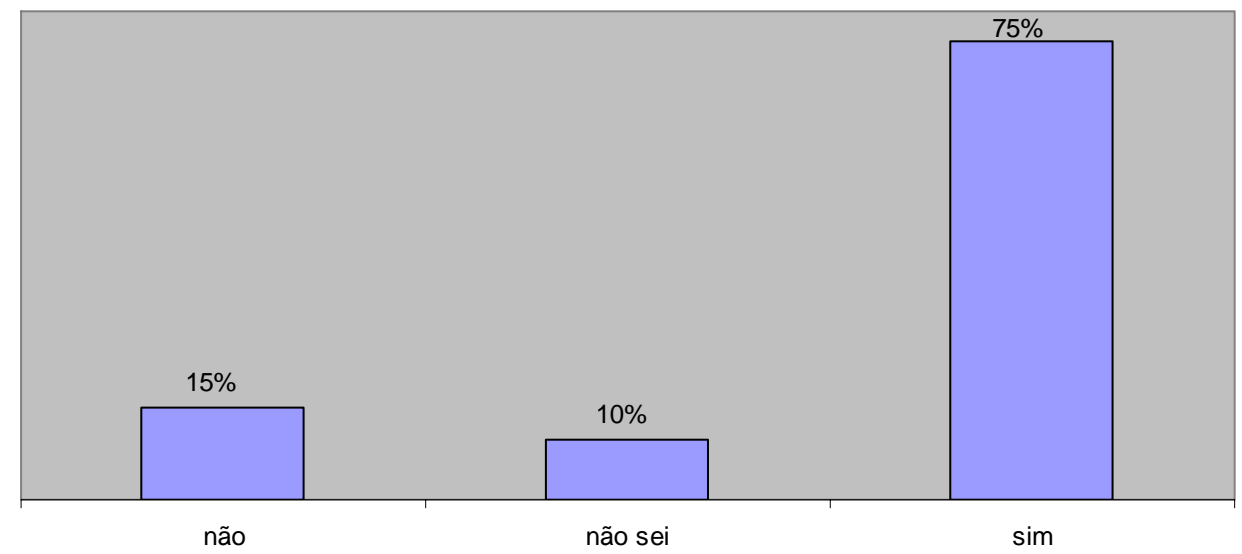

Figura 35 - Biblioteca escolar

\section{Usabilidade da Biblioteca escolar}

Conforme Figura 36, dos 15 usuários que responderam haver biblioteca em suas escolas apenas dois (13\%) não a usam.

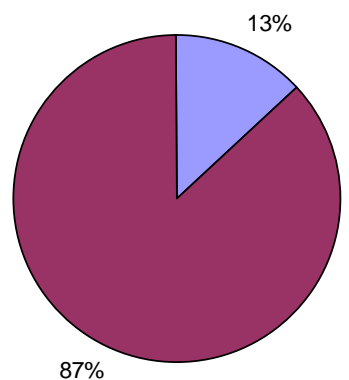

$$
\begin{aligned}
& \square \text { não } \\
& \square \operatorname{sim}
\end{aligned}
$$

Figura 36- Uso da biblioteca escolar 


\section{Biblioteca do Orfanato Lar Rita de Cássia}

A Biblioteca do Orfanato Lar Rita de Cássia é usada por 73\% dos internos, conforme figura 37:

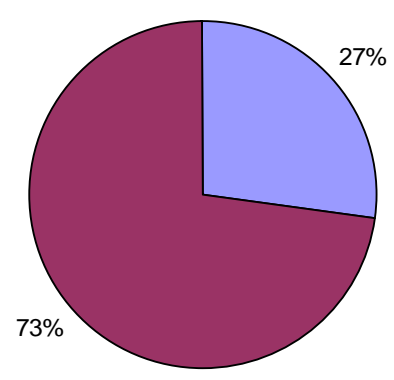

Figura 37 - Biblioteca do Orfanato Lar Rita de Cássia

\section{Atividades da Biblioteca do Orfanato}

Notou-se que as crianças e adolescentes costumam usá-la especialmente para estudar (40\%), conforme Figura 38, e 41,5\% usam como empréstimo ou para ler livros e gibis, $14 \%$ a utilizam para fazer alguma pesquisa, e 4,5\% afirmam que vão a Biblioteca para "ler alguma revista e passar o tempo".

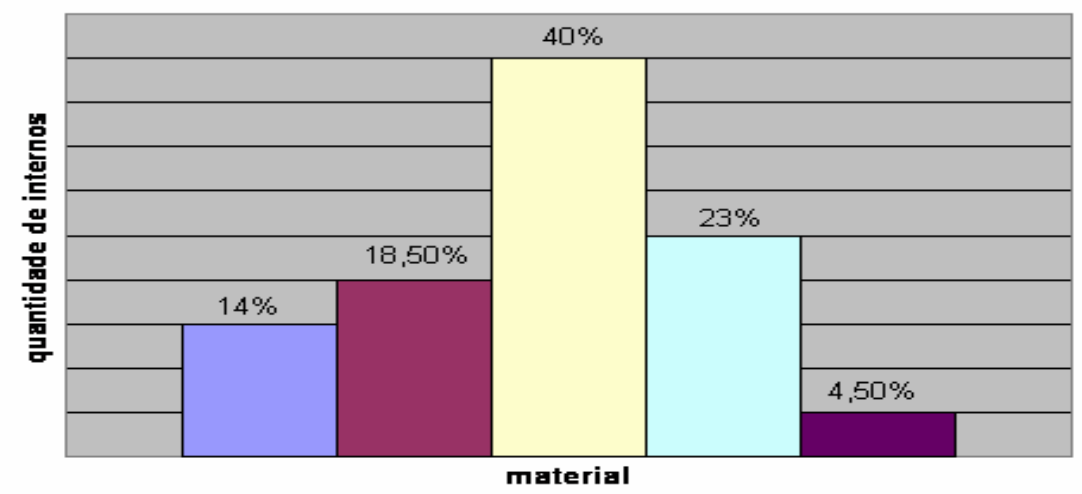

Figura 38 - Atividades principais 


\section{Usuários que não usam a Biblioteca}

Dentre os 13\% dos usuários que não usam a Biblioteca do Orfanato Lar Rita de Cássia, conforme Figura 38, 16,6\% destes admitiram não usar a Biblioteca por não haver interesse: 16,6\% não a utilizam por nunca ter precisado e a grande maioria $(66,6 \%)$ por não conhecer o que tem na biblioteca, conforme Figura 39.

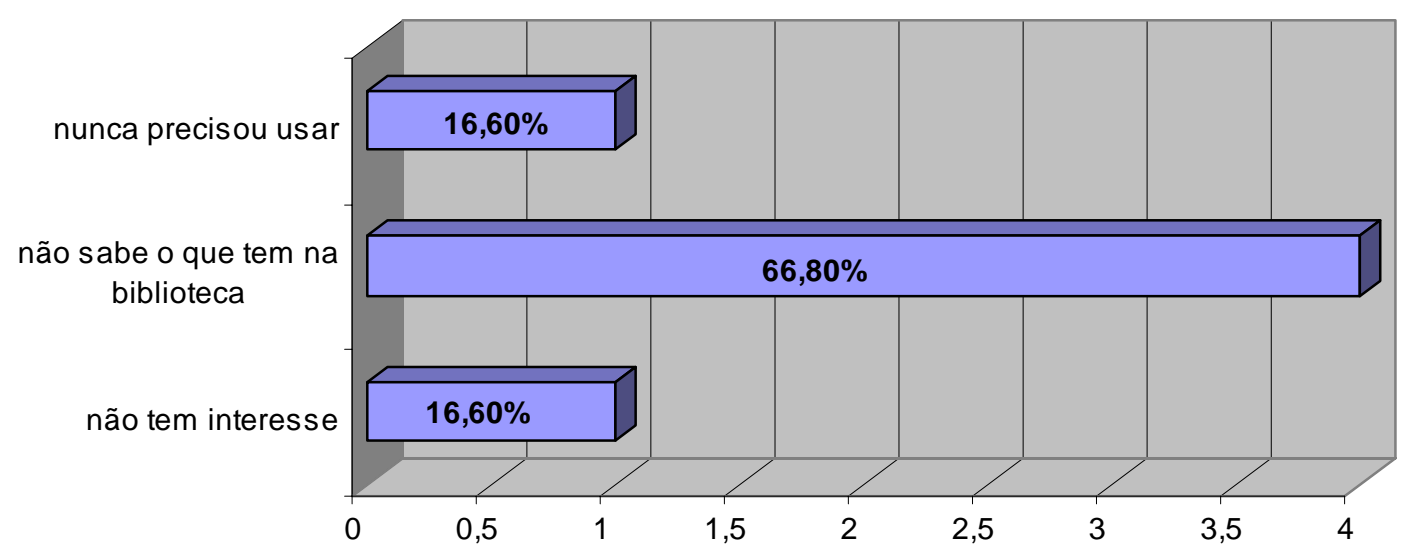

Figura 39 - Motivo de não utilizar

\section{Internet}

A maioria dos internos (63\%) do Orfanato Lar Rita de Cássia nunca tiveram acesso à Internet, de acordo com Figura 40:

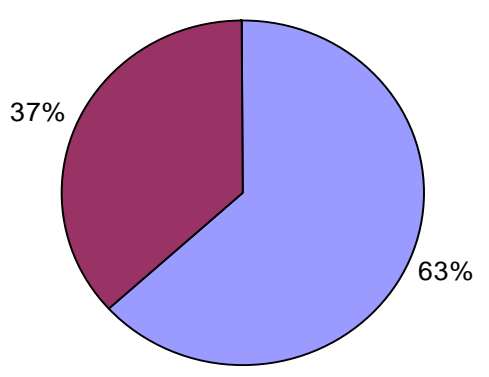

Figura 40 - Acesso à Internet 


\section{Interesse em usar a Internet}

Dos $63 \%$ que nunca usufruíram dos benefícios da Internet, todos tem interesse em usá-la. Conforme Figura 41.

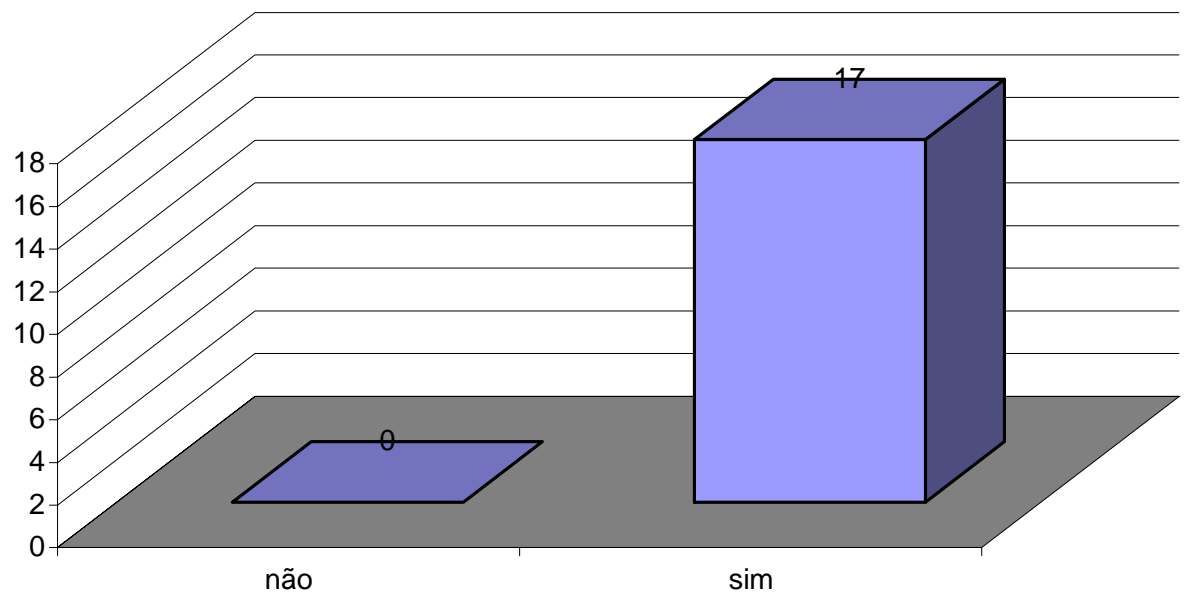

Figura 41 - interesse em usar a Internet

\section{Sites de Interesse}

Os internos, que já tiveram acesso à Internet e os que só ouviram falar demonstram interesse em usá-la especialmente para jogar (59\%) e visitar sites de relacionamento (50\%) e demonstraram menos interesse em ver charges $(22,7 \%)$ e conversas em chats $(22,7 \%)$. Conforme Figura 42 :

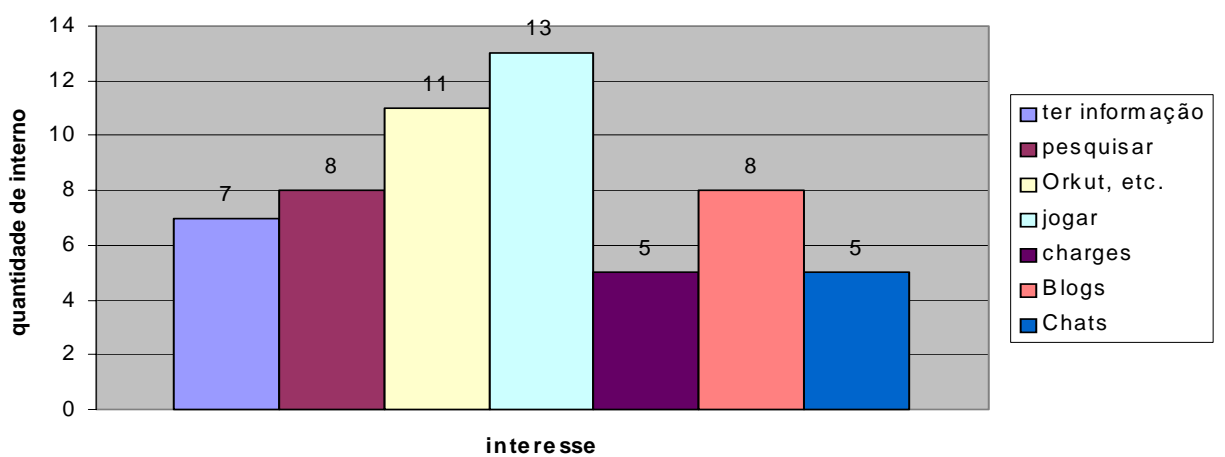

Figura 42 - Interesse na Internet 


\section{PROPOSTA PARA IMPLANTAÇÃO DE UMA BIBLIOTECA NO ORFANATO LAR RITA DE CÁSSIA}

\subsection{INTRODUÇÃO}

No Orfanato Lar Rita de Cássia, observou-se a necessidade de implantar uma biblioteca que atendesse as demandas educacionais, culturais e sociais das crianças e adolescentes. Criar um ambiente lúdico e interativo para as crianças menores, a fim de despertar o amor ao livro, desenvolver sua capacidade de criatividade e torná-la capaz de lidar com a realidade. Para as crianças maiores e adolescentes, a biblioteca será um referencial para suas pesquisas e trabalhos escolares, realizar atividades contínuas de incentivo a leitura, desenvolver valores e capacitá-los a lidar com seus conflitos interiores.

No Orfanato Lar Rita de Cássia, existe um espaço mobiliado onde estão os livros; sejam eles: didáticos, material de referência, gibis e brinquedos doados, bem como um computador ainda não utilizado. O acervo não foi tratado nem processado, tendo sido feito somente por um processo de pré-seleção. Este espaço serve como um ambiente de estudo e onde os internos do Orfanato podem retirar livros e gibis.

Após análise do perfil do usuário constatou-se que $86,4 \%$ cursam o ensino fundamental e 13,6\% o ensino médio, enfatizando a necessidade da biblioteca atuar como apoio ao processo ensino-aprendizagem.

A maioria das crianças e adolescentes demonstram interesse em ler, apesar de lerem em maior quantidade gibis, por ser uma leitura mais rápida e de fácil entendimento, deixando a literatura em um plano secundário. A pesquisa apresentou que a maioria das crianças e adolescentes lêem de 0 a 3 livros por ano, não obrigatórios pela escola. Isso significa que os internos necessitam de atividades de incentivo a leitura. Quanto às leituras obrigatórias pela escola, as crianças menores lêem em menor quantidade do que as crianças maiores, apesar de demonstrarem maior interesse em ler. 
O Orfanato Lar Rita de Cássia possui uma sala com computadores, cabos, impressoras, mesas e cadeiras doados, porém não são utilizados, pois não possui pessoal ou condições para instalar e fazer a manutenção dos equipamentos, enquanto isso a maioria das crianças e adolescentes nunca tiveram contato com o computador, muito menos acesso a Internet, apesar de demonstrarem interesse.

Concluiu-se pelo estudo de caso a necessidade de apresentar uma proposta de implantação da biblioteca do Orfanato Lar Rita de Cássia que atenda as crianças e adolescentes do orfanato e ofereça serviços focados tanto no processo ensinoaprendizagem como no incentivo a leitura, apoiados nas atividades biblioterapêuticas e de lazer.

Esta proposta deve ser ponto de partida para a elaboração do projeto executivo. O projeto deverá ser executado em módulos, que poderão ser realizados ao mesmo tempo o cada um no tempo mais apropriado ao seu desenvolvimento, de acordo com a Tabela 16: 
Tabela 16 - Elaboração do Projeto

\begin{tabular}{|c|c|c|c|}
\hline Número da & Fases & Etapas & Atividades \\
\hline \multirow{3}{*}{1} & \multirow[t]{3}{*}{ Técnica } & Coleta & $\begin{array}{ll}\text { - } & \text { Seleção } \\
\text { - } & \text { Aquisição } \\
\text { - } & \text { Doação/Intercâmbio }\end{array}$ \\
\hline & & $\begin{array}{l}\text { Processos } \\
\text { Técnicos }\end{array}$ & $\begin{array}{l}\text { - Catalogação } \\
\text { - } \text { Classificação } \\
\text { - Armazenagem }\end{array}$ \\
\hline & & Disseminação & $\begin{array}{ll}\text { - } & \text { Recuperação } \\
\text { - } & \text { Empréstimo } \\
\text { - } & \text { Referência } \\
\text { - } & \text { Palestras e exposições } \\
\text { - } & \text { Atividades infanto-juvenis } \\
\text { - } & \text { Atividades biblioterapêuticas } \\
\end{array}$ \\
\hline 2 & Tecnológica & $\begin{array}{l}\text { Biblioteca } \\
\text { Laboratório } \\
\text { Redes de } \\
\text { comunicação }\end{array}$ & $\begin{array}{l}\text { - Software } \\
\text { - Hardwares }\end{array}$ \\
\hline 3 & $\begin{array}{c}\text { Instalações } \\
\text { Físicas }\end{array}$ & $\begin{array}{l}\text { Espaço Físico } \\
\text { Mobiliário }\end{array}$ & $\begin{array}{ll}\text { - } & \text { Ambientes } \\
\text { - Infantil e infanto-juvenil } \\
\text { - } & \text { Atividades técnicas } \\
\text { - } & \text { Atividades de usuário }\end{array}$ \\
\hline
\end{tabular}

É importante reforçar que esta Biblioteca será constituída de duas "Bibliotecas", com características diferenciadas e específicas, e, portanto, cada módulo deverá ser estruturado, abrangendo as duas seções da Biblioteca: biblioteca infantil e biblioteca escolar. 


\subsection{OBJETIVOS}

\subsubsection{Objetivo Geral}

Proporcionar às crianças e adolescentes do Orfanato Lar Rita de Cássia um ambiente informacional capaz de promover o desenvolvimento social, pessoal e educacional.

\subsubsection{Objetivos Específicos}

-Disponibilizar um acervo compatível com as necessidades do grupo;

- Conscientizar os usuários sobre a importância de utilizar e conservar o acervo;

-Estimular a criação do hábito de leitura, voltando tanto ao crescimento intelectual como ao entretenimento;

- Criar uma brinquedoteca;

-Estruturar um laboratório de informática na instituição, possibilitando a inclusão digital das crianças e adolescentes do Orfanato;

- Implantar a automatização do acervo, possibilitando um maior controle e organização para a recuperação de informação;

-Proporcionar serviço de caráter biblioterapêutico, visando a melhoria de vida dos internos;

-Apoiar o processo de ensino-aprendizagem dos usuários por intermédio da pesquisa e outras atividades de acesso à informação;

-Promover uma melhoria da qualidade de vida dos internos integrando-os ao mundo da informação. 


\subsection{METODOLOGIA}

O planejamento e estruturação do projeto serão de responsabilidade de uma equipe de bibliotecários da ONG Sonhar Acordado que atuarão na organização da Biblioteca, no incentivo à leitura, no apoio ao processo ensino-aprendizagem e na aplicação de técnicas biblioterapêuticas, contando, em algumas dessas atividades, com outros voluntários formados em áreas afins a essas atividades, como bibliotecário, professor, terapeuta, psicólogo, sociólogos, artistas, e outros. 


\subsection{SUGESTÕES PARA A IMPLANTAÇÃO DA BIBLIOTECA DO ORFANATO LAR RITA DE CÁSSIA}

A Biblioteca deverá atender às demandas dos usuários, inclusive com relação ao horário. Como nem sempre terá um bibliotecário para cuidar da biblioteca enquanto os usuários utilizam, todos serão orientados a consultar o acervo de forma a preservá-lo. As crianças maiores serão responsáveis por deixar a biblioteca sempre em ordem.

\section{Usuários}

A biblioteca deverá atender, prioritariamente, as crianças e adolescentes do Orfanato Lar Rita de Cássia, bem como aos dirigentes e funcionários que dela necessitarem.

\section{Instalação}

O espaço físico da Biblioteca deverá ser acrescido do que atualmente é o depósito, local onde são guardados livros e brinquedos da biblioteca e está ao lado da mesma. Este depósito será o espaço utilizado para a brinquedoteca, local em que as atividades lúdicas serão implantadas, como por exemplo, hora do conto, teatrinho, brincadeiras diversas.

A Biblioteca deverá ter um espaço para o acervo com, três mesas para estudo, uma mesa para o bibliotecário, um computador para a automação do acervo, e um para a consulta ao acervo.

O ideal seria que o laboratório de informática ficasse junto à biblioteca, mas nesse momento inicial ele deverá permanecer onde se encontra. Os voluntários da ONG Sonhar Acordado, capacitados na área de ciências da computação, deverão fazer a sua instalação e dar manutenção aos computadores já existentes. Serão necessários cabos, modem para acesso a internet e outros materiais para serem planejado e estruturado corretamente. 


\section{Processamento Técnico}

Deverá ser estabelecida uma política de seleção do material bibliográfico de acordo com a edição, pertinência do assunto, usabilidade do material, conservação e demanda e a realização periódica de estudo de usuário. A aquisição será realizada por intermédio de doação e intercâmbio.

Quanto à catalogação dos materiais bibliográficos deverá ser adotada a AACR2. Sugere-se a utilização do software Winlsis, pois é um software livre de fácil instalação e manuseio, ou do Acess que é um software bastante difundido, porém este poderá ser substituído de acordo com o interesse das bibliotecárias voluntárias da ONG Sonhar Acordado.

A classificação utilizada poderá ser a Classificação Decimal Universal (CDU) simplificada.

As normas básicas para a organização serão: AACR2, CDU e as Normas técnicas da ABNT (NBR).

\section{Serviços oferecidos}

O bibliotecário e os voluntários deverão auxiliar as crianças e adolescentes em pesquisas e trabalhos escolares.

A Biblioteca deverá ter uma programação semanal de atividades variadas, acompanhadas por bibliotecários e outros profissionais, como:

Hora do conto: momento em que conta-se história de forma criativa podendo usar bonecos e marionetes, entre outros no auxílio da atividade.

Teatrinho: apresentação de peças teatrais que visam tanto o entretenimento como a criação de valores. As crianças também podem fazer partes das peças.

Leituras biblioterapêuticas: tipo de leitura que pode ser realizada de diversas formas de acordo com a demanda do usuário.

Lista de sugestão de leitura: é uma lista onde estarão citados diversos tipos de leitura, em especial, escapista e informativa. 
Gincana do livro: haverá uma lista de livros e os participantes da gincana que serão no mínimo dois grupos onde os componentes de cada grupo deverão ler o livro escolhido para o grupo. Ao final, o grupo deverá realizar uma atividade para apresentar o livro bem como sua história e seus pontos principais a outro grupo. Essa gincana será supervisiona pelo bibliotecário.

Roda de histórias: é a atividade em que a criança conta uma história para as outras exercendo sua criatividade.

Brincadeiras, pinturas de histórias, jogos e vídeos, e outras.

\section{Recursos Necessários:}

\section{Recursos humanos}

A princípio a Biblioteca conta com o apoio de quatro Bibliotecárias e voluntárias da ONG Sonhar Acordado, como a Biblioteca não tem recursos humanos, por isso será importante um rodízio entre os voluntários bibliotecários para realizarem as atividades referentes a sua organização, bem como para treinar internos maiores para as atividades operacionais de atendimento, empréstimo e outras, compatíveis com de um auxiliar de biblioteca. Estes internos maiores (17 anos adiante) poderiam ter incentivos, como a de um curso de auxiliar de biblioteca, encaminhando-os para um trabalho futuro.

\section{Recursos Informacionais}

Livros didáticos, literatura diversa, materiais de referência, brinquedos, multimeios, gibis, mangás e revistas.

\section{Recursos Materiais}

Os recursos materiais iniciais serão os existentes na própria Biblioteca:

a) Mobiliário (mesa, cadeira, estante) 
b) Material documental selecionado pela equipe de bibliotecários;

c) Equipamentos para atividade de lazer (jogos de raciocínio, cantinho da leitura, brinquedos, fantasias);

d) Computador.

Sugere-se pufs e tapetes coloridos para tornar o ambiente mais alegre e divertido para a brinquedoteca.

\section{Recursos Financeiros}

As doações são o único meio de obter material bibliográfico e equipamentos para a biblioteca e para o laboratório de informática, neste primeiro momento. Podem ser promovidos eventos, com resultados que possam ser direcionados para a biblioteca e o laboratório de informática, como já é uma prática nessa ONG.

\section{Avaliação}

A avaliação dos serviços oferecidos pela biblioteca poderá ocorrer por meio de: relatórios de atividades, consulta ao usuário, caixa de sugestões e críticas e em especial pela relação que a criança e o adolescente passará a ter com a biblioteca.

\section{Motivação a comunidade}

Uma forma de motivar a comunidade a se relacionar com a Biblioteca poderá ser estabelecida, por exemplo, na abertura da Biblioteca com a realização de um evento de inauguração, com o comparecimento da comunidade, podendo ser a semente de um centro cultural do Orfanato Lar Rita de Cássia. 


\section{CONCLUSÃO}

O Orfanato Lar Rita de Cássia é uma instituição filantrópica que abriga crianças e adolescentes que sofreram alguma agressão dos pais, a instituição também exerce trabalho de creche atendendo crianças da comunidade. Apesar de receberem todos os cuidados materiais necessários, as crianças e adolescentes devem ter acesso a informação e utilizar os serviços de uma biblioteca com fins de inclusão social e digital, para terem suas necessidades informacionais atendidas.

A biblioteca tem como objetivo oferecer serviços que atendam as necessidades informacionais de seus usuários, recuperando informações relevantes e acessíveis. Se bem planejada, a biblioteca deve atingir seus objetivos, tornando-se uma organização dinâmica e auto-suficiente que permita atingir resultados e diminuir suas dificuldades com eficiência, eficácia e efetividade. A Biblioteca do Orfanato Lar Rita de Cássia deve ter um caráter infanto-juvenil escolar, ser capaz de atingir os requisitos anteriores e oferecer serviços de incentivo à leitura, de auxílio no processo ensino-aprendizagem, permitir a inclusão digital e ser um espaço lúdico e de entretenimento.

As crianças do Orfanato Lar Rita de Cássia necessitam de atividades lúdicas e de incentivo a leitura, e a biblioteca deve ser um ambiente prazeroso. Essas crianças gostam de ler, mas necessitam de uma orientação para escolha do material, seja ele gibis, revistas ou livros, de acordo com seu desenvolvimento, tornando-os leitores em potencial, que encontrem nos livros o prazer e formas de se tornarem pessoas melhores e mais preparadas para o futuro.

Os adolescentes, por sua vez, necessitam de incentivo para adquirir o hábito de utilizar a biblioteca numa relação mais intima com o ambiente informacional. Como não há incentivo, os adolescentes não se interessam em utilizar a biblioteca alegando não conhecê-la nem os seus serviços. Como alunos de rendimento médio precisam utilizar a biblioteca como um instrumento de apoio no processo ensino-aprendizagem, otimizando sua vida escolar.

Além das necessidades informacionais, a Biblioteca do Orfanato pode utilizar de atividades biblioterapêuticas, visto que auxiliará os internos a lidar com seus problemas, 
bom como encontrar prazer na leitura além de promover o desenvolvimento pessoal e comportamental.

O auxílio constante dos voluntários da ONG Sonhar Acordado é fundamental para que a Biblioteca possa atingir os seus objetivos, cumprir suas responsabilidades sociais e maximizar os seus resultados, preparando-os como cidadãos conscientes, competentes e capazes de enfrentar os desafios futuros. 


\section{REFERÊNCIAS}

ALMEIDA. Maria Christina Barbosa de. Planejamento de bibliotecas e serviços de informação. Brasília, DF: Briquet de Lemos/Livro, 2000. 112 p.

2. ed. rev. e ampl. Brasília, DF: Briquet de Lemos/Livros, 2005. 144

p.

ALVES, Maria Helena Hees. A aplicação da biblioterapia no processo de reintegração social. Revista Brasileira de Biblioteconomia e Documentação, v. 15, n. 1/2, p. 54-61, jan./jun. 1982.

ARRUDA, Guilhermina Melo. As práticas da biblioteca pública a partir das suas quatro funções básicas. In: CONGRESSO BRASILEIRO DE BIBLIOTECONOMIA E DOCUMENTAÇÃO, 19., 2000, Porto Alegre. Anais... Porto Alegre: Associação Rio Grandense de Bibliotecários, 2000.

ASSOCIAÇÃO BRASILEIRA DE NORMAS TÉCNICAS. NBR 6023: informação e documentação: referência: elaboração, 2002.

Janeiro, 2003.

NBR 6028: informação e documentação: resumo: apresentação. Rio de

NBR 14724: informação e documentação: trabalhos acadêmicos:

apresentação. Rio de Janeiro, 2006.

NBR 10520: informação e documentação: citações em documentos:

apresentação. Rio de Janeiro, 2002.

BAMBERGER, Richard. Como incentivar o hábito da leitura. 6. ed. São Paulo: Ática, 1995. (Série Educação em Ação).

BAPTISTA, Mirian Veras. Planejamento: Introdução a metodologia do planejamento social. 4. ed. São Paulo: Moraes, 1981. 109 p. 
BAPTISTA, Sofia Galvão; CUNHA, Murilo Basto da. Estudos de usuários: visão global dos métodos de coleta de dados. Perspectivas em ciências da Informação, v. 12, n. 2, p. 168-184, maio/ago. 2007.

BARRETO, Auta Rojas, et al. Gestão de unidades de informação: manual. Curitiba: Instituto de Tecnologia do Paraná, 1997. 259 p.

BORBA, Maria do Socorro de Azevedo; BORBA, Andreza Cristina de Azevedo.

Biblioteca escolar: como dinamizá-la através de ações culturais? In: CONGRESSO BRASILEIRO DE BIBLIOTECONOMIA, DOCUMENTAÇÃO E CIÊNCIA DA INFORMAÇÃO, 22., 2007, Brasília, DF. Anais... Brasília, DF: FEBAB, 2007. 1 CD-ROM.

BORDENAVE, Juan Díaz; PEREIRA, Adair Martins. Estratégicas de ensinoaprendizagem. 21.ed. Petrópolis: Vozes, 2000.

BORGES, Maria Alice de Guimarães. Conceito de planejamento estratégico.Brasília, DF: UnB. Aula apresentada em 2/2006 na disciplina Planejamento de Sistema de Informação.

BELKIN, N. J. Information concepts for information science. Journal of Documentation, v. 34, n. 1, p. 55-85, Mar. 1978.

BUENO, S. B.; CALDIN, C. F. A aplicação da biblioterapia em crianças enfermas. Rev. ACB: Biblioteconomia em Santa Catarina, v. 7, n. 1, p. 157-170, 2002.

BUENO, S. B.; STEINDEL, G. E. A biblioteca e brinquedoteca: mediadores do livro, objeto prazeroso de saber e lazer no ambiente escolar. Ciências \& Cognição, v. 8, p.1021, 2006.

CALAZANS, Angélica Taffano Seidel. Conceitos e uso da informação organizacional e informação estratégica. TransInformação, Campinas, v. 18, n. 1, p. 63-70, jan./abr. 2006.

CALDIN, Clarice Fortkamp. A leitura como função terapêutica: biblioterapia. Encontros Bibli: Revista Eletrônica de Biblioteconomia e Ciência da Informação, Florianópolis, n. 12, dez. 2001. Disponível em <http://www.encontros-bibli.ufsc.br>. Acesso em: 23 nov. 2007. 
CALDIN, Clarice Fortkamp. Biblioterapia: atividades de leitura desenvolvidas por acadêmicos do curso de Biblioteconomia da Universidade Federal de Santa Catarina. Biblios, v. 6, n. 21/22, ago. 2005.

CAMPELLO, Bernadete. Introdução ao controle bibliográfico. 2 ed. Brasília, DF: Briquet de Lemos/Livros, 2006.

CAMPELLO, B.S. et al. A coleção da biblioteca escolar na perspectiva dos parâmetros curriculares nacionais. Inf. Inf., Londrina, v. 6, n. 2, p. 71-88, jul./dez. 2001.

CAMPOS, Diego ; OLIVEIRA, Edgard Costa. A biblioterapia como fator de saúde, inclusão social e cidadania. In: I CONFERÊNCIA IBERO-AMERICANA DE COMUNICAÇÃO DA INFORMAÇÃO EM SAÚDE, 1., 2007, Brasília, DF. Anais... , Brasília, DF: CID/UnB, 2007.

CARLSON, R.; ARTHUR, N. Play therapy and the therapeutic use of store. Canadian Journal of Counseling, v. 33, n. 3, p. 212-226, 1999.

CARNEIRO, Liliane Bernardes. Leitura de imagens na literatura infantil: desafios e perspectivas na era da informação. 2008. 181 f. Dissertação (Mestrado em Ciência da Informação)-Universidade de Brasília, Brasília, 2008.

CARNEIRO, Liliane Bernardes. A leitura de imagens e o leitor infantil na sociedade da informação. In: CONGRESSO BRASILEIRO DE BIBLIOTECONOMIA, DOCUMENTAÇÃO E CIÊNCIA DA INFORMAÇÃO, 22., 2007, Brasília, DF. Anais... Brasília, DF: FEBAB, 2007. 1 CD-ROM.

CARVALHO, Bárbara Vasconcelos de. A Literatura infantil: visão histórica e crítica. 6. ed. São Paulo: Global, 1989.

CARVALHO, Ediane Galdino de. A informação como suporte de cidadania no orfanato x: uma proposta social. In: CONGRESSSO BRASILEIRO DE BIBLIOTECONOMIA BRASILEIRO DE BIBLIOTECOMIA E DOCUMENTAÇÃO, 19., 2000, Porto Alegre . Anais ... Porto Alegre: Associação Rio Grandense, 2000. Disponível em: <http://dici.ibict.br/archive/00000713/01/T053.pdf>. Acesso em: 10 set. 2008. 
CASHADAN, S. Como utilizar os contos de fada. In: . Os sete pecados capitais nos contos de fadas: como os contos de fadas influenciam nossas vidas. Tradução Maurette Brandt. Rio de Janeiro: Campus, 2000. p. 291-306.

CHIAVENATO, Idalberto; SAPIRO, Arão. Planejamento estratégico: fundamentos e aplicações. Rio de Janeiro: Elsevier, 2003.

CRUZ, Maria Aparecida Lopes de. Biblioterapia de desenvolvimento pessoal: um programa para adolescentes de periferia. 1995. 147 f. Dissertação (Mestrado em Biblioteconomia)-Pontifícia Universidade Católica de Campinas, Campinas, 1995.

CUNHA, M. B. Metodologia para estudo dos usuários da informação científica e tecnológica. Revista de Biblioteconomia de Brasília, Brasília, v. 10, n. 2, p. 5-19, 1982.

DRUCKER, Peter. A próxima sociedade é o managment. HSM Management, São Paulo, v.7, n. 36, jan./fev. 2003. Disponível em:<http://www.hsm.com.br/hsmmanagement/>. Acesso em: 1 set. 2008.

FERREIRA, Aurelio Buarque de Hollanda. Dicionário Aurélio básico da língua portuguesa. Rio de Janeiro: Nova Fronteira, 1995.

FERREIRA, Danielle Thiago. Biblioterapia: uma prática para o desenvolvimento pessoal. EDT, v. 4, n. 2, p. 33-47, jun. 2003.

FERREIRA, Maria do Carmo Sá Barreto. A biblioteca escolar e a atividade da hora do conto: espaço para formação de pequenos leitores. In: CONGRESSO BRASILEIRO DE BIBLIOTECONOMIA, DOCUMENTAÇÃO E CIÊNCIA DA INFORMAÇÃO, 21., 2005, Curitiba. Anais... Curitiba: FEBAB, 2005. 1 CD-ROM.

FISCHMANN, Adalberto A.; ALMEIDA, Martinho Isnard Ribeiro de. Planejamento estratégico na prática. 2 ed. São Paulo: Atlas, 1991.

FONTANELE, M. F.; PINTO, V. B. et al. A biblioterapia no tratamento do câncer infantil. Fortaleza: UFC, 1995. Projeto de pesquisa do curso de Biblioteconomia e Psicologia da UFC. 
FRAGOSO, G. M. O livro, a biblioteca e a primeira infância: trilogia do afeto. Presença Pedagógica, Belo Horizonte, v. 4, n. 22, jul./ago. 1998.

FUNDAÇÃO BIBLIOTECA NACIONAL (Brasil). A biblioteca pública: administração, organização, serviços. Rio de Janeiro: Departamento Nacional do Livro, 1995. 121 p.

FURLAN, José Davi. Como elaborar e implementar o planejamento estratégico de sistema de informação. São Paulo: Malron/McGraw, 1991.

GASCUEL, Jacqueline. Espaço para o livro: como criar, animar ou renovar uma biblioteca (um). Lisboa: Dom Quixote, 1987. 301 p.

GOMES, Annatália Meneses de Amorim; MELO, Egmar Longo Araújo de, et al. Avaliar e ser avaliado: uma experiência na elaboração de projetos de pesquisa. Revista Brasileira em Promoção da Saúde, Fortaleza, v. 18, n. 4, p. 165-170, out./dez. 2005.

GUMIEIRO, V. et al. A biblioterapia e o papel do bibliotecário. In: CONFERÊNCIA IBERA-AMERICANA DE COMUNICAÇÃO DA INFORMAÇÃO EM SAÚDE, 1., 2007, Brasília, DF. Anais...Brasília, DF: CID/UnB, 2007.

HASSE, Margareth. Biblioterapia como texto: análise interpretativa do processo biblioterapêutico. 2004. 124 f. Dissertação (Mestrado em Mestrado em Comunicação e Linguagens)-Universidade Tuiuti do Paraná, Curitiba, 2004.

Disponível em:<http://www.utp.br/proppe/edcient/Biblioteca> Acesso em: 1 set. 2008

HOLANDA, Nilson. Planejamento e projetos. Fortaleza: Universidade Federal do Ceará, 1982. 402p.

HORTA-TAVARES, Rosilene. Analfabetismo funcional versus aprendizagem qualificada: a importância da autonomia intelectual. In: CONGRESSO INTERNACIONAL ABED DE EDUCAÇÃO A DISTÂNCIA, 14., 2008, Santos. Anais... Santos: ABED, 2008.

IG EDUCAÇÃO. Universo escolar: como montar uma biblioteca. Disponível em: <http://klickeducacao.ig.com.br/2006/conteudo/pagina/0,6313,IGP-74-171,00.html> Acesso em: 1 jun. 2008. 
KOCHEN, M. The growth of knowledge: readings on organization and retrieval of information. New York: John Wiley e sons, 1983.

KUHLTHAU, Carol Collier. O papel da biblioteca escolar no processo de aprendizagem. In: VIANNA, Márcia Milton; CAMPELLO, Bernadete; MOURA, Victor Hugo Vieira. Biblioteca escolar: espaço de ação pedagógica. Belo Horizonte: EB/UFMG, 1999. p. 914.

LAR RITA DE CÁSSIA. Disponível em: <http://larritadecassia.vilabol.uol.com.br>. Acesso em: 20 out. 2008.

LE COADIC, Yves-francois. Ciência da informação. Brasilia: Briquet De Lemos/ Livros, 1996. $119 \mathrm{p}$.

LIMA, Etelvina. A criança e a biblioteca. Boletim de intercâmbio, Rio de Janeiro, v. 3, n. 12, p. 29-36, out./dez. 1982.

MACIEL. Alba Costa. Planejamento de bibliotecas: o diagnóstico. Niteroi: EDUFF, 1993. $91 \mathrm{p}$.

MARCINKO, Stephanie. Bibliotherapy: pratical applications with disabled individuals. Current studies in Librarianship, v. 13, n. 1/2, p. 1-5, Spring/Fall 1989.

MARTINS, Maria Helena. O que é leitura. São Paulo: Brasiliense, 1994. (Coleção Primeiros Passos, 74).

MELO, Maurizeide Pessoa de.; NEVES, Dulce Amélia de Brito. A importância da biblioteca infantil. Biblionline, v. 1, n. 2, 2005. Disponível

em:<http://www.biblionline.ufpb. br/Arquivos2/Arquivo6.pdf >. Acesso em : 21 abr. 2008.

MILANESI, Luís. A casa da invenção: biblioteca, centro de cultura. 4 ed. Cotia: Ateliê, 2003. 
NASCIMENTO, P. D.; LEITE, M. A. V.; OLIVEIRA, T. G.; et al. Brinquedoteca: psicoterapia corporal com crianças assistidas de um lar substituto. In: ENCONTRO PARANAENSE; CONGRESSO BRASILEIRO; CONVENÇÃO BRASIL LATINO/AMÉRICA DE PSICOTERAPIAS CORPORAIS, 9., 4., 1., 2004, Foz do Iguaçu. Anais... Foz do Iguaçu: Centro Reichiano, 2004.

OUAKNIN, Marc-Alain. Biblioterapia. Tradução Nicolás Niymi Campanário. São Paulo: Loyola, 1996.

PEREIRA, Marilia Mesquita Guedes. Biblioterapia: proposta de um programa de leitura para portadores de deficiência visual em bibliotecas públicas. Joao pessoa: UFPA, 1996. $105 p$

PORTO, Regina Maria Laclette; BRASIL, Maria Irene BIMM. Biblioteca Infanto-juvenil Maria Mazzetti 20 anos de atividades, 1979 / 1999. . In: CONGRESSO BRASILEIRO DE BIBLIOTECONOMIA E DOCUMENTAÇÃO, 19., 2000, Porto Alegre. Anais... Porto Alegre: Associação Rio Grandense de Bibliotecários, 2000.

Disponível em: <http://dici.ibict.br/archive/00000803/01/T150.pdf > . Acesso em 9 jun. 2008.

PRADO, Heloísa de Almeida. Organização e administração de bibliotecas. 2 ed. São Paulo: T. A. Queiroz, 1992.

QUEIROZ, Lisia de Melo, et al. Diagnóstico organizacional: um estudo empírico em micro e pequenas empresas de Uberlândia-MG. In: ASAMBLEA CONSEJO LATINO AMERICANO DE ESCUELAS DE ADMINISTRACION, 40., 2005, Santiago do Chile. 2005. Anais... Santiago do Chile: [s.n.], 2005. Disponível em:

<http://www.pablo.prof.ufu.br/artigos/cladea8.pdf>. Acesso em: 14 maio 2008.

QUINHÕES, Maura Esandola Tavares. Biblioteca Escolar: espaço de ação pedagógica. In: SEMINÁRIO NACIONAL - BIBLIOTECA ESCOLAR: ESPAÇO ESCOLAR: ESPAÇO DE AÇÃO DE PEDAGÓGIA, 2., 1999, Vitória. Anais... Vitória: Secretaria Municipal de Educação de Vitória, 1999.

RAMALHO, Márcia Terezinha de Borja. A brinquedoteca e o desenvolvimento infantil. 2000. 140 f. Dissertação (Mestrado em Engenharia de Produção)-Universidade de Santa Catarina, Florianópolis, 2000. 
RAMALHO, M. R. de B.; SILVA, C. C. M. da. A brinquedoteca. Rev. ACB: Biblioteconomia em Santa Catarina, v. 8/9, p. 26-34, 2003/2004.

RATTON, Angela Maria Lima. Biblioterapia. Revista da Escola de Biblioteconomia da UFMG, Belo Horizonte, v. 4, n. 2, p. 198-214, set. 1975.

REIMER, Everett. A escola está morta: alternativas em educação. Rio de Janeiro: F. Alves, 1979. $186 \mathrm{p}$.

ROSA, Aparecida Luciene Resende. As cartas de Ana Cristina César: uma contribuição para a biblioterapia. 2006. 84 p. Dissertação (Mestrado em Letras, área de concentração Linguagem, Cultura e Discurso)-Universidade do Vale do Rio Verde UNINCOR, Três Corações, 2006.

SALES. Fernanda de. O ambiente e a atuação bibliotecária: o olhar da educação e o olhar da Biblioteconomia. Enc. Bibli: R. Eletr. Bibliotecon. Ci. Inf., Florianópolis, n. 18, 2. sem. 2004

SANDRONI, Laura C.; MACHADO Luiz Raul. A criança e o livro: guia prático de estímulo à leitura. 3. ed. São Paulo: Ática, 1991. (Série Educação em Ação)

SANTOS, Dilaina Paula dos. Oficina de criatividade: adolescentes de orfanato apresentando novos contatos consigo e com o mundo. Inter.Ação.com, v.1, dez. 2002. Disponível em: <http://www.ciec.org.br/publicacoes_revista1.asp>. Acesso em: 29 ago. 2008.

SEPIN, Superintendência de Estatística, Pesquisa e Informação. Estatísticas municipais: séries históricas. Disponível em: <http://www.seplan.go.gov.br/sepin/>. Acesso em: 25 set. 2008.

SILVA FILHO, José Tavares da. Conservação de acervos: conservação preventiva de acervos bibliográficos. Urca, RJ: [s.n.], [200?].

Disponível em: <http://www.forum.ufrj.br/biblioteca/artigo.html> Acesso em: 1 jun. 2008

SONHAR ACORDADO. Disponível em: <http://www.sonharacordado.org.br>. Acesso em: 10 out. 2008. 
SPEZIA, Domingos. Modelo teórico das organizações: funções administrativas. Brasília, DF: UnB, 2007. Aula apresentada em 2/2007 na disciplina Organizações e Sistemas.

SUAIDEN, Emir. Biblioteca pública e informação à comunidade. São Paulo: Global, 1995. 112 p. (Coleção ciência da informação).

TARAPANOFF, Kira; SUAIDEN, Emir. Planejamento estratégico de bibliotecas públicas no Brasil: histórico, crise e perspectivas. Revista de Biblioteconomia de Brasília, v. 19, n. 2, p. 137-165, jul./dez. 1995.

TAVARES, Denise Fernandes. As bibliotecas infanto-juvenis de hoje. Salvador: Biblioteca Infantil Monteiro Lobato, 1970. 52 p.

A biblioteca escolar: conceituação, organização e funcionamento, orientação do leitor e do professor. São Paulo: LISA, 1973. 161 p.

VANIM, Mariléia; FAQUETI, Marouva Fallgatter. Elaboração de projetos. Camboriú: [s.n.], 2004. 5 p. Disponível em:<http://www.bu.ufsc.br/cac/projetos.pdf >. Acesso em: 31 maio 2008.

YUNES, E. A leitura e a formação do leitor: questões culturais e pedagógicas. Rio de Janeiro: Antares, 1984, p. 53. 
ANEXOS 


\section{Anexo A}

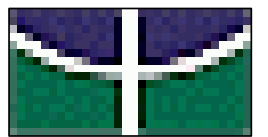

Universidade de Brasília

Faculdade de Economia, Administração, Contabilidade e Ciência da Informação e Documentação - FACE

Departamento de Ciência da Informação e Documentação - CID

Professora: Maria Alice Guimarães Borges

Mariana Giubertti Guedes

Neilia Barros Ferreira

\section{Questionário sobre o Orfanato Lar Rita de Cássia}

1.Como surgiu o orfanato?

2.De quem foi a iniciativa?

3.Quantos funcionários têm?

4.Atualmente, qual o número de crianças no orfanato?

5.Faixa etária delas?

6.Todas as crianças a partir de 7 anos estão na escola?

7.Em sua grande maioria, como é o desempenho escolar?

( ) insatisfatório

( ) regular

( ) satisfatório

( ) muito bom

8.É comum a repetência de série entre as crianças?

9.Como as crianças chegam ao orfanato?

10.Qual a idade mínima para entrar?

11.A idade máxima de permanência?

12.As crianças podem ser adotadas?

13.Vocês recebem ajuda financeira do governo?

14.Recebem algum outro tipo de ajuda?

15.Vocês têm renda própria?

16. Você acha interessante ter um local na biblioteca para as crianças brincarem?

17.Qual a sua opinião sobre o projeto de revitalização da biblioteca?

18.Tem alguma expectativa? Qual? 


\section{Anexo B}

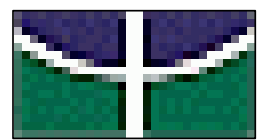

Universidade de Brasília

Faculdade de Economia, Administração, Contabilidade e Ciência da Informação e Documentação - FACE

Departamento de Ciência da Informação e Documentação - CID

Professora: Maria Alice Guimarães Borges

Mariana Giubertti Guedes

Neilia Barros Ferreira

Questionário: Projeto da Biblioteca

\section{Biblioteca}

1.Qual a História da Biblioteca? Vocês tem algum documento (histórico)?

2.Quantos $\mathrm{m}^{2}$ tem?

3.Quais são os mobiliários e equipamentos da biblioteca?

4.Do que é composto o acervo da biblioteca? E qual a quantidade?

5.Qual é o público da Biblioteca?

6.Como é feito a seleção dos documentos?

7. Como está organizado o acervo? O projeto de organização da biblioteca?

Criança x Biblioteca

8.Qual é a relação das crianças com a Biblioteca?

( ) não gostam

( ) indiferente

( ) gostam mas não usam porque está desorganizada

( ) gostam e usam mesmo desorganizada

9.Elas freqüentam outra biblioteca? Qual?

10.Elas demonstram interesse pela leitura?

11.Você acredita que os projetos da ONG incentivam a leitura?

12.A Hora do Conto trouxe algum benefício para as crianças? Qual?

13.Têm acesso a Internet? 


\section{Projeto}

14.A idéia de revitalizar a biblioteca surgiu:

( ) dos Administradores do Orfanato

( ) das Crianças

( ) dos próprios voluntários do sonhar acordado

( ) dos demais voluntários

( )

15.A revitalização da Biblioteca faz parte de qual projeto?

16.Esse projeto é bem aceito pela comunidade do orfanato?

17.0 valor dele comparado a outros projetos é prioritário?

18.O valor dele comparado a outros projetos da ONG é prioritário?

19.Qual a importância que o Projeto da Biblioteca trará para as crianças?

20.Em sua opinião, o que é fundamental para que esse projeto dê certo?

21.Qual sua expectativa quanto a revitalização da biblioteca?

22.É interessante para a Biblioteca ter uma brinquedoteca?

\section{Biblioteca e idéias para o projeto}

23.Essa biblioteca atenderá apenas as crianças do orfanato, ou existe alguma possibilidade de vir a atender o público externo?

24.Como deverá ser seleção dos documentos? Qual critério você acha que não pode faltar?

25.Como você pensa que o acervo deverá ser organizado para melhor atender o usuário?

26.Quais serviços você gostaria que a biblioteca oferecesse para as crianças até 6 anos?

De 7 a 14 anos?

E a partir dos 14 ?

27. O que você considera como a maior recompensa de fazer um trabalho voluntário como esse? 


\section{Anexo C}

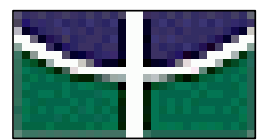

Universidade de Brasília

Faculdade de Economia, Administração, Contabilidade e Ciência da

Informação e Documentação - FACE

Departamento de Ciência da Informação e Documentação - CID

Professora: Maria Alice Guimarães Borges

Mariana Giubertti Guedes

Neilia Barros Ferreira

\section{Questionário: Perfil do usuário}

Qual seu nome?

Sexo?

Idade?

Você está cursando qual série na escola?

Você gosta de ler?

( ) não

( ) um pouco

( ) gosto

( ) mais ou menos

( ) gosto muito

O que você prefere ler?

( ) romance

( ) ficção

( ) policial

( ) aventura

( ) gibi

( ) mangá

( ) revista informativa ( veja, istoé, etc..)

( ) revista de entretenimento ( caras, capricho, tititi, etc...)

O que você ler com mais freqüência?
( ) livros da escola
( ) literatura
( ) jornais
( ) revistas
( ) Gibi
( ) Mangá

Quantos livros você esse ano? Exceto os obrigatórios da escola.
( ) dois
( ) cinco
( ) três
( ) mais de cinco
( ) quatro

Na sua escola tem biblioteca?
( ) não
( ) $\operatorname{sim}$
( ) não sei 
Você usa a biblioteca da sua escola?
( ) não
( ) $\operatorname{sim}$

Você usa a biblioteca do Orfanato?
( ) não
( ) $\operatorname{sim}$

Se sim, o que você costuma fazer lá?

( ) pesquisa para a escola

( ) pegar ou ler livros

( ) estudar

( ) pegar ou ler Gibi

( ) outros

Se não, qual é o motivo?

( ) não tem interesse

( ) nunca precisou usar

Você já usou a Internet?
( ) não
( ) $\operatorname{sim}$

Se não, tem interesse em usa?
( ) sim
( ) não

Se sim, com qual finalidade?
( ) Ter informação
( ) pesquisar
( ) visitar sites de relacionamentos
( orkut, etc..)

( ) jogar
( ) ver charges
( ) visitar Blogs
( ) visitar Chats 